1998

\title{
Early Secondary Succession in the Bottomland Hardwood Forests of Southeastern Virginia
}

David Randolph Spencer

College of William and Mary - Virginia Institute of Marine Science

Follow this and additional works at: https://scholarworks.wm.edu/etd

Part of the Ecology and Evolutionary Biology Commons

\section{Recommended Citation}

Spencer, David Randolph, "Early Secondary Succession in the Bottomland Hardwood Forests of Southeastern Virginia" (1998). Dissertations, Theses, and Masters Projects. Paper 1539617740.

https://dx.doi.org/doi:10.25773/v5-m05s-e235

This Thesis is brought to you for free and open access by the Theses, Dissertations, \& Master Projects at W\&M ScholarWorks. It has been accepted for inclusion in Dissertations, Theses, and Masters Projects by an authorized administrator of W\&M ScholarWorks. For more information, please contact scholarworks@wm.edu. 
EARLY SECONDARY SUCCESSION IN THE BOTTOMLAND HARDWOOD FORESTS OF

SOUTHEASTERN VIRGINIA

\begin{abstract}
A Thesis
Presented to

The Faculty of the School of Marine Science

The College of William and Mary in Virginia
\end{abstract}

In Partial Fulfillment

Of the Requirements for the Degree of

Master of Science

by

David R. Spencer

1998 


\section{APPROVAL SHEET}

This thesis is submitted in partial fulfillment of the requirements for the degree of

Master of Science

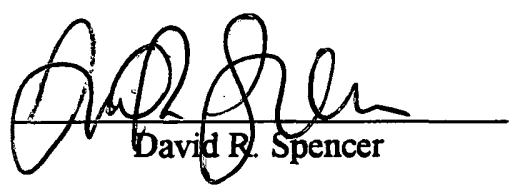

Approved, April 1998
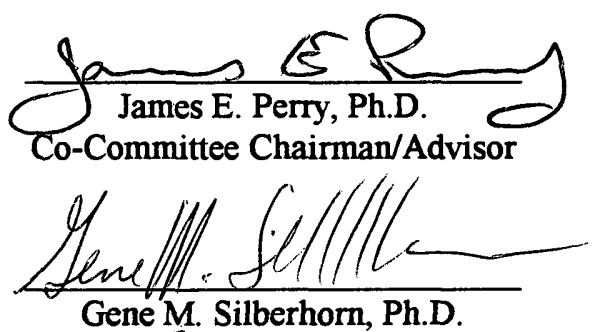

Co-Commttee Chairman/Advisor

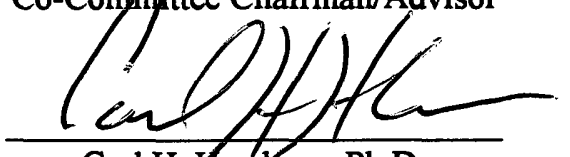

Carl H. Kershiner, Ph.D.

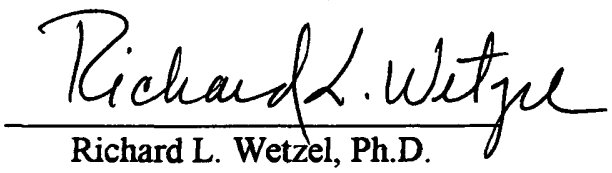

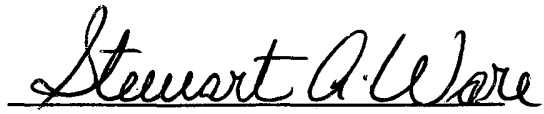

Stewart A. Ware, Ph.D.

College of William and Mary

Williamsburg, Virginia 
LIST OF TABLES

LIST OF FIGURES.

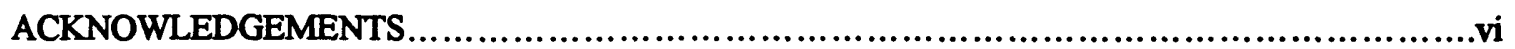

ABSTRACT

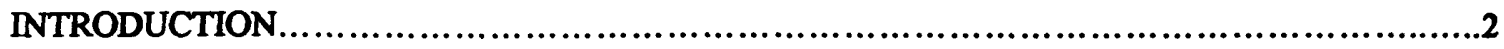

LITERATURE REVIEW

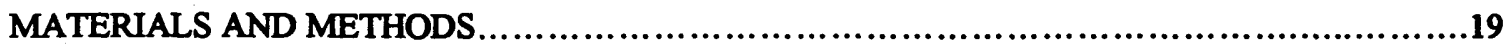

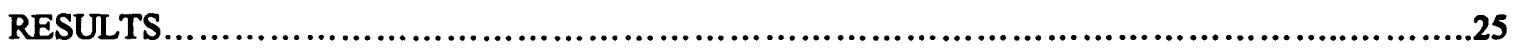

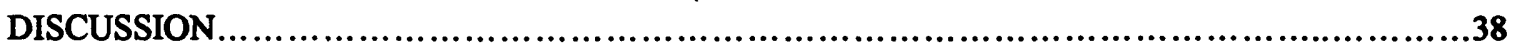

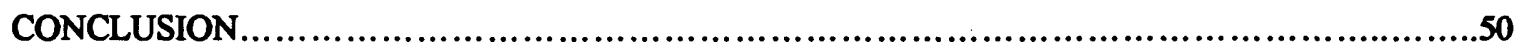

LITERATURE CITED

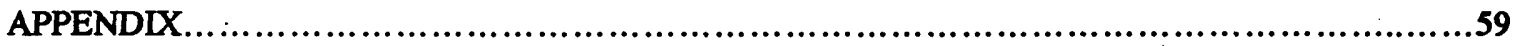

VITA 


\section{List of Figures}

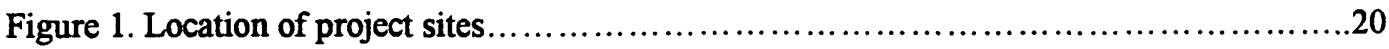

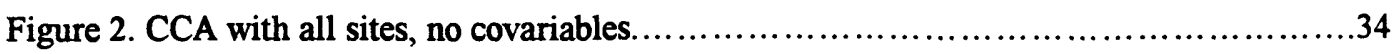

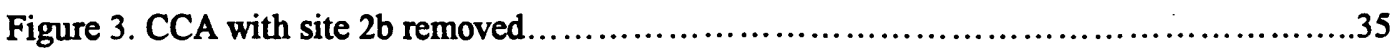

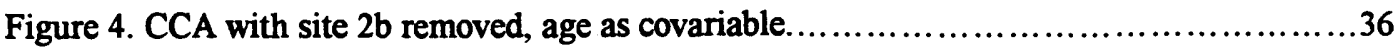

Figure 5. Conceptual model of early secondary succession................................47 


\section{List of Tables}

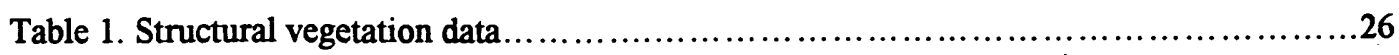

Table 2. Importance values of overstory species......................................28

Table 3. Importance values of understory species........................................29

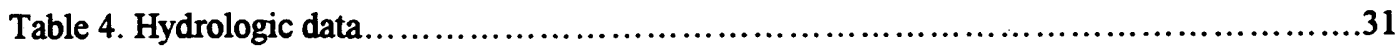

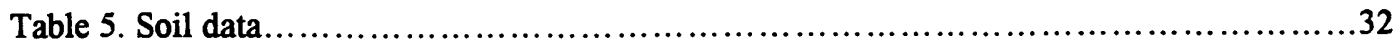




\section{Acknowledgments}

I would like to express my extreme gratitude to Dr. James Perry for providing me the opportunity to undertake this project, as well as the intellectual and financial support necessary to reach this longawaited conclusion. I would also like to thank Jim and his wife, Lorraine, for their willingness to go far out of their way to make the VIMS experience a positive one, not just for myself but for any student fortunate enough to make their acquaintance. However, I still have nothing good to say about the peacock.

The assistance of the other members of my committee is also much appreciated, particularly that of Carl Hershner, who has done far more for me than I could ever possibly recognize in this short space.

Many thanks go out to Amanda Meuller, Rebecca Smith, Rose Laird, and Michael Campana for their considerable help with field work, which required that they drive thousands of miles across southeastern Virginia and endure intense heat, bitter cold, relentless sun, pounding rain, deep swamps, deerflies, mosquitoes, chiggers, and ticks. I know... the brochure that came with my application never mentioned any of that stuff either.

I would suffer eternal bad karma if I did not also mention the folks in the Coastal Inventory trailer, who were kind enough to let me have a little corner of their castle on cinder blocks, and my family, both in South Carolina and Virginia, who provided everything else I needed.

This project would not have been possible without the assistance of Union Camp Corporation, who assisted in the location of sites and allowed us access to their land, and the Virginia Department of Forestry, who assisted in the location of privately owned sites. My utmost gratitude is also extended to the private landowners that were kind enough to permit our intrusions on their land and to the deer hunters of southeastern Virginia for never even once trying to shoot us.

This project was funded by a grant from the Environmental Protection Agency. 


\begin{abstract}
With losses of bottomland hardwood forests in the southeast continuing to be problematic, efforts to minimize the net loss of ecological and societal functions remain focused on the creation or restoration of similar habitats. In order to provide a manageable protocol for monitoring the success of bottomland hardwood mitigation sites, emphasis is now being directed towards establishing "reference" sites that are representative of regional and local conditions. However, the time period over which created or restored bottomland hardwoods begin to resemble natural systems is more on the order of decades rather than years, much longer than the average permit applicant could be expected to monitor a mitigation site. This project examines the early successional properties of a chronosequence of seventeen forested wetlands that have been clearcut and allowed to naturally revegetate. Density and either cover or basal area of vegetation were measured in each of three strata. Relative hydrology was established through the installation of monitoring wells and soil was analyzed for $\mathrm{pH}$, organic matter content, and cation exchange capacity. Ordinations performed on the data using CANOCO software indicated three general types of communities - one dominated by bald cypress (Taxodium distichum) and water tupelo (Nyssa aquatica), one dominated by black willow (Salix nigra), and one with a species composition similar to that of a mature stand of bottomland hardwoods. These divisions were correlated with the percentage of stems originating as coppice on stumps leftover from the clearcut. In particular, the bottomland hardwood stands were regenerating predominantly as coppice, while the cypress/tupelo and black willow stands were regenerating primarily as seedlings. As indicated by the earlier development of overstory basal area, coppice sites were also regenerating much faster. The hydrology of a site also exhibited a strong impact on the rate of regeneration, with the semi-permanently to permanently flooded portions of sites often exhibiting little or no regeneration. The results indicate that, because of the overwhelming reliance on coppice sprouts as the main source of stems and the concomitant enhanced rates of regeneration, certain vegetative parameters of clearcut bottomland hardwood stands would not be effective benchmarks by which to judge the relative success of creation and restoration efforts. Exceptions might include bottomland hardwood mitigation sites that have been colonized by black willow, as well as created or restored cypress swamps where the substrate contains a viable seed source and a natural physical regime is present.
\end{abstract}

Keywords: bottomland hardwood forest, wetland, clearcut, reference, restoration, monitoring, succession, mitigation, vegetation 
EARLY SECONDARY SUCCESSION IN THE BOTTOMLAND HARDWOOD FORESTS OF SOUTHEASTERN VIRGINIA 


\section{Introduction}

Bottomland hardwood forests, often referred to elsewhere as palustrine forested wetlands (Cowardin et al. 1979) or southern floodplain forests (Kuchler 1964), are a dominant landscape feature across the southeastern United States. Among the various types of wetlands found in the United States, these ecosystems have historically suffered disproportionately large losses, primarily through agricultural conversion, with draining and clearing of forested wetlands beginning in earnest around the mid-1800's and accounting for average annual losses of approximately 165,000 acres per year between 1940 and 1975. Although the push towards agricultural conversion has slowed somewhat in recent years, the losses associated with development pressures have since increased dramatically and the net loss of bottomland hardwoods continues to be problematic (Harris and Gosselink 1986, Gosselink and Lee 1987, Tiner et al. 1994).

While federal, state, and local governments have attempted to stem the tide of wetland loss through an assortment of direct and indirect legislative efforts, Section 404 of the Clean Water Act remains the cornerstone of protection for threatened bottomland hardwood systems in the United States (Muir et al. 1990). While not expressly written as a wetlands protection law, this powerful legislation mandates that anyone seeking a U.S. Army Corps of Engineers permit to fill wetlands provide compensatory mitigation for any unavoidable impacts. Compensatory mitigation is defined in 40 CFR 1508.20 (e) as "compensating for the impact by replacing or providing substitute resources or environments," and is considered by the Corps of Engineers to include preservation, enhancement, restoration, or creation of wetlands.

Although the standards dictated by the Clean Water continue to remain controversial, the creation and restoration of wetlands has nevertheless been a growth industry in recent years as permit applicants seek to avoid the project constraints associated with avoidance and 
minimization of wetland impacts. Based on the premise that wetlands perform critical ecological and societal functions, these efforts are undertaken with the intention of minimizing the net loss of these functions within the impacted ecosystem (Mitsch and Gosselink 1993).

Currently, however, the science upon which compensatory mitigation projects are based is still in its relative infancy and there remain serious questions concerning the potential for successful recreation of bottomland hardwood systems. In an effort to ensure the effectiveness of creation and restoration efforts, regulators often require monitoring of mitigation sites as a condition of project authorization. In the case of freshwater and saltwater marshes, colonization and succession of plant communities is fairly rapid and the degree of success attained can generally be ascertained within a few years (Landin and Webb 1986). On the other hand, the time frame over which created or restored bottomland hardwoods begin to resemble natural systems is more on the order of decades rather than years (Kusler 1986, Mitsch and Gosselink 1993), much longer than the average permit applicant could reasonably be expected to monitor a mitigation site and, for that matter, much longer than the institutional memory of the regulatory agencies charged with seeing that mitigation requirements are met (Clewall and Lea 1990).

Thus, in order to provide a manageable protocol for monitoring of bottomland hardwood mitigation sites, emphasis is now being directed towards the establishment of "reference wetlands" that are representative of regional and local conditions (Mitsch and Gosselink 1993, Clewall and Lea 1990, Erwin 1990, Brooks and Hughes 1986). The concept of reference wetlands has become increasingly familiar to wetland professionals during recent years with the ongoing development of the hydrogeomorphic functional assessment method (HGM) (Brinson 1993, Brinson and Rheinhardt 1996, Rheinhardt, Brinson, and Farley 1997). In the HGM methodology, reference wetlands are selected to represent a range of ecological conditions, from pristine (assumed to represent the highest level of functioning) to disturbance-mediated, within a 
defined wetland class and geomorphic setting. Field parameters from these sites are used to determine reference standards which, in turn, allow development of a model of the wetland functions performed by that particular class of wetlands. The model quantifies the loss of functions associated with wetland impacts, as well as the recovery of functions when wetlands are created or restored, providing a defensible method of determining a ratio between acres impacted and acres compensated that is consistent with the goal of no net loss of wetland functions (Brinson and Rheinhardt 1996).

While the process of developing reference wetlands pursuant to HGM methodology accounts for many of the spatial, temporal, and environmental gradients that influence the functions performed by bottomland hardwood systems, it must be realized that this procedure does not provide a means of estimating the developmental trajectory of forested wetland systems during the earliest stages of succession. These first few years, however, represent the time period during which most creation and restoration projects are monitored for success. Thus, there is an need for data on these early successional processes (Allen 1997) that can be used as a benchmark to indicate whether these compensatory wetlands are indeed proceeding towards a mature system that will adequately replace the functions previously performed by the impacted wetland.

The purpose of this project was to examine a suite of naturally revegetated forested wetlands and to quantify early secondary succession in the bottomland hardwood forests of southeastern Virginia. This was carried out by conducting vegetation analyses on a chronosequence of seventeen sites that were clearcut over the last two to twenty years and allowed to naturally revegetate. In order to more closely approximate the natural successional changes following timber harvest, sites were selected based on the presence of an unimpacted hydrologic regime and the lack of artificial treatments, such as seeding, burning, or use of chemicals. Species composition was not a determining factor in the site selection process, as this 
was expected to be one of the factors influencing successional trajectory and would have thus biased the results of the study.

During the site selection phase of this study, it was evident that the most readily discernible and dramatic differences between early successional sites would be related to their structural characteristics (i.e. the amount of herbaceous vegetation, overstory development, etc.). The challenge, then, would be to identify any edaphic, biotic, or hydrologic factors that maintain an overriding influence on the rate of change of structural composition. Although there is relatively little information available regarding the initial pulse of regeneration following timber harvest, both documented and anecdotal accounts indicate the importance of coppice sprouts to the rapid development of an overstory (B. Heeren, pers. comm.). Also noted as influencing the productivity of forested wetlands is the hydrologic regime and the associated flow of nutrients through a site, with primary productivity peaking where there is a pulsing hydroperiod (Taylor et al. 1990). Thus, it was hypothesized that the data would indicate successive dominance of structural components, from herbaceous to woody understory to forest vegetation as time progresses. Dominance of particular species and structural components at a given age was expected to be correlated with hydrologic regime and the availability of stumps for coppice sprouting, and to a lesser extent soil characteristics and other environmental variables. In particular, the presence of extensive coppice regeneration was expected to accelerate the early development of an understory, while regeneration was expected to be stunted in those sites characterized by a stagnant hydrology with continuous or nearly continuous inundation. The data gathered in this study is intended to provide the foundations of a database that will assist regulators in the establishment of achievable goals for the creation and restoration of bottomland hardwoods in southeastern Virginia, as well as an objective means of evaluating the relative success or failure of these efforts. 


\section{Literature Review}

\subsection{Succession in General}

Warming (1909), Moss (1910), Braun, and Furrer (Braun and Furrer 1913) represent just a few of the many early plant ecologists concerned with the processes of formation and association in plant communities; among these, however, F.E. Clements has consistently proven to be among the most influential (van der 'Valk 1982). Clements (1916) summarized succession research dating back to 1685 and then proceeded to develop a model of the dynamics of natural vegetation. This model sought to describe succession as a function of six basic processes: nudation, migration, ecesis, competition, reaction, and stabilization. Nudation, or the creation of bare patches of soil, is traditionally considered the beginning of succession and is followed by colonization of the area by migrating propagules or propagules already contained in the soil. Environmental conditions initially control the successful establishment of plant species, or ecesis, after which competition for limited resources eliminates some species and favors others. As plants grow and die, changing environmental conditions affect the availability of resources and is thus reflected by the reactions of plant communities to these changes. Stabilization, the final stage of Clementsian succession which rarely occurs, is manifested in the domination of a site by very long-lived and self-reproducing species.

While the above listed processes are still extremely relevant to any discussion of successional theory, it is Clements' further assertion that all succession moves towards a stable, self-reproducing terrestrial community in equilibrium with the regional climate that continues to draw criticism from plant ecologists. This approach has often been interpreted as a gross simplification in which all wetland vegetation exists as a series of relatively short-lived stages, 
eventually leading to a terrestrial climax community (van der Valk 1982). Clements merely described the situation in which development of a climax community is halted indefinitely as a sericlimax and pointed specifically to the cypress-gum swamps as an example (Weaver and Clements 1938).

The first major theoretical departure from Clements' concept of succession was developed by Gleason $(1917,1927)$. Gleason's theory, known as the individualistic concept of plant association, argues against the existence of a climax community per se, and instead emphasizes the importance of migration and environmental selection to the propagation of individual species in a given area. Basically, he is implying that disseminules migrate everywhere, growing where favorable environmental conditions exist until these conditions no longer occur, and rendering the survival of any given species subject to the limitations of the environmental gradients it is able to endure. Thus, vegetative "communities" are actually nothing more than a conglomeration of species able to survive under similar environmental conditions.- As conditions change, either spatially or temporally, some species can no longer endure while new ones are able to propagate, making it impossible to rigidly define the scope or extent of a plant association. Lacking this definition, plant associations can not be logically grouped into larger classifications representative of the successional series suggested by Clements (Gleason 1927).

Despite frequent criticism of the assumptions made by Clements, the underlying principles of his theory have remained pervasive in discussions of ecological succession throughout most of this century. Odum (1969), for example, based his holistic theory of ecosystem development on three parameters that closely parallel Clements' ideas: (1) succession is an orderly process of community change that is reasonably directional and therefore predictable; (2) it is community controlled in that it results from modification of the physical 
environment by the community; and (3) it eventually culminates in a stabilized ecosystem. Odum differs somewhat in that he relates his conclusions more in terms of the biomass of the system, rather than the particular species present.

Over the past two decades, however, a substantial number of articles have been explicitly critical of the Clementsian theory of succession (McCormick 1968, Drury and Nisbet 1971, Horn 1974, 1975). Connell and Slayter (1977) provides a review of the theory and the evidence supporting it, and go on to propose two alternative models. Facilitation, the Clementsian model, is said to lack supporting evidence and to have been deduced from the concept that the mature community is in steady state and maintained by internal feedback control mechanisms, although it is conceded that the mechanisms determining community development may apply to heterotrophic successions and certain primary successions. The tolerance model describes succession as a process by which the combination of species that most efficiently exploits the different kinds or proportions of resources eventually dominates the community. Several examples are given to support the assertion that, in dense light-limited forests, the species able to grow on the lowest level of resources will dominate the community at equilibrium; however, in the examples the forests are apparently replacing themselves by vegetative reproduction (root sprouts) rather than by independant offspring (seedlings). The final model, inhibition, occurs where there exists no competitively superior species, so whichever colonizes the site first maintains their position against all comers save those that bring along or create their own resources. This leaves damage and death as the only means by which replacement occurs, which results in a gradual shift in species composition towards those that live longer and removes the directional mechanisms present in the first two models in deference to basic life-history characteristics. 


\subsection{Succession in Wetlands}

Early studies of wetland succession dealt primarily with the zonation of vegetation around lakes in England and the United States and were predominantly influenced by Clementsian theories of successional communities (Pearsall 1920, Gates 1926, Wilson 1935). Wilson (1935) describes the progressive development of seepage lakes in Wisconsin as occurring in a series of steps by which the lake is isolated from a drainage system, the bays are isolated from the main body of water smoothing the outline of the lake, and organic sediments accumulate to the point that the plant community begins to change from one type to another. Gates (1926) takes this one step further by asserting that zonation of vegetation around lakes directly represents the successional processes underway at a given time and that lakes will eventually fill and resemble the surrounding upland community. Other historical studies of succession in wetlands have dealt primarily with vegetation changes occurring after drawdowns of impoundments in the interest of managing the impoundments for optimum waterfowl conditions (Harris and Marshall 1963, Meeks 1969).

More recently, van der Valk $(1981,1982)$ has introduced the concept of a Gleasonian approach to succession in wetlands. He constructs a model of succession in temperate North American wetlands in which vegetation changes are a function of environmental conditions and life history characteristics of species present. The wetland environment is said to act as a sieve, regulating the establishment of species through changing water levels. Recognizing the paucity of information available on the majority of wetland species, van der Valk has limited his model to allogenic succession, rather than general succession, based on three key life-history features: life-span, propagule longevity, and propagule establishment requirements. Species are classified as being either annuals, perennials, or vegetatively reproducing perennials with an indefinite life 
span; as dispersal-dependent species with short-lived propagules or seed bank species with longlived propagules; and, as drawdown species that can become established only in the absence of standing water or standing-water species that can get established when there is standing water, respectively. The result is a qualitative model that predicts only which species will be present, with no information provided as to their relative abundance, and that fails to include the effects of interactions among plants which are potentially significant in determining presence or absence.

\subsection{Succession in Bottomland Hardwood Forests}

Very little research has been specifically directed at quantifying the early successional vegetation dynamics of forested wetlands. In one of the more recent attempts, Johnson et al. (1985) examined vegetation succession on newly formed islands in the Atchafalaya River delta. They conclude that the environmental factors varying most consistently with plant associations are the physical factors dependent on hydrologic regime, namely percent variation in water level, organic carbon, and percentage sand, while little correlation was observed between plant associations and soil mineral content. It should be noted, however, that this study examines primary succession as opposed to secondary succession. According to Tilman (1988), primary succession generally begins as a bare mineral substrate, perhaps following sand dune formation, glacial recession, volcanic eruption, or major erosion; whereas secondary succession occurs on substrates where organic soil and the propagules of various plant species are present at the outset, as is the case after abandonment of farming or clearcutting.

Bowling and Kellison (1983) examined secondary succession in the twenty-two years following clearcutting of a bottomland hardwood forest in Mississippi. Their results challenge 
the traditional notion among hardwood silviculturalists that the oak component of a regenerated stand will not be present if advance oak reproduction was not present in the preceding stand. While early regeneration in the study site was dominated by ironwood (Carpinus caroliniana) and sweetgum (Liquidambar styraciflua), with oak comprising a relatively minor constituency, by age 19 oak had outcompeted the shade-tolerant ironwood to become the dominant species along with sweetgum. Bowling and Kellison results support their contention that a desirable species composition is attained when a stand is clearcut and allowed to naturally regenerate. Mentioned but not addressed directly was the prolification of coppice sprouts on the project sites and their role in the early successional structure of bottomland hardwood forests. Coppice, which refers to stems originating from the cut stumps or following harvest, was identified more recently in a study by Messina et al. (1997) as accounting for $83 \%$ of the stems in a Texas bottomland hardwood forest in the years immediately following a clearcut.

Clearcutting, in fact, is considered by most experts to be the best method for harvesting bottomland hardwood forests in terms of providing for successful regeneration (Stubbs 1973, McKnight and Johnson 1975, Heeren 1983). In a study of woody plant regeneration following timber harvest by helicopter and by rubber-tired skidder, Mader (1990) quantified changes in plant community structure, noting in particular total standing biomass, habitat suitability, and species richness. Within two years plant productivity had reached approximately seventy percent of that in an undisturbed reference forest, propelled mostly by rapidly growing herbaceous vegetation and stump sprouts. The rapid recovery of plant productivity and other wetland functions, such as nutrient retention, prompted the conclusion that clearcutting forested wetlands is an acceptable and, indeed, preferable forestry management practice. Conner (1994) pointed out that the primary causes of species composition changes in timbered wetlands have been the selective cutting of bald cypress (Taxodium distichum), often leading to dominance by water 
tupelo (Nyssa aquatica), and modification of the natural hydrologic regime. Contrary to Mader (1990), Gresham (1985) argued that species composition and spatial distribution three years after a clearcutting of a forested wetland in the coastal plain of South Carolina is unacceptable and recommends the postharvest planting of seeds or seedlings.

In a study of woody plant regeneration in four closed-canopied floodplain forests, Jones et al. (1995) noted the following: (1) smaller-seeded species comprised a dominant proportion of seeds and germinants; (2) survival rates were greater for species germinating early in the growing season; (3) survival rates for seedlings increases during the first several growing seasons; (4) seedlings growing near conspecific adults experienced reduced survival rates; and, (5) dense understory seedling pools were established as a result of slow growth of seedlings.

\subsection{Wetland Functions}

Taylor et al. (1990) outlined four interdependent classes of functions typically present in bottomland hardwood systems. The first includes those functions related to community dynamics: (a) primary production, which is estimated to range from 700 to nearly $1800 \mathrm{~g} \mathrm{C}^{2} \mathrm{~m}^{2} / \mathrm{yr}$ depending in part on hydrology and vegetation (Brinson et al. 1981), (b) the decomposition of litterfall through leaching of soluble materials, mechanical fragmentation, and biological decay, (c) the export of organic detritus to support aquatic food chains, and (d) the provision of habitat for a diverse array of aquatic and terrestrial organisms. Second, physiochemical processes, which are mediated largely by the velocity and volume of water in the wetland and the amount of sediment it carries, include the deposition of sediments as streamwater flows across the floodplain, the bioassimilation of nutrients and pollutants contained in surface runoff, and a myriad of biochemical transformations. Third, surface water storage refers to the capacity of 
wetlands to retain pulses of water associated with spring runoff and storm events. Finally, the ability of some floodplain wetlands to recharge both surficial and deep aquifers through percolation of surface water, and of others to discharge groundwater during low-flow periods, comprises the groundwater storage class of functions.

When these functions are considered in light of their ability to meet current human needs, their economic value to society becomes readily apparent. This has in turn led various researchers to attempt quantification of particular values, such as flood mitigation and control, biomass production, and even visual-cultural qualities (Johnson and Linder 1986, Farber and Costanza 1987, Costanza et al. 1989). For example, it has been estimated that loss of the 3,400 hectares of wetlands in the Charles River Basin, Massachusetts, would increase annual flood damages by approximately $\$ 17$ million (U.S. Army Corps of Engineers 1972 in Mitsch and Gosselink 1993).

\subsection{Analytic Methods - Community Structure}

Although there are no standardized methods for analyzing the community structure of bottomland hardwood forests, most studies are similar in that they examine the density and dominance of species according to specific vegetative classes based on height, stem diameter, and other physiognomic characteristics. These classes can include, but are not limited to, overstory, understory, trees, saplings, seedlings, shrubs, vines, and herbaceous plants. The divisions between the respective classes are often rather arbitrary, varying significantly with the vegetative composition of the study site as well as the objectives of a particular study. Frequently in studies of swamp community structure, overstory has included those trees greater than $2.5 \mathrm{~cm}$ diameter 
breast height (dbh) (Day 1984, Fowler 1987, Silberhorn 1992), although this cutoff is by no means consistent throughout all studies of the forested wetlands of the mid-Atlantic region (Doumlele et al. 1985, Pavel 1993, Rheinhardt 1991).

Analyses of forest vegetation frequently employ quadrat methods, in which the investigator determines densities and basal areas of plants rooted within a circular or rectangular plot (Meuller-Dombois and Ellenberg 1974), as well as a variety of somewhat more efficient plotless techniques which, generally speaking, determine the same parameters through the use of variable radius circular plots (Bitterlich 1948, Grosenbaugh 1952, Meuller-Dombois and Ellenberg 1974) or by calculating distances between plants (Cottam and Curtis 1956, MeullerDombois and Ellenbergh 1974). One particular distance method, the point-centered quarter technique (Cottam and Curtis 1956) has proven to be particularly effective in studies of swamp community structure (Fowler 1987, Doumlele et al. 1985). This technique, however, suffers the same limitation as other distance techniques in that it assumes a random distribution of plants (Meuller-Dombois and Ellenberg 1974) which, given the preponderence of coppice regrowth and aggregations of seedings in timbered wetlands, is not a valid assumption for young ecosystems of this type. Therefore, studies of forested wetland regeneration have tended to utilize the variety of quadrat methods available (Huenneke and Sharitz 1986, Mader 1990, Pavel 1992).

Evaluation of the herbaceous communities of forested wetlands involves the use of similar, albeit smaller, quadrats. Rather than measuring basal area to determine dominance, cover, or the vertical projection of the crown or shoot area of a species onto the ground, is estimated as a fraction or percent of the quadrat area (Meuller-Dombois and Ellenberg 1974). This can be accomplished directly through point-intercept methods, although these are often time-consuming and difficult to implement properly (Meuller-Dombois and Ellenberg 1974). More frequently, percent cover is visually estimated for each species in each quadrat, then ranked 
and averaged according to a cover class scale comprised of a series of ranges of percentages (Meuller-Dombois and Ellenberg 1974). Although the differences between available cover class scales are minimal (Meuller-Dombois and Ellenberg 1974), several recent studies have employed a modified Daubenmire technique (Daubenmire 1959, 1966, 1968) to assess terrestrial and wetland plant communities of the mid-Atlantic coastal plain (Levy 1976, Levy et al. 1984, Perry 1991, Rheinhardt 1991).

\subsection{Statistical Methods}

Data gathered during field studies of plant community structure tends to be bulky and rather complex, complicating efforts to identify any correlations or relationships that may exist. Multivariate statistical methods, which allow examination of numerous variables simultaneously, provide useful techniques for summarizing the data and elucidating any structure that may exist (Gauch 1982). Austin (1977) suggests that multivariate methods can be particularly effective for describing the temporal changes in vegetation associated with succession and for demonstrating interactions between spatial patterns of environment and vegetation over time.

Among the many multivariate statistical analyses available, ordination techniques are widely used to summarize plant community data. They do so by reducing large data matrices (usually consisting of species and stands) into a low-dimensional space with proximity of data points corresponding to similarity (Gauch et al. 1977, Causton 1988). The primary methods of ordination include Bray-Curtis (Bray and Curtis 1957), principal components analysis (Goodall 1954, Orloci 1966), reciprocal averaging (Hill 1973), and detrended correspondence analysis (Hill and Gauch 1980). Principal components analysis was one of the earliest ordination techniques, yet one still commonly used to examine a variety of types of data. It is a non-polar 
ordination method that establishes axes by considering maximum variation of the stand set as a whole, rather than basing them on pairs of very dissimilar stands as in polar ordination (Causton 1988). It has the advantages of accommodating many types of data and of being an especially objective ordination technique in that it requires no weighting of data or selection of endpoints (Gauch 1977). However, principal components analysis is problematic in that the mathematic model on which it is based requires the investigator to make unrealistic assumptions about the normality of ecological data, which then produces an arch effect when plotted in two dimensions that is typically not a reflection of any ecological attribute of the data (Causton 1988).

The effectiveness and accuracy of principal components analysis has been questioned by several authors who performed a variety of prominent ordination techniques on identical data sets, both actual and simulated (Gauch and Whitaker 1972, Beals 1973, Kessell and Whitaker 1976, Gauch et al. 1977). Gauch et al. (1977) compared principal components analysis to reciprocal averaging and Bray-Curtis ordination. Reciprocal averaging is a weighted averaging technique, the main advantages of which are simultaneous ordering of sites and species, rapid computation, and robustness despite nonlinear and unimodal relationships to environmental gradients, which has been a problem for principal components analysis (Palmer 1993). While reciprocal averaging was generally found to be superior to principal components analysis, it is still subject to a pronounced arch effect in the second axis and accuracy deteriorates when outlier samples are included in the analysis. Also, reciprocal averaging has a tendency to obscure discontinuities in the data set by compressing data onto the first axis (Beals 1984). Interestingly, Gauch et al. (1977) found that the most robust of the techniques was the Bray-Curtis ordination, which is not subject to an arch effect or distorted by clusters of samples and outliers.

The polar ordination method was devised by Bray and Curtis in the 1950's for the purpose of understanding the complex interactions of environmental and vegetative factors over 
gradients, as opposed to the non-polar ordination methods which were not designed specifically for ecological data (Gauch 1977). It requires the computation of percent dissimilarity between stands and, based on this, the selection of the two most dissimilar stands as endpoints, or poles, of the ordination axis. Gauch and Whitaker (1972) and Beals (1984) recommend Sorensen's coefficient of community rather than the Czekanowski (percentage similarity) variant first used by Bray and Curtis. Provided that an outlier is not selected as one of the endpoints, this method of ordination consistently provides results as good as or superior to those provided by the mathematically more rigorous methods mentioned above (Gauch and Whitaker 1972, Beals 1973, Kessell and Whitaker 1976, Gauch et al. 1977).

Habeck (1968) used Bray-Curtis ordination to examine secondary succession in the cedar-hemlock forests of Glacier National Park. A total of 78 quantitative characteristics, including importance values of trees, saplings, and seedlings, as well as quadrat frequencies for common understory species, were included in the ordination of 33 stands ranging in age from approximately 50 to 400 years old. Due to the environmental homogeneity of the study area, a single axis was sufficient to describe compositional change with time, whereas a more variable environment would have required that a multidimensional ordination be performed. The results firmly supported earlier qualitative analyses of the same area and corresponded to recorded changes in structural properties, such as reduced densities of trees over time.

A later modification of reciprocal averaging known as detrended correspondence analysis (DCA) (Hill and Gauch 1980) was designed to correct the relationship between the first and second axes that produces the arch effect. One of the most widely used ordination techniques, DCA is an indirect gradient analysis, meaning that environmental gradients are inferred from species data, rather than studied directly. While the detrending step successfully accomplishes the objective of eliminating the arch effect, Palmer (1993) points out that the 
improved method fails to account for the information lost when data is compressed onto the first axis and that, like its predecessor, it is significantly affected by rare species or outlier samples.

More recently, another variation of reciprocal averaging, canonical correspondence analysis (CCA), has gained considerable prominence. Based largely on the work of Ter Braak $(1985,1986,1988)$, CCA differs from DCA in that it is a direct gradient analysis, directly and immediately relating species composition to measured environmental variables (Palmer 1993). In a comparison between CCA and DCA using simulated data, Palmer (1993) described CCA as "having all of the advantages and none of the disadvantages of CCA.." Specifically, the arch effect appeared only when there existed a true arch in the data and results did not appear to exhibit the compression of data points that produces the "tongue effect" in other reciprocal averaging techniques. CCA is also capable of performing a technique known as partial ordination, in which covariables representing site-to site environmental variation are factored out of the ordination. The procedure thus minimizes the effect of covariables on the outcome of the ordination $_{2}$ and does so with no major distortion of the grid (Palmer 1993). 


\section{Methods}

\subsection{Study site}

The field work for this research took place in the watersheds of the Blackwater, Nottoway, and Meherrin rivers, which together form a considerable portion of the Chowan River Basin in southeastern Virginia and northeastern North Carolina. Sites were located in the upper coastal plain, an area that has an average frost-free period of approximately 200 days (Plunkett and Hall 1995) and receives approximately 48 inches of rain per year, mostly between April and September. Predominant land uses in the region include silviculture and agriculture, with corn, cotton, peanuts, and soybeans representing the main crops.

Seventeen sites, as shown in Figure 1, were selected for inclusion in this study, all of which are owned either by Union Camp Corporation or by private citizens who manage their land in coordination with the Virginia Department of Forestry. Each has been clearcut at some point within the last twenty years and their respective "ages" are determined by the number of years since the area was logged. Sites are identified in this report according to their age and an identifying letter (i.e. $20 \mathrm{a}$ and $20 \mathrm{~b}$ represent the two twenty year old sites evaluated). Every effort was made to ensure that each of the project sites had been allowed to revegetate naturally without the influence of chemical treatment, planting, or burning. Maps and descriptions of each site are located in Appendix *.

\subsection{Field data collection}

Prior to the initiation of sampling, it was decided that vegetation should be divided into 


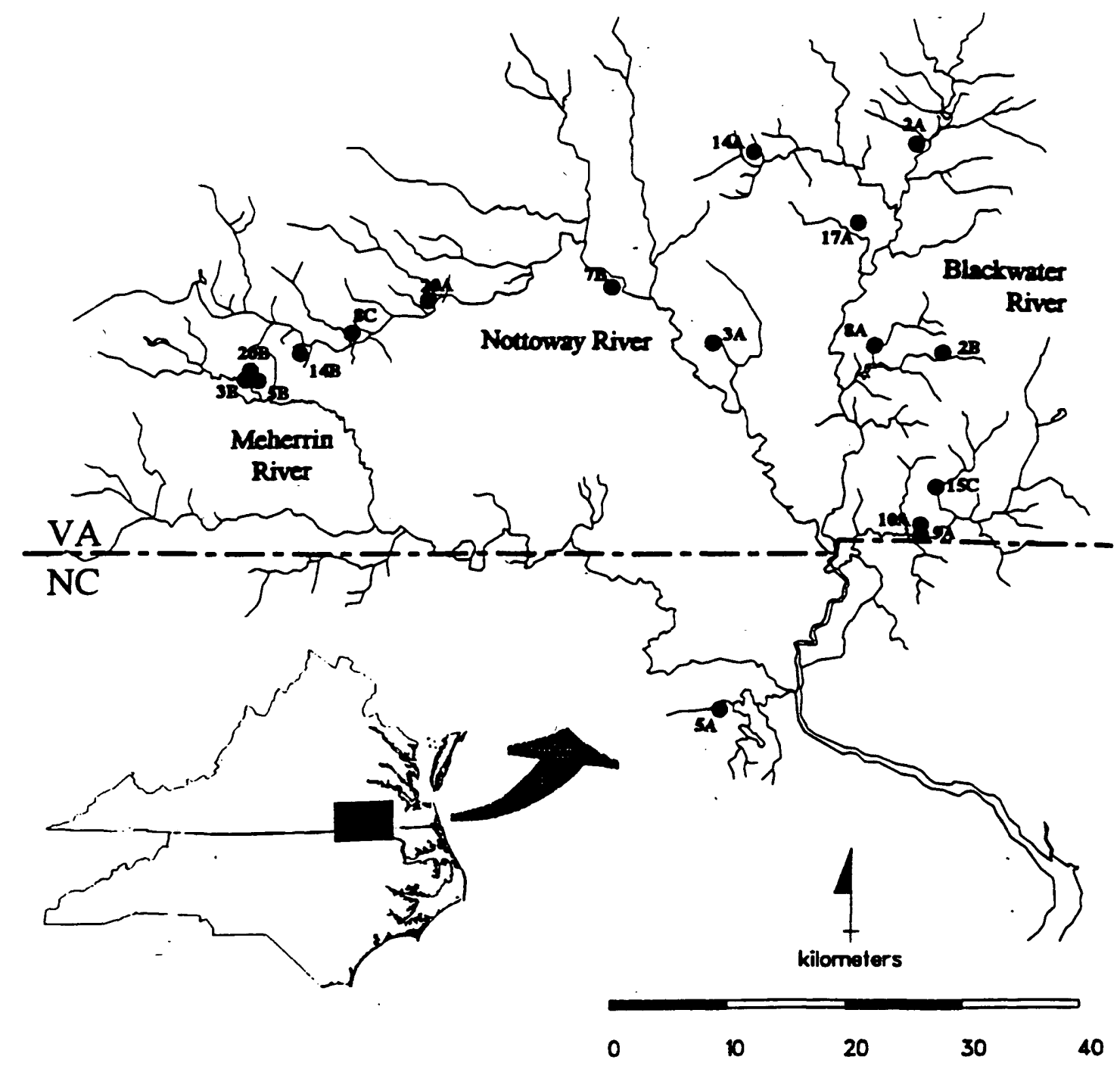

Figure 1. Locations of project sites. 
three sampling components: herbaceous (or ground plane), understory, and overstory. The herbaceous component included all herbaceous species, all vines, and woody plants (trees and shrubs) less than $50 \mathrm{~cm}$ tall. The understory consisted of saplings and shrubs equal to or greater than $50 \mathrm{~cm}$ tall but less than $2.5 \mathrm{~cm}$ dbh (diameter at $1.5 \mathrm{~m}$ above ground). The overstory included all woody vegetation equal to or greater than $2.5 \mathrm{~cm}$ dbh (Mader 1990, Rheinhardt 1992).

Sampling points for understory and overstory components were located using a random walk technique, ensuring that wetlands were sampled evenly yet randomly while avoiding any overlap of plots (Tilman 1988). The number of sampling points per site ranged between four and ten, depending in large part on the density of understory at a particular site.

Because of the relative lack of overstory in early successional forested wetlands and the necessity of avoiding upland/wetland ecotones in some of the more narrow project sites, $2.81 \mathrm{~m}$ radius $\left(25 \mathrm{~m}^{2}\right)$ circular plots were selected as efficient, yet reasonably thorough, means of sampling both understory and overstory vegetation. Despite the benefits of reduced variance, the larger plots more typically found in studies of swamp community structure (Doumlele et al. 1985, Rheinhardt 1992) were considered too cumbersome in the dense understory of many project sites, while the various plotless methods available would have provided little information in younger stands and not adequately accounted for the coppice regrowth on stumps remaining from the clearcut. Within each circular plot, stems were tabulated by species, sampling component, and origin (i.e., seedling or sprout). The dbh of overstory stems was measured to the nearest half centimeter, while understory vegetation was measured at $40 \mathrm{~cm}$ above the base for trees and at 3 cm above the base for shrubs, also to the nearest half centimeter (Mader 1990). Each stem was classified as either a seedling or sprout, being considered sprouts if they originated below $40 \mathrm{~cm}$ on residual stumps and were counted separately if they forked within three centimeters of the 
base (Mader 1990).

The herbaceous component was sampled using quadrats of dimensions $1 \mathrm{~m} \times 0.5 \mathrm{~m}(0.5$ $\mathrm{m}^{2}$ ) that were positioned in a stratified random manner based on the centerpoints of the radial plots. Density for each species was measured by counting only those plants actually rooted within the quadrat. Total herbaceous cover and coverage of each species present within the quadrat, regardless of root location, was determined by a modified Daubenmire (1968) technique, involving ocular estimation of cover and assignment into one of seven coverage classifications: trace, $1-5 \%, 5-25 \%, 25-50 \%, 50-75 \%, 75-95 \%$, or $95-100 \%$ (Rheinhardt 1992 ).

At each study site, two soil samples were taken from each of two locations consistent, where possible, with the one or two elevations most representative of vegetation sampling points. A standard chemical analysis, including measurements of $\mathrm{pH}$, organic matter content, and cation exchange capacity, was performed on each sample by the Department of Crop and Soil Environmental Sciences at Virginia Polytechnic Institute and State University.

Hydrologic characteristics of study sites were evaluated through installation and monitoring of PVC groundwater wells. Wells were constructed of screened 4-inch PVC pipe positioned from approximately $1-2 \mathrm{~m}$ below ground to within $15 \mathrm{~cm}$ of the surface and attached to solid 4-inch PVC pipe that extended about $1 \mathrm{~m}$ above the ground surface. Because of the unavailability of remote dataloggers and the resulting time considerations involved in checking the wells manually, only one well was installed at most sites. At three project sites, two monitoring wells were established to indicate any possible differences in microsite hydroperiod. Water levels were recorded biweekly for one year, although occasional datapoints are missing where high water levels rendered sites inaccessible.

\subsection{Data analysis}


Information obtained during field sampling was used to calculate estimates for population densities and dominance according to the following formulas:

$X_{\text {den }}=X_{\text {tot }} /\left(\left(A_{\text {plot }}\right)\left(N_{\text {plot }}\right)\right)$

where: $X_{\text {den }}=$ absolute density of species $X\left(\right.$ in $\left.\# / \mathrm{m}^{2}\right)$,

$\mathrm{A}_{\text {plot }}=$ area of individual plots $\left(0.5 \mathrm{~m}^{2}\right.$ or $\left.25 \mathrm{~m}^{2}\right)$, and

$\mathrm{N}_{\text {plot }}=$ total number of plots on a given site;

$X_{\text {dom }}=\left(X_{b a}\right)\left(X_{d e n}\right)$

where: $\mathrm{X}_{\mathrm{dom}}=$ absolute dominance of species $\mathrm{X}$, and

$\mathrm{X}_{\mathrm{ba}}=$ mean basal area (cover estimation for herbaceous species) of individuals of species $\quad X\left(\right.$ in $\left.\mathrm{m}^{2}\right)$.

The relative values according to species and sampling component was then determined for each of these measures using the following formulas:

$\mathrm{RX}_{\text {den }}=\mathrm{X}_{\text {den }} /$ Tot $_{\text {den }}$

where: $\mathrm{RX}_{\text {den }}=$ relative density of species $\mathrm{X}$, and

Tot $_{\text {den }}=$ sum of density values for all species;

$\mathrm{RX}_{\text {dom }}=\mathrm{X}_{\text {dom }} /$ Tot $_{\text {dom }}$

where: $\mathrm{RX}_{\mathrm{dom}}=$ relative dominance of species $\mathrm{X}$, and

Tot $_{\text {den }}=$ sum of dominance values for all species; 
Species importance values were then formulated for each sampling component by taking one-half of the sum of relative density and relative dominance (Mueller-Dombois and Ellenberg 1974).

Community dynamics were than analyzed using a variety of ordination techniques available as part of the CANOCO software package developed by Ter Braak (1988). Results of the canonical correspondence analysis are presented here using species-site biplots that detail the first two ordination axes. The role of measured environmental variables, such hydrology and soil chemistry, was evaluated by examining their correlation with each other and with the first two ordination axes. The changes in community characteristics associated with age were minimized by using that factor as a covariable. 


\section{Results}

The results for each site, without respect to the particular species present, are contained in Table 1. Densities and basal areas have been standardized to hectares to facilitate comparison with other studies. Overstory densities range from 0 stems/hectare at Site 3a to 5920 stems/hectare at 14a. Site 3a, which was whole-tree chipped at harvest leaving few visible stumps, also had the lowest proportion of stems originating as coppice in both the overstory and understory. Site $14 \mathrm{a}$, on the other hand, exhibited the prevalence of coppice sprouts that was characteristic of a number of project sites and that generally corresponded with enhanced stem densities. Likewise, Site 15a, which had the second highest percentage of overstory stems originating as coppice, was the most productive site in terms of total basal area, more so than even the seventeen and twenty year old sites. In comparing the overstories of sites of the same age, a notable discrepancy exists between the two 20-year-old sites. Despite having roughly similar densities, Site $20 \mathrm{~b}$ exhibited almost twice the basal area as Site 20a. Not accounted for in the data, though, was a considerable mortality among the canopy trees at Site 20a, limited almost entirely to Salix nigra and, to a lesser extent, Populus heterophylla. Understory densities displayed considerable variability throughout the seventeen project sites, ranging from just over $1500 \mathrm{stems} /$ hectare to greater than $30,000 \mathrm{stems} /$ hectare. Some notable aberrations would appear

to be Sites $8 \mathrm{a}, 8 \mathrm{~b}$, and $17 \mathrm{a}$. At the latter two, beaver activity resulted in numerous stumps that produced a prodigious number of new sprouts, while at site $8 \mathrm{a}$, suckering at the base of $S$. nigra saplings substantially augmented understory stem densities. This explains the notably higher understory basal área at Site 8a, since it was not subjected to the post-establishment reduction in basal area associated with beaver activity. 


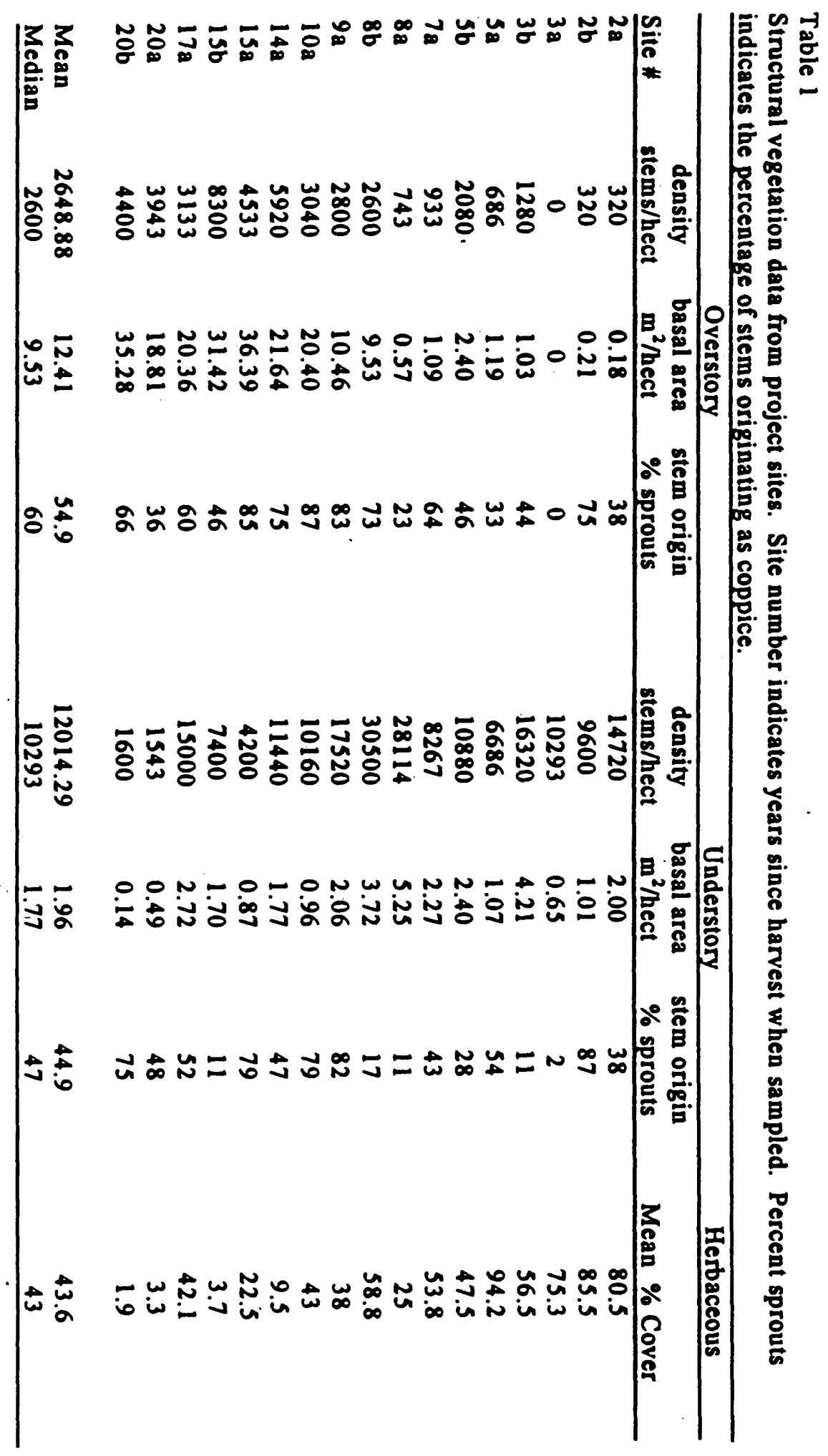


Tables 2 and 3 list importance values of the dominant and co-dominant species within the overstory and understory components, respectively, for all of the project sites combined. Although a total of twenty-seven species were sampled in the overstories of project sites, only nine were dominant or co-dominant on at least one project site. Dominance and co-dominance were determined by the species or group of species, respectively, as ranked by importance values, necessary to accumulate a combined importance value greater than 50 within a particular site. It should be noted that, because of difficulty in identifying the particular species of such young specimens from the genus Fraxinus, all occurrences were classified as Fraxinus spp. Several species and subspecies are, in fact, known to occur within this geographical region, including $F$. caroliniana, F. profunda, and, primarily, F. pennsylvanica (Rheinhardt 1992, Glascock and Ware 1979). As indicated by the total importance value for all sites combined, $A$. rubrum and $S$. nigra were the dominant species throughout the study. However, the fact that $S$. nigra was the only species occurring in the overstory of site $2 b$ enhances its relative importance with respect to this measure. Three species - Platanus occidentalis, Ulmus americanus, and one unidentified species referred to as "T2b10" - occurred in the overstories of no more than two project sites. In the case of $P$. occidentalis and $T 2 b 10$, they were generally found to occur on the edges of or on hummocks within the sampled wetlands, while limited $U$. americanus populations possibly reflect the lingering impact of Dutch Elm, which tends to reduce seed production in mature trees (G. Silberhorn, pers. comm., S. Ware, pers.comm.).

When understory importance values are summed for all stands, $A$. rubrum and $S$. nigra are joined by Fraxinus spp. and $T$. distichum as the dominant species among all seventeen project sites, as indicated by total importance values greater than 200 . The presence of $S$. nigra, dominant in the understories of several project sites, greatly diminishes between the seventh and tenth growing seasons, correlating with the early stages of canopy development. Between years 


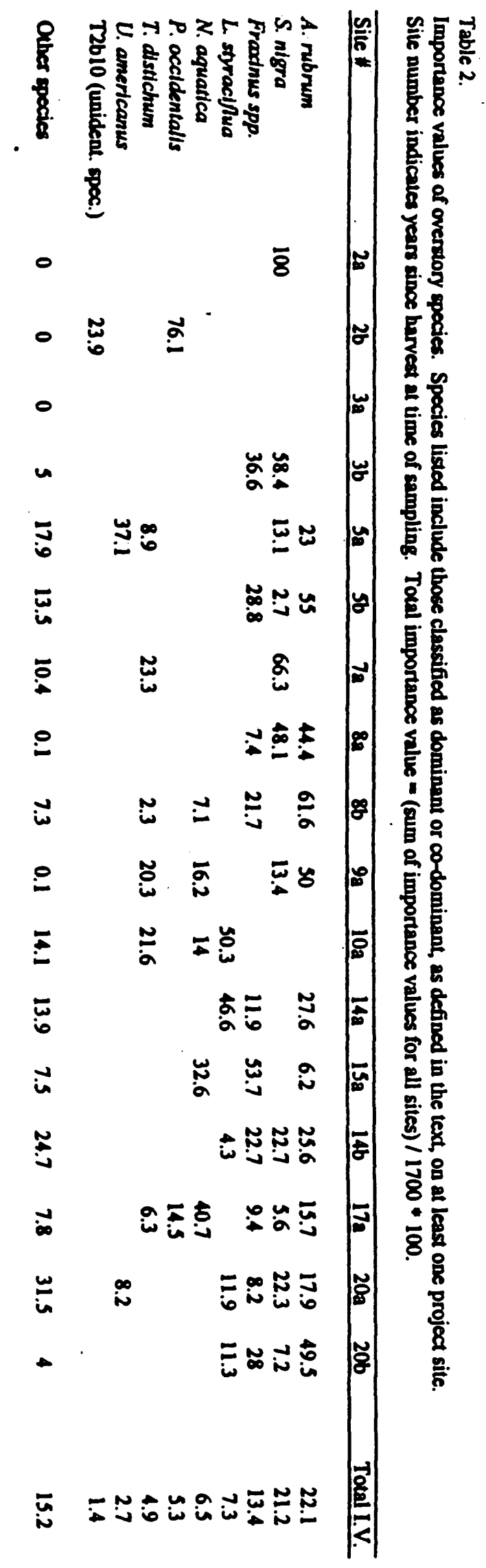




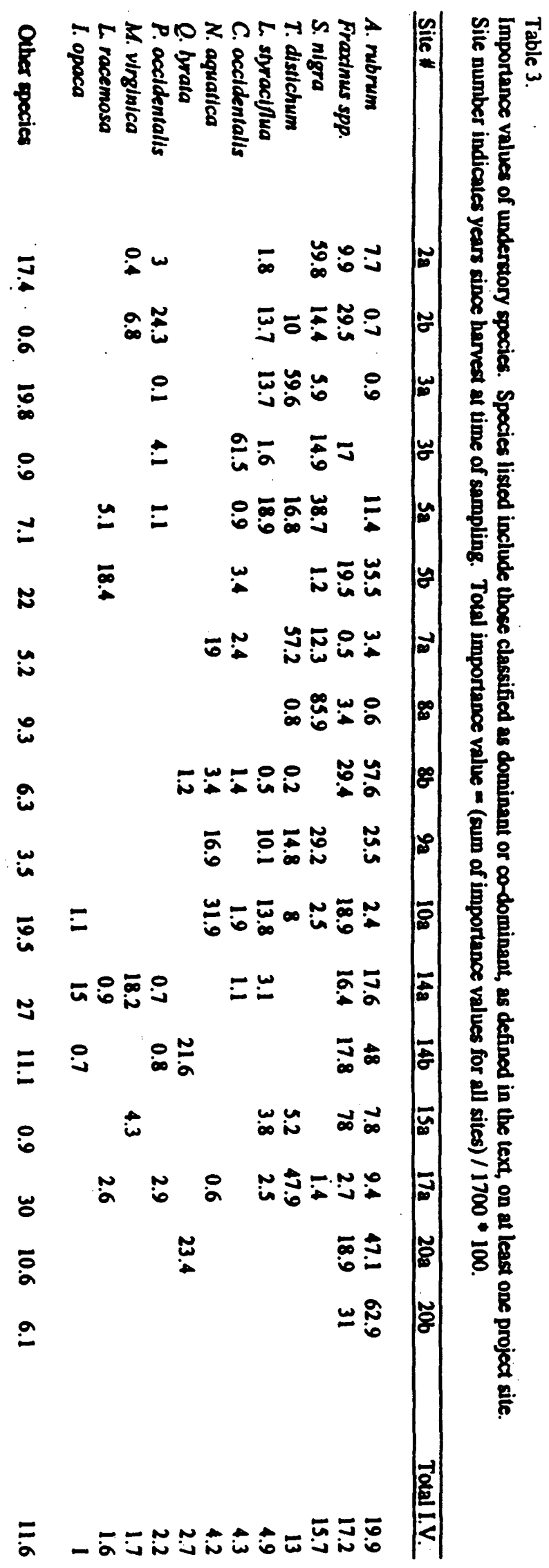


ten and twenty, the increasing presence of an understory of shade-tolerant sub-canopy and canopy species is indicated by the presence of Ilex opaca and Quercus lyrata, respectively.

Data obtained from monitoring groundwater wells is shown in Table 4. Fluctuation, indicated by the range of measured water levels at a given site, was greatest at the two 20 year old sites, where measured highs and lows were over a meter apart. Flooding regimes at these two sites were somewhat different, though, with site 20a exhibiting flooding at the surface for approximately $68 \%$ of the year compared to $28 \%$ of the year for site $20 \mathrm{~b}$. At the other end of the hydrologic spectrum, sites $8 \mathrm{a}$ and $2 \mathrm{a}$ had water levels ranging less than 20 centimeters. Again, this was not necessarily indicative of an overwhelming similarity between the hydrologic regimes of the two sites. Water levels never dropped below $30 \mathrm{~cm}$ at site $8 \mathrm{a}$, while at site $2 \mathrm{a}$ surface flooding was never observed (although there were secondary indicators of its presence). At two sites, 7a and 8a, measurements do not accurately reflect the high end of water level ranges with respect to the other sites because on several occasions the logging roads by which they were accessed were impassable due to high water levels.

Table 5 represents soil data for the entire suite of measured variables. In general, there were few apparent trends associated with site age. Soil $\mathrm{pH}$ levels ranged from 4.2 to 5.7 and organic carbon content ranged from 0.34 percent to 8.36 percent at a depth of $10 \mathrm{~cm}$. Although there did appear to be a general decrease in soil $\mathrm{pH}$ over time at a depth of $10 \mathrm{~cm}$, the lack of multiple samples from project sites. and the considerable within-site variability, particularly at sites with a high degree of microtopographic variability, precluded analysis of the significance of apparent trends in soil data. Site $2 a$ was notable in that it exhibited among the highest values for each of the variables indicated in Table 5 .

The initial CCA of the 17 sampled stands (Figure 2) revealed a fairly even distribution of stands along the vertical ( $y$, second) axis. However, site $2 b$ was so vegetatively different from 


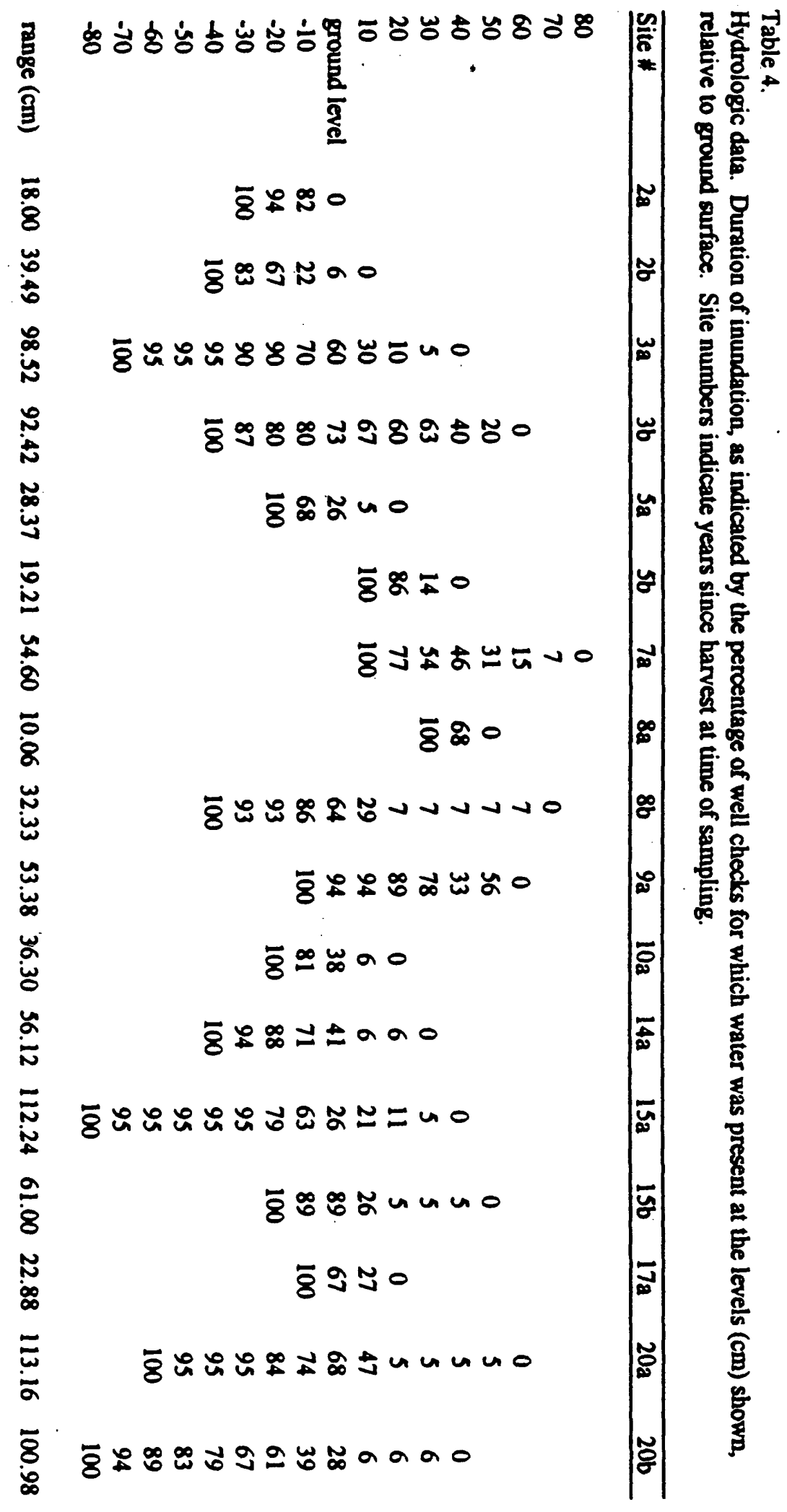


Table 5.

Soil chemistry at depth of approximately $10 \mathrm{~cm}$.

\begin{tabular}{lcccccc}
\hline Site \# & pH & $\begin{array}{c}\text { Org C } \\
\%\end{array}$ & $\begin{array}{c}\mathrm{Ca} \\
(\mathrm{meq} / 100 \mathrm{~g})\end{array}$ & $\begin{array}{c}\mathrm{Mg} \\
(\mathrm{mog} / 100 \mathrm{~g})\end{array}$ & $\begin{array}{c}\mathrm{K} \\
(\mathrm{mog} / 100 \mathrm{~g})\end{array}$ & $\begin{array}{c}\mathrm{CEC} \\
(\mathrm{meg} / 100 \mathrm{~g})\end{array}$ \\
\hline $2 \mathrm{a}$ & 5.7 & 8.36 & 15.1 & 2.3 & 0.54 & 33.74 \\
$2 \mathrm{~b}$ & 5.5 & 3.07 & 8.28 & 0.64 & 0.12 & 21.04 \\
$3 \mathrm{a}$ & 4.5 & 2.72 & 1.62 & 0.43 & 0.14 & 16.79 \\
$3 \mathrm{~b}$ & 4.7 & 3.39 & 4.45 & 1.31 & 0.45 & 23.81 \\
$5 \mathrm{a}$ & 5.3 & 4.15 & 8.02 & 2.18 & 0.55 & 28.55 \\
$5 \mathrm{~b}$ & 4.7 & 2.59 & 4.24 & 2.19 & 0 & 23.63 \\
$7 \mathrm{a}$ & 4.5 & 1.33 & 5.53 & 2.49 & 0.14 & 21.16 \\
$8 \mathrm{a}$ & 4.4 & 3.03 & 1.37 & 0.43 & 0.1 & 18.70 \\
$8 \mathrm{~b}$ & 5.1 & 0.37 & 5.73 & 0.94 & 0.09 & 12.76 \\
$9 \mathrm{a}$ & 4.7 & 1.41 & 2.85 & 0.52 & 0.09 & 13.46 \\
$10 \mathrm{a}$ & 4.7 & 4.6 & 3.53 & 0.93 & 0.24 & 29.70 \\
$14 \mathrm{a}$ & 4.2 & 1.07 & 0.1 & 0.1 & 0.1 & 19.70 \\
$15 \mathrm{a}$ & 4.8 & 3.17 & 3.12 & 0.74 & 0.22 & 16.33 \\
$15 \mathrm{~b}$ & 4.6 & 1.71 & 4.26 & 1.57 & 0.1 & 22.08 \\
$17 \mathrm{a}$ & 4.7 & 0.34 & 0.22 & 0.08 & 0.04 & 15.74 \\
$20 \mathrm{a}$ & 4.4 & 3.02 & 5.82 & 0.88 & 0.14 & 23.24 \\
$20 \mathrm{~b}$ & 4.5 & 2.29 & 3.29 & 1.07 & 0.18 & 19.14 \\
\hline
\end{tabular}


the other sixteen sites that, along the horizontal ( $x$, second) axis, it proved to be obviously disjunct from the other sites, which themselves exhibited little variation along that particular axis. The most obvious reason for this difference is the dominance of $P$. occidentalis in the overstory and its co-dominance in the understory, with I.V.'s of 76 and 24 , respectively. With regard to morphology of the site, $2 b$ is more adequately characterized as a braided stream complex, separated by the hummocks on which $P$. occidentalis is regenerating predominantly as coppice. Also, the site was the only one at which no surface flooding was recorded during well checks, being observed only once during the entire monitoring period in the course of other research on the site. Instead, water was generally confined to the well-defined channels, a trait not shared by any of the other project sites. Of note also in this ordination was the inverse relationship between the presence of organic carbon in the soil and the percentage of overstory stems originating as coppice.

Because of these differences, site $2 b$ was removed from subsequent ordinations. With the disjunct stand removed, a considerably more distinct grouping of the sites was revealed (Figure 3). By delineating the understory importance values of $T$. distichum and $S$. nigra as indicated in the biplot, the presence of three types of sites is indicated - Cypress, Willow, and Mixed Hardwood. The environmental parameter most highly correlated with the first ordination axis is the percentage of overstory stems originating as coppice, which clearly separates the Mixed Hardwood sites from the Cypress and Willow sites. Potassium is most highly correlated with the second axis, although the significance of this is not readily apparent.

In the final ordination (Figure 4), age was inserted as a covariable, effectively minimizing its influence on the outcome. Three of the Willow sites now fell into the larger cluster with the Mixed Hardwood stands, indicating that, as these sites age, they are most likely succeeding into communities more representative of those regenerating as coppice after the 


\section{Canonical Correspondence Analysis}

\section{All Sites, No Covariables}

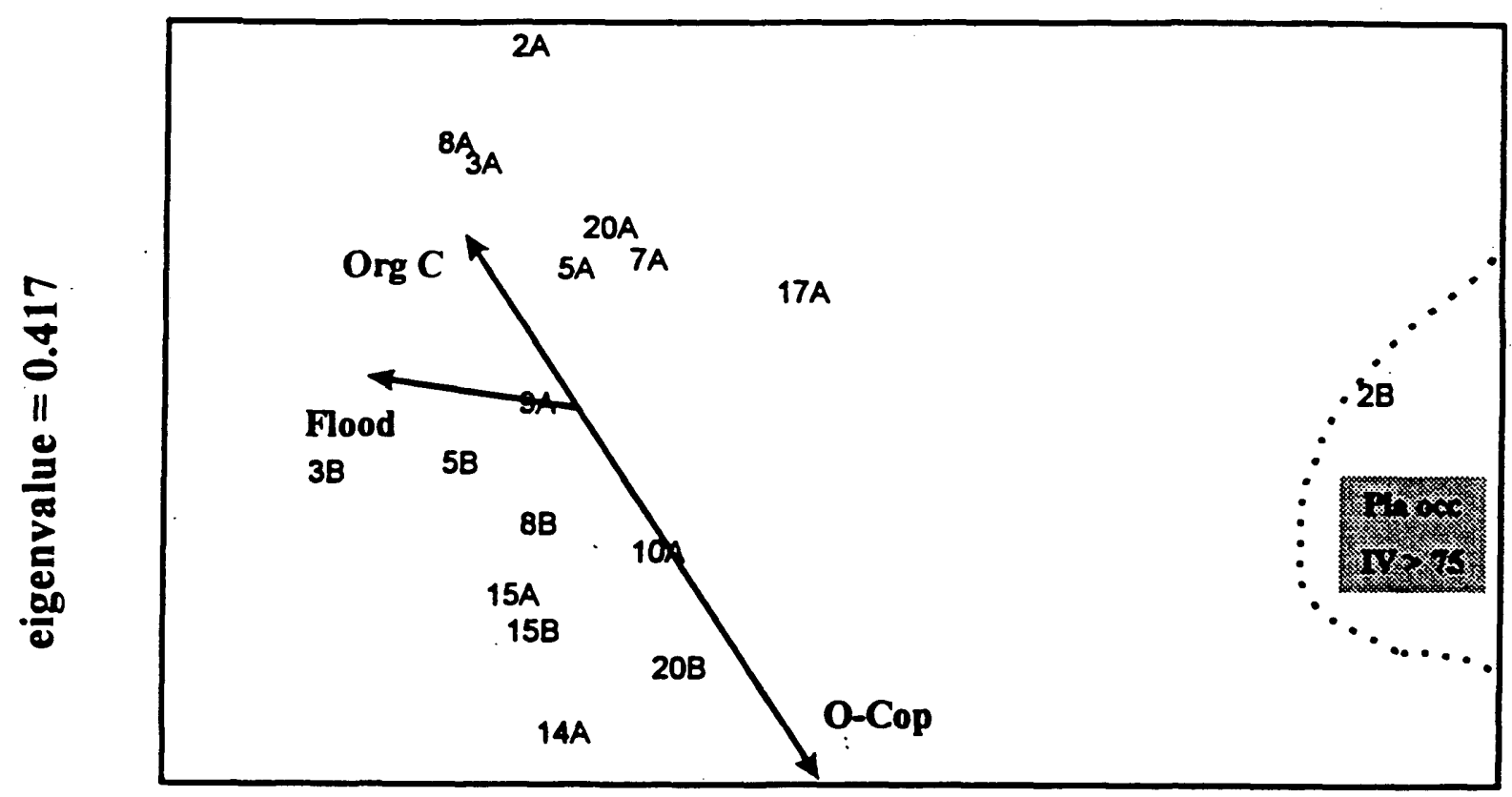

eigenvalue $=\mathbf{0 . 5 0 3}$

Figure 2. Canonical correspondence analysis of all project sites with no covariables. Vegetation data includes understory and overstory importance values for each species recorded in those strata (i.e. two values may exist for each species). Environmental variables included information related to hydrologic regime, soil chemistry, and stem origin. Only those environmental variables exhibiting the highest correlation with ordination results are depicted by arrows in the figure. Org $C=$ organic carbon; Flood = duration of flooding as a percentage of the calendar year; $\mathrm{O}$ Cop = percentage of overstory stems originating as coppice. The dashed line encloses the only site in which Platanus occidentalis exhibited an overstory importance value greater than 75 . 


\section{Canonical Correspondence Analysis}

\section{Site 2b Removed}

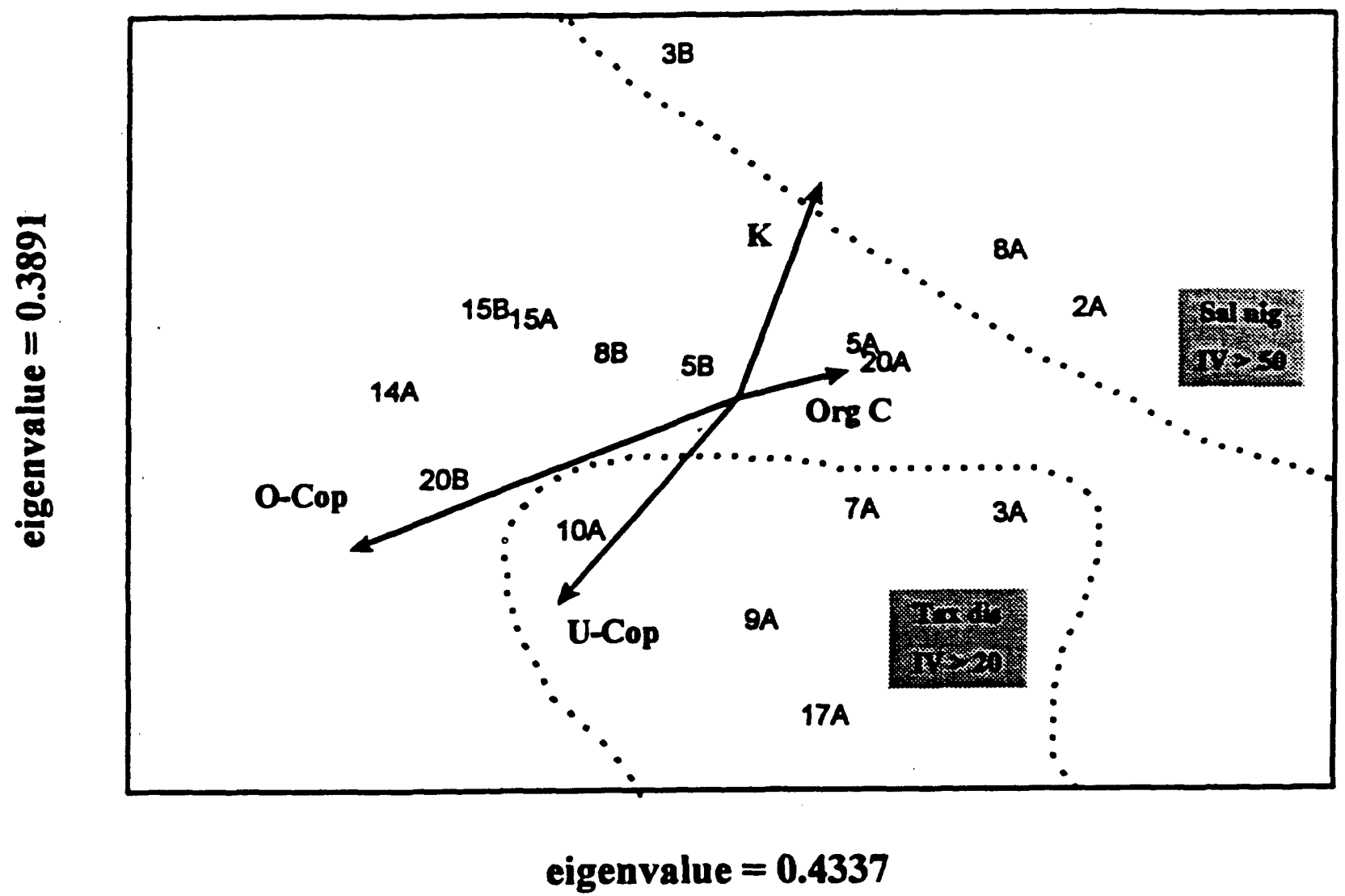

Figure 3. Canonical correspondence analysis with Site $2 \mathrm{~b}$ removed and no covariables; other covariables identical to Figure 2 . U-Cop = percentage of understory stems originating as coppice. The upper dashed line encloses those sites in which Salix nigra exhibited an overstory importance value greater than 50 . The lower dashed line encloses those sites in which Taxodium distichum exhibits an understory importance value greater than 30 . 


\section{Canonical CorrespondenceAnalysis}

\section{Site 2b Removed, Age Covariable}

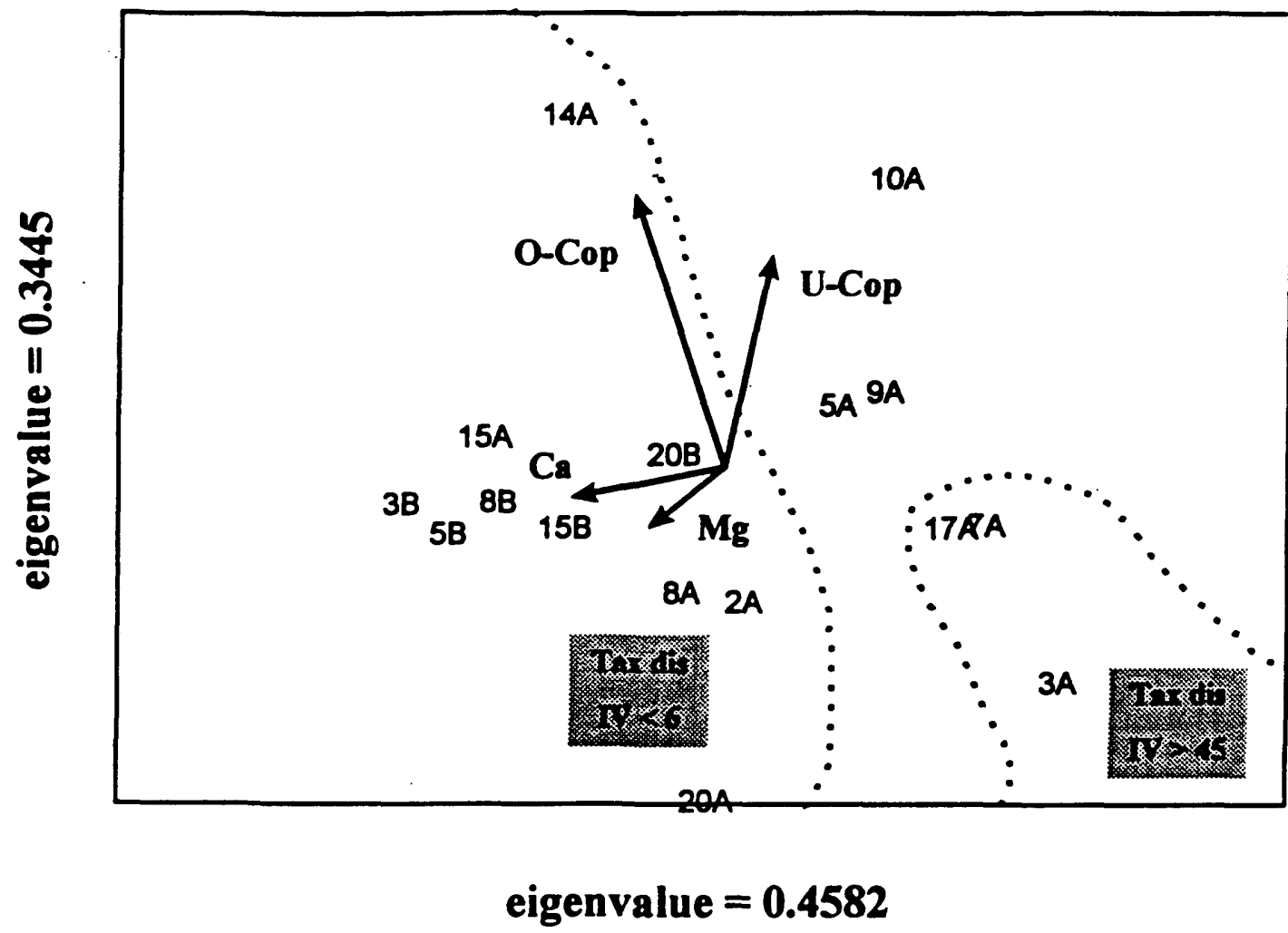

Figure 4. Canonical correspondence analysis with Site $2 b$ removed from the ordination and age inserted as a covariable. The dashed line to the right encloses those sites in which Taxodium distichum exhibits an understory importance value greater than 45 . The dashed line to the left encloses those sites in which Taxodium distichum exhibits an understory importance value less than 6 . 
clearcut. The three sites most dominated by $T$. distichum still fell out distinctly as Cypress stands; however, three other sites - 5a, 9a, and 10a - fell out between the Mixed Hardwood stands and the Cypress stands on the first axis. On the second axis, these sites were distinguished from the Cypress stands by the generally higher prevalence of coppice. As observed in the field, these sites tended to have a substantial degree of microtopographic variability. Thus, they exhibited a wider range of environmental conditions, resulting in species compositions similar to Mixed Hardwood stands in some areas and Cypress stands in others. Calcium was the variable exhibiting the greatest correlation with the horizontal axis, a result also noted by a decrease in average values for the clusters moving from left to right on the biplot. 


\section{Discussion}

\subsection{Species composition of project sites}

Excluding Site 2a, where the significant areal extent of drier hummocks may have resulted in a plant community composition considerably different than that of the other 16 sites, the ordination results indicated the presence of two general community types. The first, referred to as Cypress, is characterized by an understory of $T$. distichum and is represented primarily by three sites and by portions of three others. The differences between the three principal sites, however, give an indication of confounding interaction of factors that lead to development of this community type. For example, the three-year-old Cypress site exhibited a $1 \mathrm{~m}$ range of water levels comparable to that of several 15-20 year old sites, while the seventeen-year-old Cypress site only fluctuated over approximately $25 \mathrm{~cm}$ throughout the course of the study. Furthermore, while the seven-year-old Cypress site was continuously flooded at the surface, the three-year-old and seventeen-year-old Cypress sites were flooded at the surface only 60 and 66 percent of the time, respectively. Human impacts may account for some of the different environmental characteristics of these three sites: At the seventeen-year-old Cypress site, a cypress tupelo swamp upstream has been artificially impounded, which may have implications for the hydrologic conditions of the site during portions of the year. The characteristic common to all three of the Cypress stands is a low percentage of stems originating as coppice, in spite of the fact that $T$. distichum displayed the capability to sprout from stumps on these and other sites. The "whole tree chipping" of one Cypress site likely left few viable stumps on which coppicing could take place and the dense seedlings on the site did not appear to be originating as root sprouts. At another, the stumps remaining from the clearcut are massive in comparison to those seen 
producing viable sprouts elsewhere, supporting the assertion that increased stump size, interms of both diameter and height, serves to minimize the likelihood of viable sprout production (B. Heeren, pers. comm.). From the perspective of landscape geomorphology, Sites 3a and 17a can both be considered small stream bottoms, while Site 7a is a major floodplain of the Nottoway River and, as such, is hydrologically impacted more by overbank flooding than by the groundwater levels predominantly influencing the other two sites. In retrospect, it is believed that a logging road may in fact be augmenting the effect of overbank flows by impounding flood waters and substantially increasing the duration and depth of flooding on the site. Given the lack of continuous or even prolonged flooding, it is unclear why the three-year-old Cypress site still exhibits such pronounced dominance by $T$. distichum, except that it is surrounded by an expansive complex of early successional pine uplands and agricultural fields, with no mature wetland species, save a few remnant mature specimens of $T$. distichum, in close enough proximity to provide an effective seed source (Clewall and Lea 1990). In fact the only portion of the swamp being colonized is a narrow strip on either side of a short road crossing. (Considering that $S$. nigra utilizes wind as its primary seed dispersal mechanism and that the species appeared to excel under a wide variety of hydrologic conditions at various project sites, it is unclear why its presence at this particular site would be limited to the road crossing.) Therefore, because of anthropogenic modification of adjacent areas, the developing Cypress community at the threeyear-old site is perceived to be acting as an artifact of past site conditions, irrespective of current environmental characteristics that would seem to render the site more suitable for the establishment of other wetland species.

As indicated in Figure 3, those sites not classified as Cypress can be subdivided into two separate groups - the Mixed Hardwood sites and the Willow sites. During early stages of succession, a significant portion of early regeneration can be attributed to coppice sprouts, which 
were also noted recently by Messina et al. (1997) as accounting for 83 percent of stems one year following clearcutting of a Texas floodplain forest. The overwhelming prevalence of this type of regeneration potentially limits the capacity of the system to respond to small-scale environmental changes that would normally produce incremental changes in species composition over time. The Mixed Hardwood Sites also tend to exhibit greater fluctuations in water levels, which is believed to reflect the ability of established root networks enhance evapotranspiration rates relative to sites regenerating predominantly from seed. As sites of this classification increase in age, so do the measured fluctuations in water levels. The exception to this is Site $5 b$, which is similar to the seven-year-old Cypress site in that it is located in the floodplain of a major coastal plain river rather than a small stream bottom.

The Willow sites, as represented by Sites $2 \mathrm{a}$ and $8 \mathrm{a}$, are characterized by a dominant overstory of $S$. nigra and water level fluctuations of less than $20 \mathrm{~cm}$. Although multiple stems are exhibited by $S$. nigra specimens at both sites, actual coppicing is rare, a condition not unexpected given the fact that the species was not a likely constituent of the canopy prior to clearcutting. The third Willow site identified by the ordinations is important in that it offers an insight into the time frame over which this community is succeeding into a more typical Mixed Hardwood stand. Salix nigra, overwhelmingly dominant during the first ten to fifteen years of regeneration as indicated by remaining live specimens and substantial amounts of both standing and fallen deadwood, has within twenty years begun to reach the end of its life span and is not reproducing, either vegetatively or by seed, under the limiting conditions of a closed canopy. Also of importance is the presence of ecologically desirable mast-producing species in the understory of twenty-year-old Willow site. It is thought that the success of this component, so often sought after in creation and restoration efforts and generally uncommon in the secondary growth characterizing many of the bottomland hardwood forests remaining in southeastern 
Virginia, is directly related to the stabilization of site hydrology and the sporadic canopy openings associated with the mortality of $S$. nigra. Under these conditions, species best adapted to specific microsites are more likely to succeed because they are insulated from to the dramatic changes in site conditions during the years immediately following timber harvest.

A review of the available literature indicates a high degree of correlation between the Cypress sites in this study and those identified by past researcher in the region. Plunkett and Hall (1995) identified $T$. distichum and $N$. aquatica as the important dominants in flooded open swamps, partially flooded swamps, and stream bottoms. No quantitative analysis of hydrology is offered, however, except to mention that the flooded open swamps remain deeply flooded throughout the year and the partially flooded swamps and stream bottoms exhibit prolonged, but not continuous, flooding. One notable difference between these results and those of Plunkett and Hall (1995) is the role of $N$. aquatica in partially flooded swamps and stream bottoms. While it was identified as an important species at several of the current project sites, its presence was more attributable to coppicing than to seedling establishment. The increased dominance in the mature canopies of Plunkett and Hall (1995) is likely due to past selective cutting of $T$. distichum throughout the Southeast, which has often been cited as leading to domination by $N$. aquatica of wetlands historically characterized as Cypress swamps (Wharton et al. 1982). As recent research has indicated (Stubbs 1973, McKnight and Johnson 1975, Conner 1994, Pavel 1993), clearcutting of cypress stands will result in a more effective recovery of natural species distributions, which is consistent with the dominance of $T$. distichum on the understories of Cypress sites in this study.

Glascock and Ware (1979) noted that, aside from a few geographically limited species, there was a remarkable similarity in the composition and structure of stream bottoms from New Jersey all the way down to Florida. This study generally corresponds with their findings 
regarding the dominant species associations. The most notable difference would be the reduced significance of Carpinus caroliniana among sites in the current study, whereas Glascock and Ware (1979) and Plunkett and Hall (1995) consistently found it to be a prevalent constituent of the overstories of bottomland hardwood forests in southeastern Virginia. Characterized as a small understory tree by Godfrey and Wooten (1981), its presence in the overstories of mature sites is, again, probably the result of past selective harvests throughout the region, which allowed economically undesirable understory species like $C$. caroliniana to take advantage of the increased resource availability and become important components of the overstory. Given the lack of old growth bottomland hardwood forests in the region, one can only speculate as to the role of the species under natural circumstances; however, it is apparent that the species is quickly outcompeted during the earlier stages of post-clearcut regeneration.

\subsection{Quantitative aspects of project data}

Generally speaking, the limited amount of past research on the early successional development of bottomland hardwood forests and the inconsistent data collection protocols make comparison with the quantitative data of other studies problematic. However, the results of these other studies can provide a context by which to gauge the successional rates of projects examined as part of this study. Within the same region, Doumlele et al. (1985) recorded a total basal area of $91.35 \mathrm{~m}^{2} /$ hectare and overstory densities of nearly $2750 \mathrm{stems} / \mathrm{hectare}$ in a mature tidal freshwater swamp. This was substantially more productive than the four Savannah River floodplain forests examined by Jones et al. (1994), where overstory basal areas ranged between 29 and $38 \mathrm{~m}^{2} /$ hectare, and the seventeen sites examined by Megonigal et al. (1997), where basal areas ranged from 13.6 to $54.5 \mathrm{~m}^{2} /$ hectare and densities of live stems ranged from 330 to 930 
stems/hectare. Given natural variation of this magnitude and the lack of pre-clearcut quantitative data on project sites, the difficulty of estimating the rate at which they are proceeding towards a mature canopy becomes evident. In a similar study, Bowling and Kellison (1983) noted bottomland hardwood overstories developing at rates remarkably similar to those noted for Mixed Hardwood stands in this study. In fact, the slight differences that did occur can likely be accounted for by the fact that overstory stems in the former study were limited to those over 10 cm. Like the present study, much of the regeneration was attributed to coppice sprouts; however, data from the Cypress and Willow stands, where coppice sprouts were few and regeneration much slower, suggest that physical and/or biological characteristics may be influencing the successional trajectory of project sites.

One of these characteristics that has not been previously addressed is the presence of wetland soils. Given the consistent presence of established wetland soils at project sites, it is difficult to estimate their relationship to early successional trajectory following clearcut. However, a chronosequence of early successional old field sites in the coastal plain of New Jersey indicates no tree layer whatsoever until 25 years after abandonment (Hanks 1971), and Noon (1996) noted the presence of no trees in the first eleven years following wetland creation on the mineral soils of reclaimed mine lands.

\subsection{Successional processes}

Noon (1996) developed a model of wetland primary succession on reclaimed mine sites using a chronosequence similar to this study. As in van der Valk's $(1981,1982)$ Gleasonian model of succession, two distinct phases in early wetland succession were identified - the Arrival and Establishment Phase, followed after 3 years by the Autogenic Dominance Phase. The 
development of species composition during the Arrival and Establishment is the result of a combination of factors, particularly the availability of resources and species' life history traits. Then, during the Autogenic Dominance Phase, established species compete for dominance through biomass production.

Although used to describe primary succession by Noon (1996), this concept would seem to have applications useful in describing secondary succession of forested wetlands as well. It would seem that the naturally regenerating sites represent an accelerated version of Noon's model of succession, with the rate of acceleration being determined by such factors as coppice sprouting, hydrology, and soil characteristics. This acceleration is in fact accomplishing a goal inherent in many creation and restoration projects of quickly replacing the functions performed by lost wetlands. Specifically, the results of this study are consistent with the presence of an Arrival and Establishment Phase, albeit one that is by no means linked inextricably to the time frame of roughly 3 years described by Noon (1996). The presence of wetland soils alleviates much of the competition for resources evident during primary succession and allows near total cover often by the end of the first growing season. At this point, the site has already begun entering the Autogenic Dominance Phase, the dynamics of which are determined by the species ability to produce biomass, as well as the stress related to the physical regime of the location.

Both of the above factors seem to contribute to dominance by one or several species as the site moves farther into this second successional phase. In the Mixed Hardwood stands, the proliferation of coppice sprouts and subsequent development of a canopy once again creates a resource limitation, except the availability of light is the limiting factor rather than soil nutrients or water. In those sites characterized by the harsh physical regime associated with continuous flooding or high sedimentation rates, an overwhelming dominance is displayed by the few species capable of surviving in those conditions. This idea is consistent with Odum's (1969) assertion of 
an inverse relationship between environmental stress and diversity and was also evident in the results of Johnson et al. (1985), who attributed the success of $S$. nigra on early successional islands in the Atchafalaya River Delta, LA, to the species ability to withstand high sedimentation rates and quickly develop large fibrous root systems. Specific examples in this study were Sites 8a, 7a, and $3 \mathrm{~b}$. Site 8a, which is densely populated by $S$. nigra except for a few higher points where Acer rubrum has sprouted, is bordered by steeply sloping, early successional pine uplands, providing the high energy, high sedimentation environment that largely prevents successful seedling establishment by competing wetland species. In a similar manner, Celtis occidentalis and Polygonum spp. were able to outcompete other species over a significant portion of Site $3 \mathrm{~b}$, located in the first bottom of the alluvial Meherrin River and, thus, subject to a physical environment largely reflective of climatic events across the much larger piedmont watershed. Finally, at Site 7a, where the intense flooding of the adjacent Meherrin River is possibly exacerbated by logging road-induced impoundment, much of the site is covered by dense, monospecific stands of herbaceous perennials. However, towards the edges of the site, where drawdowns are more prevalent and flooding less intense, a more diverse assemblage of both woody and herbaceous species is found.

Two events appear capable of interrupting this cycle of dominance during the Autogenic Dominance Phase. First, as dominant species begin to reach the end of their life span, species growing beneath them are given access to previously limiting resources. This is believed to have occurred at Site 20a, where a significant dieback of $S$. nigra and $P$. heterophyllus is underway and the overstory is in transition from one composed almost entirely of early colonizers to that of a more traditional mixed hardwood stand. The second means of breaking this cycle of dominance is a dramatic alteration in the physical regime of the site, such as the prolonged drawdown of water levels necessary for the germination of $T$. distichum. It is hypothesized that 
the lack of a drawdown has effectively stalled the regeneration of Site 7a and allowed domination of the site by a few species of herbaceous perennials. Both of these situations appear consistent with the "inhibition" model of succession introduced by Connell and Slayter (1977), which states that initial colonists will inhibit the establishment of later colonists until such time as the former are damaged or die.

These processes are represented conceptually in Figure 5. Following clearing of the site, vegetation development is driven largely by hydrologic regime, which is modified on a sitespecific basis soil characteristics and landscape factors, such as positioning of the site in the broader geomorphologic setting and microtopographic variation within a site. The herbaceous community then proceeds towards one of two communities - Mixed Hardwood or Cypress. Development of the Cypress community is mediated largely by the hydrology regime, especially interannual changes related to climatic factors, although factors not specifically examined as part of this study, such as viability of the seed bank, are likely to play a role as well. Development of the Mixed Hardwood community is more directly related to the extent of coppice regeneration on the site, which is driven by such factors as hydrology, harvest regime, and species composition prior to timber harvest. A time scale is deliberately excluded from this model, as this is perhaps the most difficult factor to scale when predicting early successional changes in community structure, point in case being the length of time that a site is "dominated" by herbaceous cover, which in this study ranged from less than two to at least seven years.

\subsection{Relevance of clearcut swamps to monitoring created and restored wetlands}

Given the overriding economic considerations and the often conflicting objectives of development and environmental interests, the establishment of success criteria for compensation 


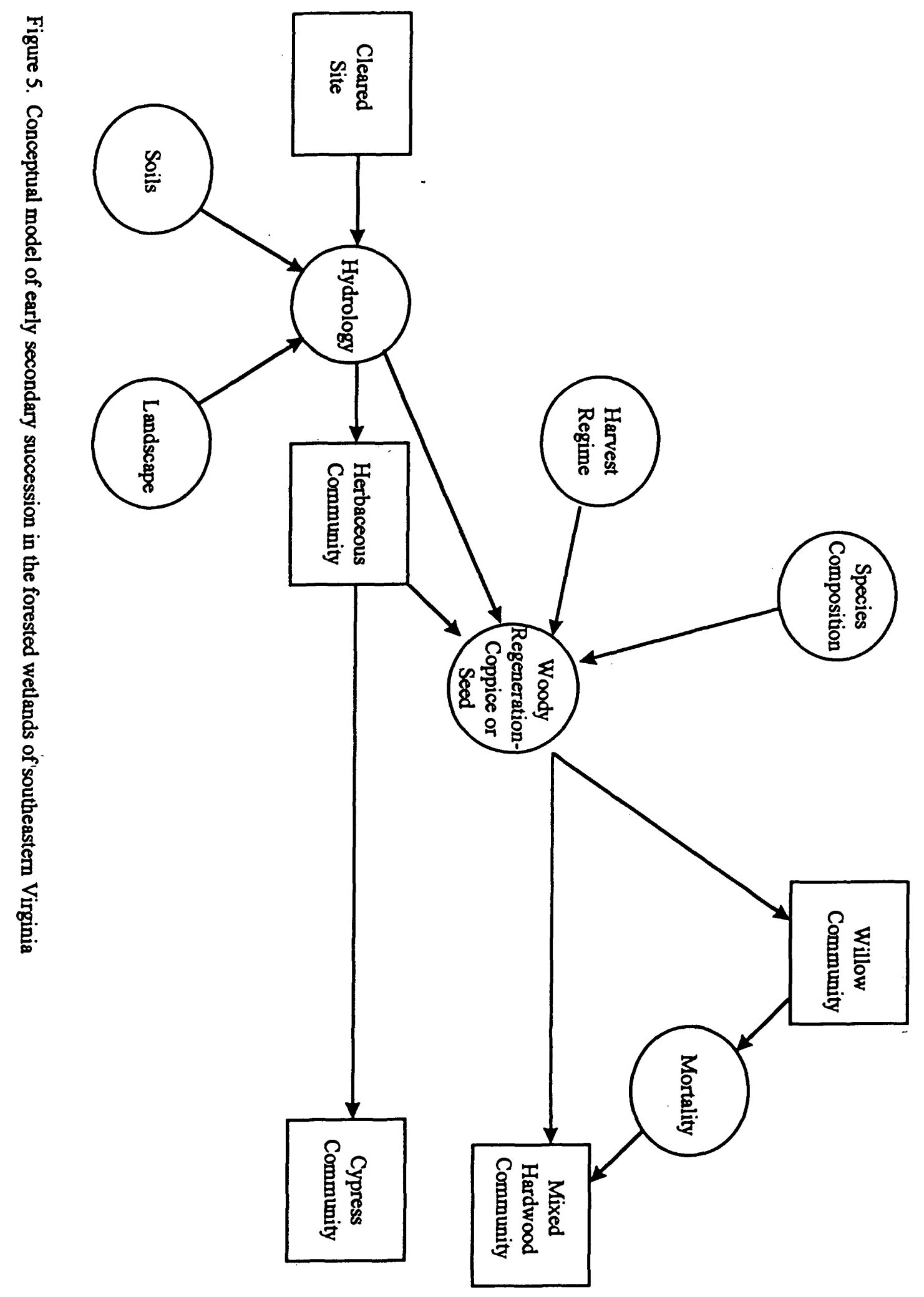


wetlands is and will surely remain a contentious issue. In fact, it is clear from this research that the complex interaction of factors influencing successional trajectories - including the extent of vegetative reproduction, hydrologic regime, seed source, and soil characteristics, to name a few result in a natural variability that makes efforts to develop vegetative success criteria, and still maintain the short time frames now typical of most monitoring programs, prohibitively speculative and not scientifically justifiable.

Despite the variability of this data set, it has nevertheless illustrated successional processes that are germane to any attempt to create or restore forested wetlands in the region. Principally, the role of the Willow community, as a precursor to the subsequent development of a Mixed Hardwood stand, speaks to the need for allocation of more resources to engineering of creation and restoration projects prior to initiation and long-term monitoring that recognizes the early successional processes of bottomland hardwood forests, as opposed to intensive, short-term vegetation monitoring in the absence of scientifically justifiable criteria. Basically, except in cases of extreme drought or intensive ponding, regeneration will occur; the question becomes one of whether the site will be performing the desired functions as it matures. Planners must take into consideration such factors as the quantity and source of water available to the proposed project, the relationship between hydrology and geomorphology of the site, and how this will influence the natural colonization of the site. For example, if the goal of a project is to replace or restore a cypress swamp, considered for inclusion in the project should be deposition of topsoil from a cypress swamp being impacted elsewhere and an open hydrologic regime, accepting that the germination of cypress seedlings is subject to a certain amount of climatic stochasticity. The emphasis here is on ensuring that conditions are favorable to the development of a mature cypress swamp, while reducing the need for costly, and often unsuccessful, plantings and avoiding the imposition of monitoring requirements, such as seedling survival rates, that are not 
consistent with the natural development of the system. In another case, where the reestablishment of mast-producing species is a priority and mature specimens of the desired species may not be in close enough proximity to serve as an adequate seed source, the physical regime of sites should be allowed to stabilize through natural colonization. This would allow the natural variation in hydrologic regime related to evapotranspiration to reach an equilibrium and encourage the natural establishment of species optimally suited to microtopographic environmental gradients, increasing the efficiency of the project as well as the potential for desired species composition in the long rin. As the early successional colonizers begin to reach the end of their natural life span, fifteen to twenty years for $S$. nigra, then the progress of the site can be reevaluated and supplemental plantings can be pinpointed where they will enjoy the greatest chance of survival. Basically, these observations support the assertions by Mitsch and Wilson (1996) that mitigation projects must be allowed a greater amount of time before judgment of success or failure is attempted and that projects should be allowed a greater element of selfdesign. 


\section{Conclusion}

This study examined a chronosequence of recently clearcut forested wetlands for the purposes of determining whether these sites could serve as suitable reference wetlands for monitoring the success of created and restored wetlands. Several factors were found to significantly alter successional trajectories at the project sites and, in doing so, to greatly complicate any future attempts to use vegetative characteristics from clearcut forested wetlands to establish success criteria. First and foremost, the overwhelming presence of coppice regeneration on mixed hardwood sites results in an enhanced rate of vegetation community development that bears little resemblance to what could reasonably be expected at a created or restored site, even one where wetland soils were already present and appropriate species were planted. Even at the Willow and Cypress sites, where vegetation development following clearcut could be expected to more closely approximate that of a created or restored site, physical factors mitigate the usefulness of vegetative criteria. For example, at the seven-year-old Cypress site, it is clearly evident that the nearly continuous flooding has almost completely suppressed regeneration of woody species over the majority of the cleared area. It would be more appropriate, perhaps, to undertake monitoring of sites like the three-year-old-Cypress site and eight-year-old Willow site over longer time scales and only then try to elucidate the relationship between environmental characteristics and successional trajectory, rather than attempting to establish the relationship by coalescing data from substantially different sites representing a broad spectrum of ages.

This research also points to the need for research into the relationship between soils and early successional trajectory. While certain chemical characteristics were analyzed as part of this study, this aspect was extremely limited in scope and not comprehensive enough to support justifiable conclusions. More information is needed on how these characteristics change over 
time, as well as on the role of seed banks and organic soils in advancing regeneration. This, too, could be more effectively achieved through long-term monitoring of selected sites, as could a greater understanding of changes in hydrologic regime during the early stages of site development. 


\section{Literature Cited}

Allen, J.A. 1997. Reforestation of bottomland hardwoods and the issue of woody species diversity. Restoration Ecology 5(2): 125-134.

Austin, M.P. 1977. Use of ordination and other multivariate methods to study succession. Vegetatio 35(3): 165-175.

Beals, E.W. 1973. Ordination: mathematic elegance and ecological naivete. J. Ecol. 61: 23-35.

Beals, E.W. 1984. Bray-Curtis ordination: an effective strategy for analysis of multivariate ecological data. Advances in Ecological Research 14: 1-55.

Bitterlich, W. 1948. Die Winkelzählprobe. Allg. Forst- u. Holzwirtsch. Ztg. 59: 4-5.

Bowling, D.R., and R.C. Kellison. 1983. Bottomland hardwood stand development following clearcutting. Southern Journal of Applied Forestry 7:110-116.

Braun, J., and E. Furrer. 1913. Remarques sur l'étude des groupements de plantes. Soc. Languedoc. Geogr. Bull. 36:20-41. Pages 54-77 in R.P. McIntosh, ed. 1980. Phytosociology. Dowden, Hutchinson, and Ross: Stroudsburg, Penn.

Bray, J.R., and J.T. Curtis. 1957. An ordination of the upland forest communities of southern Wisconsin. Ecological Monographs 27: 325-349.

Brinson, M.M., A.E. Lugo, and S. Brown. 1981. Primary productivity, decomposition, and consumer activity in freshwater wetlands. Annual Review Ecol. and Systematics 12: 123-161.

Brinson, M.M., and R. Rheinhardt. 1996. The role of reference wetlands in functional assessment and mitigation. Ecological Applications 6(1): 69-76.

Brooks, R.P., and R.M. Hughes. 1986. Guidelines for assessing biotic communities of freshwater wetlands. Pages 276-282 in J.A. Kusler, M.L. Quammen, and G.Brooks, eds. Proceedings of the National Wetland Symposium: Mitigation of Impacts and Losses. ASWM Technical Report 3. Assoc. of State Wetland Managers: Berne, NY.

Causton, D.R. 1988. Introduction to vegetation analysis. Unwin Hyman: London. $342 \mathrm{pp}$.

Clements, F.E. 1916. Plant Succession. Carnegie Institution of Washington, Publ. 242. 512 pp.

Clewall, A.F., and R. Lea. 1990. Creation and restoration of forested wetland vegetation in the southeastern United States. Pages 195-231 in J.A. Kunsler and M.E. Kentula, eds. Wetland creation and restoration: the status of the science. Island Press, Washington, D.C.

Connell, J.H., and R.O. Slayter. 1977. Mechanisms of succession and their role in community 
stabilization and organization. The American Naturalist 111(982): 1119-1144.

Conner, W.H. 1994. Effect of forest management practices on southern forested wetland productivity. Wetlands 14(1): 27-40.

Costanza, R, S.C. Farber, and J. Maxwell. 1989. Valuation and management of wetland ecosystems. Ecological Economics 1: 335-361.

Cottam, G., and J.T. Curtis. 1956. The use of distance measures in phytosociological sampling. Ecology 34: 451-460.

Cowardin, L.M., V. Carter, F.C. Golet, and E.T. LaRoe. 1979. Classification of wetlands and deepwater habitats of the United States. U.S. Fish Wildl. Serv. Biol. Serv. Program FWS/OBS-79/31. Supt. of Documents, Washington, D.C. 103 pp.

Daubenmire, R.F. 1959. Canopy coverage methods of vegetation analysis. Northwest Sci. 33: 43-64.

Daubenmire. 1966. Vegetation: identification of typical communities. Science 151: 291-298.

Daubenmire. 1968. Plant communities: a text book of plant synecology. Harper and Row, New York.

Day, F.P., Jr. 1984. Biomass and litter accumulation in the Great Dismal Swamp. Pages 386392 in K.C. Ewel and H.T. Odum, ed. Cypress Swamps. University of Florida Press: Gainesville, Fla.

Doumlele, D.G., B.K. Fowler, and G.M. Silberhorn. 1985. Vegetative community structure of a tidal freshwater swamp in Virginia. Wetlands 4: 129-145.

Drury, W.H., and I.C.T. Nesbitt. 1973. Succession. J. Arnold Arbor. 54: 331-368.

Farber, S., and R. Costanza. 1987. The economic value of wetlands systems. J. Environmental Management 24: 41-51.

Fowler, B.K. 1987. Primary production and temporal variation in the macrophytic community of a tidal freshwater swamp. M.A. Thesis, College of William and Mary, School of Maarine Science, Gloucester Point, Virginia. $60 \mathrm{pp}$.

Gauch, H.G., Jr. 1982. Multivariate analysis in community ecology. Cambridge University Press, Cambridge, UK. 298 pp.

Gauch, H.G., and R.H. Whitaker. 1972. Comparison of ordination techniques. Ecology 53(5): 869-874.

Gauch, H.G., Jr., R.H. Whitaker, and T.R. Wentworth. 1977. A comparative study of reciprocal averaging and other ordination techniques. J. Ecol. 65: 157-174. 
Glascock, S., and S. Ware. 1979. Forests of small stream bottoms in the Peninsula of Virginia. Va. Jour. Sci. 30:17-21.

Gleason, H.A. 1917. The structure and development of the plant association. Bull. Torrey Bot. Club 44: 463-481.

Gleason, H.A. 1927. Further views on the succession concept. Ecology 8: 299-326.

Godfrey, R.K., and J.W. Wooten. 1981. Aquatic and wetland plants of southeastern United States: dicotyledons. University of Georgia Press, Athens, GA. 933 pp.

Goodall, D.W. 1954. Objective methods for the classfification of vegetation. III. An essay in the use of factor analysis. Australian Journal of Botany 2: 304-324.

Gosselink, J.G., and L.C. Lee. 1987. Cumulative impact assessment in bottomland hardwood forests. Center for Wetland Resources, Louisiana State University, Baton Rouge. LSUCEI-86-09. $113 \mathrm{pp}$.

Gresham, C.A. 1985. Clearcutting not enough for early establishment of desirable species in Santee River swamp. Southern Journal of Applied Forestry 9: 52-54.

Grosenbaugh, L.R. 1952. Plotless timber estimates - new, fast, easy. J. For.: 50: 32-37.

Hanks, J.P. 1971. Secondary succession and soils on the inner coastal plain of New Jersey. Bull. Torr. Bot. Soc. 98(6): 315-321.

Harris, L., and J.G. Gosselink. 1986. Cumulative impacts of bottomland hardwood conversion on hydrology, water quality, and terrestrial wildlife. U.S. Environmental Protection Agency, Washington, D.C. Unpubl. Report.

Harris, S.W., and W.H. Marshall. 1963. Ecology of water-level manipulations on a northern marsh. Ecology 44: 331-343.

Heeren, R.D. 1983. Harvesting and regeneration methods. p. 18-23 in Natural Regeneration Short Course. Cooperative Hardwood Research Program. N.C. State University: Raleigh, North Carolina.

Hill, M.O. 1973. Reciprocal averaging: an eigenvector method of ordination. J. Ecol. 61: 237249.

Hill, M.O., and H.G. Gauch. 1980. Detrended correspondence analysis: an improved ordination technique. Vegetatio 42: 47-58.

Horn, H.S. 1974. The ecology of secondary succession. Ann. Rev. Ecol. Syst. 5:25-37.

Horn, H.S. 1975. Forest succession. Sci. Am. 232 (5): 90-98.

Huenneke, L.R., and R.R. Sharitz. 1986. Microsite abundance and distribution of woody 
seedlings in a South Carolina cypress-tupelo swamp. Am. Midl. Nat. 115(20): 328-335.

Johnson, C.W., and R.L. Linder. 1986. An economic valuation of South Dakota wetlands as a recreation resource for resident hunters. Landscape Journal 5:33-38.

Johnson, W.B., C.E. Sasser, and J.G. Gosselink. 1985. Succession of vegetation in an evolving river delta, Atchafalaya, Louisiana. J. Ecol. 73: 973-986.

Jones, R.H., R.R. Sharitz, P.M. Dixon, D.S. Segal, R.L. Schneider. 1994. Woody plant regeneration in four floodplain forests. Ecological Monographs 64(3): 345-367.

Kessell, S.R., and R.H. Whitaker. 1976. Comparisons of three ordination techniques. Vegetatio 32(1): 21-29.

Küchler, A.W. 1964. Potential Natural Vegetation of the Conterminous United States. New York: American Geographical Society, Spe. Publ. 36.

Kusler, J.A. 1986. Wetland creation/restoration: a summary of science views and perspectives. Pages 440-446 in J.A. Kusler, M.L. Quammen, and G.Brooks, eds. Proceedings of the National Wetland Symposium: Mitigation of Impacts and Losses. ASWM Technical Report 3. Assoc. of State Wetland Managers: Berne, NY.

Landin, M.C., and J.W. Webb. 1986. Wetland development and restoration as part of Corps of Engineer programs. Pages 388-391 in J.A. Kusler, M.L. Quammen, and G.Brooks, eds. Proceedings of the National Wetland Symposium: Mitigation of Impacts and Losses. ASWM Technical Report 3. Assoc. of State Wetland Managers: Berne, NY.

Levy, G.F. 1976. Vegetation study at the Duck Field Research Facility, Duck, North Carolina. MR No. 76-6. U.S. Corps of Engineers, Coastal Engineering Research Center, Fort Belvoir, Va.

Levy, R. Harris, and J.E. Perry. 1984. Evaluation of vegetation dynamics at the Duck Field Research Facility, Duck, North Carolina. MR No. 84-3. U.S. Corps of Engineers, Coastal Engineering Research Center, Fort Belvoir, Va.

Mader, S.F. 1990. Recovery of ecosystem functions and community structure by a tupelocypress wetland following timber harvesting. North Carolina State University, Raleigh, NC. Ph.D. Thesis. $276 \mathrm{pp}$.

McCormick, I. 1968. Succession. Via 1:1-16

McKnight, J.S., and R.L. Johnson. 1975. Growing hardwoods in southern lowlands. Forest Farmer 34: 38-47.

Meeks, R.L. 1969. The effect of drawdown date on wetland plant succession. J. Wildl. Mgmt. 33: 817-821.

Menges, E.S. 1986.. Environmental correlates of herb species composition in five southern 
Wisconsin floodplain forests. Am. Midl. Nat. 115(1): 106-117.

Meuller-Dombois, D., and H. Ellenberg. 1974. Aims and Methods of Vegetation Ecology. John Wiley and Sons, New York. $547 \mathrm{pp}$.

Mitsch, W.J., and J.G. Gosselink. 1993. Wetlands. Van Nostrand Reinhold: New York, N.Y. $722 \mathrm{pp}$.

Mitsch, W.J., and R.F. Wilson. 1996. Improving the success of wetland restoration with knowhow, time, and self-design. Ecological Applications 6(1): 77-83.

Muir, T.A., C. Rhodes, and J.G. Gosselink. 1990. Federal statutes and programs relating to cumulative impacts in wetlands. Pages 223-236 in J.G. Gosselink, L.C. Lee, and T.A. Muir, eds. Ecological Processes and Cumulative Impacts: Illustrated by Bottomland Hardwood Wetland Ecosystems. Lewis Publishers: Chelsea, MI.

Megonigal, J.P., W.H. Conner, S. Kroeger, and R.R. Sharitz. 1997. Aboveground production in southeastern floodplain forests: a test of the subsidy-stress hypothesis. Ecology 78(2): 370-384.

Messina, M.G., S.H. Schoenholtz, M.W. Lowe, Z. Wang, D.K. Gunter, A.J. Londo. 1997. Initial responses of woody vegetation, water quality, and soils to harvesting intensity in a Texas bottomland hardwood ecosystem. Forest Ecology and Management 90(1997): 201-215.

Moss, C.E. 1910. The fundamental units of vegetation: historical development of the concepts of the plant association and plant formation. New Phytologist 9: 18-22, 26-41, 44-53. Pages 24-53 in R.P. McIntosh, ed. 1980. Phytosociology. Dowden, Hutchinson, and Ross: Stroudsburg, Penn.

Noon, K.F. 1996 A model of created wetland primary succession. Landscape and Urban planning 34: 97-123.

Odum, E.P. 1969. The strategy of ecosystem development. Science 142: 15-23.

Orloci, L. 1966. Geometric models in ecology. I. The theory and application of some ordination methods. J. Ecol. 54: 193-215.

Pavel, C.M. 1993. An assessment of timber harvesting on the biomass, species diversity, and stand structure of the vegetation in a South Carolina bottomland hardwood forest. M.S. Thesis, North Carolina State University, Raleigh, NC. 78 pp.

Pearsall, W.H. 1920. The aquatic vegetation of English lakes. J. Ecol. 8: 163-201.

Perry, J.E. 1991. Analysis of vegetation patterns in a tidal freshwater marsh. Ph.D. Dissertation, College of William and Mary, School of Marine Science, Gloucester Point, Va. $204 \mathrm{pp}$. 
Plunkett, G.M., and G.W. Hall. 1995. The vascular flora and vegetation of western Isle of Wight County, Virginia. Castanea 60(1): 30-59.

Rheinhardt, R.D., M.M. Brinson, and P.M. Farley. 1997. Applying wetland reference data to functional assessment, mitigation, and restoration. Wetlands 17(2): 195-215.

Rheinhardt, R.D. 1991. Vegetation ecology of tidal freshwater swamps of the lower Chesapeake Bay, USA. Ph.D. Dissertation, College of William and Mary, School of Marine Science, Gloucester Point, Va. 184 pp.

Silberhorn, G.M. 1992. A characterization of the plant community structure of palustrine forested wetlands in the coastal plain of Virginia. Pages 29-35 in Proceedings of a Workshop on Saturated Forested Wetlands in the Mid-Atlantic Region: The State of the Science, 29-31 January, 1992, Annapolis, Md.

Stubbs, J. 1973. Atlantic oak-gum-cypress. P. 89-93. In Silvicultural systems for the major forest types of the United States. U.S. Dept. of Agriculture, Agriculture Handbook No. 445 , Washington, DC, USA.

Taylor, J.R., M.A. Cardamome, and W.J. Mitsch. 1990. Bottomland hardwood forests: their functions and values. Pages 13-86 in J.G. Gosselink, L.C. Lee, and T.A. Muir, editors. Ecological processes and cuculative impacts: illustrated by bottomland hardwood wetland ecosystems. Lewis, Chelsea, Michigan, USA.

ter Braak, C.J.F. 1985. Correspondence analysis of incidence and abundance data: properties in terms of a unimodal response model. Biometrics 41: 859-873.

ter Braak, C.J.F. 1986. Canonical correspondence analysis: a new eigenvector technique for multivariate direct gradient analysis. Ecology 67: 1167-1179.

ter Braak, C.J.F. 1988. CANOCO: a FORTRAN program for Canonical Community Ordination by partial canonical correspondence analysis, Principle Components Analysis, and Redundancy Analysis (version 3.1). Agricultural Mathematics Group. Wagen ingen, The Netherlands.

Tilman, D. 1988. Plant Strategies and the Dynamics and Structure of Plant Communities. Princeton University Press: Princeton, New Jersey. 360 pp.

Tiner, R.W., I. Kenenski, T. Nuerminger, J. Eaton, D.B. Foulis, G. Smith, and W.E. Frayer. 1994. Recent status and trends in the Chesapeake watershed (1982-1989): Technical report. U.S. Environmental Protection Agency for the Chesapeake Bay Program. Annapolis, MA. $69 \mathrm{pp}$.

van der Valk, A.G. 1981. Succession in wetlands: a Gleasonian approach. Ecology 62(3): 688696. 
van der Valk, A.G. 1982. Succession in temperate North American wetlands. Pages 169-179 in B. Gopal, R.E. Turner, R.G. Wetzel, and D.F. Whigham, eds. Wetlands: Ecology and Management. National Institute of Ecology: Jaipur, India.

Warming, E. 1909. Oecology of Plants. Clarendon Press: Oxford. 422 pp.

Weaver, J.E., and F.E. Clements. 1938. Plant Ecology. 2nd Ed. McGraw-Hill: New York. 601 pp.

Wharton, C.H. W.M. Kitchens, E.C. Pendleton, and T.W. Sipe. 1982. The ecology of bottomland hardwood swamps of the Southeast: a community profile. Biological Report FWS/OBS-81/37. U.S. Fish and Wildlife Service, Washington, D.C.

Wilson, L.R. 1935. Lake development and plant succession in Vilas County, Wisconsin. Part 1. The medium hard water lakes. Ecol. Monogr. 5: 207-247. 
Appendix 
Figure 1. Locations of project sites.

Figure 2. Canonical correspondence analysis of all project sites with no covariables. Vegetation data includes understory and overstory importance values for each species recorded in those strata (i.e. two values may exist for each species). Environmental variables included information related to hydrologic regime, soil chemistry, and stem origin. Only those environmental variables exhibiting the highest correlation with ordination results are depicted by arrows in the figure. Org $\mathrm{C}=$ organic carbon; Flood = duration of flooding as a percentage of the calendar year; $\mathrm{O}$ Cop = percentage of overstory stems originating as coppice. The dashed line encloses the only site in which Platanus occidentalis exhibited an overstory importance value greater than 75 .

Figure 3. Canonical correspondence analysis with Site $2 \mathrm{~b}$ removed and no covariables; other covariables identical to Figure 2 . U-Cop $=$ percentage of understory stems originating as coppice. The upper dashed line encloses those sites in which Salix nigra exhibited an overstory importance value greater than 50. The lower dashed line encloses those sites in which Taxodium distichum exhibits an understory importance value greater than 30 .

Figure 4. Canonical correspondence analysis with Site $2 \mathrm{~b}$ removed from the ordination and age inserted as a covariable. The dashed line to the right encloses those sites in which Taxodium distichum exhibits an understory importance value greater than 45 . The dashed line to the left encloses those sites in which Taxodium distichum exhibits an understory importance value less than 6. 
Site \# - $2 \mathrm{a}$

Location (Coordinates) - 36043'00 76049'15"

Owner and Contact - J.D. \& Sarah Wright

Nearest Stream -Beaver Dam swamp

River Basin - Blackwater

NWI Classification - PF01A

Approximate Size of Site - 49 acres

Age of Site - 2

\begin{tabular}{|c|c|c|c|c|c|}
\hline $\begin{array}{l}\text { Site } 2 \mathrm{a} \\
\text { herbaceous }\end{array}$ & $\begin{array}{l}\text { Mean } \\
\text { Cover }\end{array}$ & $\begin{array}{l}\text { Relative } \\
\text { Dom }\end{array}$ & $\begin{array}{l}\text { Density/ } \\
0.5 \mathrm{~m}^{\wedge} 2\end{array}$ & $\begin{array}{l}\text { Relative } \\
\text { Density }\end{array}$ & $\begin{array}{l}\text { Importanc } \\
\text { Values }\end{array}$ \\
\hline Total & 115.66 & 1. & 308.2 & 1 & \\
\hline Juncus effusus & 24.52 & 0.212001 & 153.6 & 0.498378 & 0.355189 \\
\hline Leersia virginica & 23 & 0.198859 & 89.8 & 0.291369 & 0.245114 \\
\hline Murdania keisak & 18.5 & 0.159952 & 33.2 & 0.107722 & 0.133837 \\
\hline Lonicera spp & 7 & 0.060522 & 4 & 0.012979 & 0.03675 \\
\hline Zizaniopsis milacea & 7.5 & 0.064845 & 1.8 & 0.00584 & 0.035343 \\
\hline Typha spp & 6.02 & 0.052049 & 2.2 & 0.007138 & 0.029594 \\
\hline Acer rubrum & 4 & 0.034584 & 2.8 & 0.009085 & 0.021835 \\
\hline Toxicodendron radicans & 3.02 & 0.026111 & 2.2 & 0.007138 & 0.016625 \\
\hline$* * *$ & 3 & 0.025938 & 2 & 0.006489 & 0.016214 \\
\hline Bochmeria cylindrica & 3.5 & 0.030261 & 0.6 & 0.001947 & 0.016104 \\
\hline$* * *$ & 3 & 0.025938 & 1 & 0.003245 & 0.014591 \\
\hline$* * *$ & 3.02 & 0.026111 & 0.8 & 0.002596 & 0.014353 \\
\hline Mikania scandens & 3 & 0.025938 & 0.6 & 0.001947 & 0.013942 \\
\hline Arundinaria gigantea & 3 & 0.025938 & 0.4 & 0.001298 & 0.013618 \\
\hline Eleocharis obtusa & 0.02 & 0.000173 & 7 & 0.022713 & 0.011443 \\
\hline$* * *$ & 0.5 & 0.004323 & 1.8 & 0.00584 & 0.005082 \\
\hline Platanus occidentalis & 1 & 0.008646 & 0.4 & 0.001298 & 0.004972 \\
\hline$* * *$ & 0.5 & 0.004323 & 1.4 & 0.004543 & 0.004433 \\
\hline Carex lurida & 0.5 & 0.004323 & 0.6 & 0.001947 & 0.003135 \\
\hline *** & 0.5 & 0.004323 & 0.4 & 0.001298 & 0.00281 \\
\hline$* * *$ & 0.5 & 0.004323 & 0.2 & 0.000649 & 0.002486 \\
\hline *** & 0.02 & 0.000173 & 1 & 0.003245 & 0.001709 \\
\hline Alnus rugosa & 0.02 & 0.000173 & 0.2 & 0.000649 & 0.000411 \\
\hline *** & 0.02 & 0.000173 & 0.2 & 0.000649 & 0.000411 \\
\hline
\end{tabular}

*** - unidentified species 
Site 2a

understory

Total

Salix nigra

Fraxinus spp

Acer rubrum

Alnus rugosa

Platanus occidentalis

Liquidambar styraciflua

Liriodendron tulipifera

Rubus spp

Nyssa sylvatica

Magnolia virginiana

Pinus taeda

Site 2A

overstory

Total

Salix nigra
Meter^2/ Relative

Hectare Dom
Density/ Hectare
Relative

Density

Percent Importanc

Sprouts Values

$\begin{array}{lrrrrrr}1.995697 & 1 & 14720 & 1 & 0.380435 & 1 \\ & & & & & \\ 1.573938 & 0.788666 & 6000 & 0.407609 & 0.653333 & 0.598137 \\ 0.164541 & 0.082448 & 2240 & 0.152174 & 0 & 0.117311 \\ 0.124093 & 0.06218 & 2000 & 0.13587 & 0.76 & 0.099025 \\ 0.023562 & 0.011806 & 2080 & 0.141304 & 0 & 0.076555 \\ 0.044768 & 0.022432 & 560 & 0.038043 & 0.285714 & 0.030238 \\ 0.011781 & 0.005903 & 800 & 0.054348 & 0 & 0.030126 \\ 0.017279 & 0.008658 & 400 & 0.027174 & 0 & 0.017916 \\ 0.002356 & 0.001181 & 240 & 0.016304 & 0 & 0.008742 \\ 0.006676 & 0.003345 & 160 & 0.01087 & 0 & 0.007107 \\ 0.014137 & 0.007084 & 80 & 0.005435 & 0 & 0.006259 \\ 0.006283 & 0.003148 & 80 & 0.005435 & 0 & 0.004292 \\ 0.006283 & 0.003148 & 80 & 0.005435 & 0 & 0.004292\end{array}$

Meter 2/ Relative Density/ Relative Percent Importanc Hectare Dom Hectare Density Sprouts Values

$\begin{array}{llllll}0.182605 & 1 & 320 & 1 & 0 & 1\end{array}$

$\begin{array}{llllll}0.182605 & 1 & 320 & 1 & 0 & 1\end{array}$

*** - unidentified species 
Site \# - 2b

Location (Coordinates) $-36052^{\prime} 40^{\prime \prime} 76051^{\prime} 00^{\prime \prime}$

Owner and Contact - Matney Timber

Nearest Stream - Tucker Swamp

River Basin - Blackwater River

NWI Classification -

Approximate Size of Site - 10 acres

Age of Site - 2

Site $\mathbf{2 b}$

herbaceous

$\begin{array}{lllll}\text { Mean } & \text { Relative } & \text { Density/ } & \text { Relative } & \text { Importanc } \\ \text { Cover } & \text { Dom } & 0.5 \mathrm{~m}^{\wedge} 2 & \text { Density } & \text { Values }\end{array}$

Total

111.62

1

259

1

1

***

Salix nigra

***

Scirpus cyperinus

Juncus effusus

Saururus cernuus

Typha angustifolia

Scirpus americanus

Boehmeria cylindrica

***

$\begin{array}{ll}7.5 & 0.067192\end{array}$

$\begin{array}{lll}200 & 0.772201 & 0.419697\end{array}$

$\begin{array}{ll}24.52 & 0.219674\end{array}$

$\begin{array}{llll}0.4 & 0.001544 & 0.110609\end{array}$

$\begin{array}{ll}23 & 0.206056\end{array}$

$\begin{array}{rr}18.5 & 0.165741\end{array}$

$\begin{array}{ll}0.5 & 0.004479\end{array}$

$\begin{array}{llll}0.6 & 0.002317 & 0.104186\end{array}$

$\begin{array}{lll}0.4 & 0.001544 & 0.083643\end{array}$

$\begin{array}{ll}7 & 0.062713\end{array}$

$\begin{array}{llll}27 & 0.104247 & 0.054363\end{array}$

$\begin{array}{ll}6.02 & 0.053933\end{array}$

$\begin{array}{lll}1.2 & 0.004633 & 0.033673\end{array}$

$\begin{array}{llll}1.6 & 0.006178 & 0.030055\end{array}$

$\begin{array}{ll}3 & 0.026877\end{array}$

$\begin{array}{llll}5.8 & 0.022394 & 0.024635\end{array}$

$\begin{array}{ll}4 & 0.035836\end{array}$

Impatiens capensis -

$\begin{array}{ll}0.5 & 0.004479\end{array}$

$\begin{array}{ll}3.4 & 0.013127\end{array}$

0.024482

3.50 .031356

3.020 .027056

$\begin{array}{ll}3 & 0.026877\end{array}$

***

Fraxinus spp

*\$*

$\begin{array}{ll}3 & \mathbf{0 . 0 2 6 8 7 7}\end{array}$

Lonicera spp

Taxodium distichum

Campsis radicans

Eupatorium spp.

$3.02 \quad 0.027056$

$0.02 \quad 0.000179$

$\begin{array}{ll}1 & 0.008959\end{array}$

$\begin{array}{ll}0.5 & 0.004479\end{array}$

$0.02 \quad 0.000179$

$\begin{array}{lll}11.2 & 0.043243 & 0.023861\end{array}$

$\begin{array}{lll}1 & 0.003861 & 0.017609\end{array}$

$\begin{array}{llll}1 & 0.003861 & 0.015459\end{array}$

$\begin{array}{llll}0.6 & 0.002317 & 0.014597\end{array}$

$\begin{array}{llll}0.4 & 0.001544 & 0.014211\end{array}$

$\begin{array}{llll}0.2 & 0.000772 & 0.013914\end{array}$

$\begin{array}{llll}2.8 & 0.010811 & 0.005495\end{array}$

$\begin{array}{lll}0.2 & 0.000772 & 0.004866\end{array}$

$\begin{array}{lll}1 & 0.003861 & 0.00417\end{array}$

$\begin{array}{lll}0.2 & 0.000772 & 0.000476\end{array}$

*** - unidentified species 


\begin{tabular}{|c|c|c|c|c|c|c|}
\hline $\begin{array}{l}\text { Site } 2 \mathrm{~b} \\
\text { understory }\end{array}$ & $\begin{array}{l}\text { Meter^2/ } \\
\text { Hectare }\end{array}$ & $\begin{array}{l}\text { Relative } \\
\text { Dom }\end{array}$ & $\begin{array}{l}\text { Density/ } \\
\text { Hectare }\end{array}$ & $\begin{array}{l}\text { Relative } \\
\text { Density }\end{array}$ & $\begin{array}{l}\text { Percent } \\
\text { Sprouts }\end{array}$ & $\begin{array}{l}\text { Importanc } \\
\text { Values }\end{array}$ \\
\hline Total & 1.006488 & 1 & 9600 & 1 & 0.291667 & 1 \\
\hline Fraxinus spp & 0.283921 & 0.282091 & 2960 & 0.308333 & 0.864865 & 0.295212 \\
\hline Platanus occidentalis & 0.312588 & 0.310574 & 1680 & 0.175 & 0.619048 & 0.242787 \\
\hline Salix nigra & 0.097782 & 0.097152 & 1840 & 0.191667 & 0 & 0.144409 \\
\hline Liquidambar styraciflua & 0.140586 & 0.13968 & 1280 & 0.133333 & 0 & 0.136507 \\
\hline Taxodium distichum & 0.100924 & 0.100273 & 960 & 0.1 & 1 & 0.100137 \\
\hline Magnolia virginiana & 0.060868 & 0.060476 & 720 & 0.075 & $\mathbf{0}$ & 0.067738 \\
\hline Acer rubrum & 0.006283 & 0.006243 & 80 & 0.008333 & 0 & 0.007288 \\
\hline *** & 0.003534 & 0.003512 & 80 & 0.008333 & 0 & 0.005922 \\
\hline $\begin{array}{l}\text { Site } 2 \mathrm{~b} \\
\text { overstory }\end{array}$ & $\begin{array}{l}\text { Meter`2/ } \\
\text { Hectare }\end{array}$ & $\begin{array}{l}\text { Relative } \\
\text { Dom }\end{array}$ & $\begin{array}{l}\text { Density/ } \\
\text { Hectare }\end{array}$ & $\begin{array}{l}\text { Relative } \\
\text { Density }\end{array}$ & $\begin{array}{l}\text { Percent } \\
\text { Sprouts }\end{array}$ & $\begin{array}{l}\text { Importanc } \\
\text { Values }\end{array}$ \\
\hline Total & & 1 & & 1 & 0.75 & 1 \\
\hline $\begin{array}{l}\text { Platanus occidentalis } \\
* * *\end{array}$ & 0.160614 & 0.771698 & 240 & 0.75 & 1 & 0.760849 \\
\hline$* * *$ & 0.047517 & 0.228302 & 80 & 0.25 & $\mathbf{0}$ & 0.239151 \\
\hline
\end{tabular}


Site \# -3a

Location (Coordinates) - 36041'44" 77002'30"

Owner and Contact -Jimmy Willis - Curtis Johnson

Nearest Stream -Nottaway Swamp

River Basin - Nottaway River

NWI Classification - PF01A

Approximate Size of Site - $\mathbf{3 8}$ acres

Age of Site - 3

Site 3a

herbaceous

Total

Eleocharis spp

Juncus effusus

Ludwigia decurrens

Carex lurida

Hydrocotyle umbellata

Ludwigia palustris

Murdania keisak

Arundinaria gigantea

Scirpus americanus

Erechtites hieraciifolia

Ptilimnium capillaceum

***

***

Polygonum spp

***

Hypericum virginicum

***

***

Cephalanthus occidentalis

Proserpinaca palustris

Boehmeria cylindrica

Parthenocissus quinquefolia

Diospyros virginiana

Eupatorium perfoliatum

***

Typha spp

Bidens coronata

Taxodium distichum

Poaceae spp

\begin{tabular}{|c|c|c|c|c|}
\hline $\begin{array}{l}\text { Mean } \\
\text { Cover }\end{array}$ & $\begin{array}{l}\text { Relative } \\
\text { Dom }\end{array}$ & $\begin{array}{l}\text { Density/ } \\
0.5 \mathrm{~m}^{\wedge} 2\end{array}$ & $\begin{array}{l}\text { Relative } \\
\text { Density }\end{array}$ & $\begin{array}{l}\text { Importanc } \\
\text { Values }\end{array}$ \\
\hline 61.16667 & 0.997283 & 0.033243 & 1.006749 & 1.002016 \\
\hline 1.333333 & 0.021739 & 0.000725 & 0.241282 & 0.131511 \\
\hline 2.333333 & 0.038043 & 0.001268 & 0.149606 & 0.093825 \\
\hline 7.5 & 0.122283 & 0.004076 & 0.040495 & 0.081389 \\
\hline 6.5 & 0.105978 & 0.003533 & 0.047807 & 0.076892 \\
\hline 2.666667 & 0.043478 & 0.001449 & 0.084364 & 0.063921 \\
\hline 3.5 & 0.057065 & 0.001902 & 0.055681 & 0.056373 \\
\hline 3.5 & 0.057065 & 0.001902 & 0.054556 & 0.05581 \\
\hline 4.5 & 0.07337 & 0.002446 & 0.029809 & 0.051589 \\
\hline 4.666667 & 0.076087 & 0.002536 & 0.01631 & 0.046199 \\
\hline 3.5 & 0.057065 & 0.001902 & 0.025872 & 0.041469 \\
\hline 1.166667 & 0.019022 & 0.000634 & 0.061305 & 0.040163 \\
\hline 2.5 & 0.040761 & 0.001359 & 0.026434 & 0.033598 \\
\hline & 0.016304 & 0.000543 & 0.032058 & 0.024181 \\
\hline 1.666667 & 0.027174 & 0.000906 & 0.012936 & 0.020055 \\
\hline 1.166667 & 0.019022 & 0.000634 & 0.01856 & 0.018791 \\
\hline 2 & 0.032609 & 0.001087 & 0.003375 & 0.017992 \\
\hline 1 & 0.016304 & 0.000543 & $0: 019123$ & 0.017713 \\
\hline 1 & 0.016304 & 0.000543 & 0.01631 & 0.016307 \\
\hline 0.166667 & 0.002717 & $9.06 \mathrm{E}-05$ & 0.021372 & 0.012045 \\
\hline 1.166667 & 0.019022 & 0.000634 & 0.003937 & 0.011479 \\
\hline 1 & 0.016304 & 0.000543 & 0.006187 & 0.011246 \\
\hline 1 & 0.016304 & 0.000543 & 0.005062 & 0.010683 \\
\hline 1 & 0.016304 & 0.000543 & 0.00225 & 0.009277 \\
\hline 1 & 0.016304 & 0.000543 & 0.000562 & 0.008433 \\
\hline 1 & 0.016304 & 0.000543 & 0.000562 & 0.008433 \\
\hline 0.5 & 0.008152 & 0.000272 & 0.003375 & 0.005763 \\
\hline 0.333333 & 0.005435 & 0.000181 & 0.005624 & 0.00553 \\
\hline 0.5 & 0.008152 & 0.000272 & 0.00225 & 0.005201 \\
\hline 0.166667 & 0.002717 & $9.06 \mathrm{E}-05$ & 0.004499 & 0.003608 \\
\hline 0.166667 & 0.002717 & $9.06 \mathrm{E}-05$ & 0.003937 & 0.003327 \\
\hline
\end{tabular}


Rhexia mariana

Penthorum sedoides

Hypericum mutilum

Lobelia puberula

Eupatorium capillifolium

Lonicera japonica

Betula nigra

Acer rubrum

Dirca palustris

Populus heterophylla $\begin{array}{llllll}0.166667 & 0.002717 & 9.06 \mathrm{E}-05 & 0.003375 & 0.003046\end{array}$

$\begin{array}{llllll}0.166667 & 0.002717 & 9.06 \mathrm{E}-05 & 0.001687 & 0.002202\end{array}$

$\begin{array}{llllll}0.166667 & 0.002717 & 9.06 \mathrm{E}-05 & 0.001125 & 0.001921\end{array}$

$\begin{array}{llllll}0.166667 & 0.002717 & 9.06 \mathrm{E}-05 & 0.001125 & 0.001921\end{array}$

$\begin{array}{llllll}0.166667 & 0.002717 & 9.06 \mathrm{E}-05 & 0.001125 & 0.001921\end{array}$

$\begin{array}{llllll}0.166667 & 0.002717 & 9.06 \mathrm{E}-05 & 0.000562 & 0.00164\end{array}$

$\begin{array}{lllll}0.166667 & 0.002717 & 9.06 \mathrm{E}-05 & 0.000562 & 0.00164\end{array}$

$\begin{array}{lllll}0.166667 & 0.002717 & 9.06 \mathrm{E}-05 & 0.000562 & 0.00164\end{array}$

$\begin{array}{lllll}0.166667 & 0.002717 & 9.06 \mathrm{E}-05 & 0.000562 & 0.00164\end{array}$

$\begin{array}{llllll}0.166667 & 0.002717 & 9.06 \mathrm{E}-05 & 0.000562 & 0.00164\end{array}$

*** - unidentified species 


$\begin{array}{lllrrrrr}\begin{array}{l}\text { Site 3a } \\ \text { understory }\end{array} & \begin{array}{l}\text { Meter^2/ } \\ \text { Hectare }\end{array} & \begin{array}{l}\text { Relative } \\ \text { Dom }\end{array} & \begin{array}{l}\text { Density/ } \\ \text { Hectare }\end{array} & \begin{array}{l}\text { Relative } \\ \text { Density }\end{array} & \begin{array}{l}\text { Percent } \\ \text { Sprouts }\end{array} & \begin{array}{l}\text { Importanc } \\ \text { Values }\end{array} \\ \text { Total } & 0.650179 & & 1 & 10293.33 & 1 & 0.023316 & 1 \\ \text { Taxodium distichum } & 0.353429 & 0.543588 & 6666.667 & 0.647668 & 0.032 & 0.595628 \\ \text { Liquidambar styraciflua } & 0.097389 & 0.149789 & 1280 & 0.124352 & 0 & 0.13707 \\ \text { Diospyros virginiana } & 0.052098 & 0.080129 & 880 & 0.085492 & 0.030303 & 0.082811 \\ \text { Salix nigra } & 0.043066 & 0.066237 & 533.3333 & 0.051813 & 0 & 0.059025 \\ \text { Populus heterophylla } & 0.035736 & 0.054963 & 106.6667 & 0.010363 & 0 & 0.032663 \\ \text { Myrica cerifera } & 0.030631 & 0.047111 & 80 & 0.007772 & 0 & 0.027441 \\ \text { *** } & 0.006414 & 0.009865 & 293.3333 & 0.028497 & 0 & 0.019181 \\ \text { Clethra alnifolia } & 0.005629 & 0.008657 & 186.6667 & 0.018135 & 0 & 0.013396 \\ \text { Pinus taeda } & 0.01165 & 0.017918 & 53.33333 & 0.005181 & 0 & 0.01155 \\ \text { Acer rubrum } & 0.007461 & 0.011476 & 80 & 0.007772 & 0 & 0.009624 \\ \text { Cephalanthus occidentalis } & 0.003272 & 0.005033 & 53.33333 & 0.005181 & 0 & 0.005107 \\ \text { *** } & 0.002094 & 0.003221 & 26.66667 & 0.002591 & 0 & 0.002906 \\ \text { Quercos phellos } & 0.001178 & 0.001812 & 26.66667 & 0.002591 & 0 & 0.002201 \\ \text { Platanus 0ccidentalis } & 0.000131 & 0.000201 & 26.66667 & 0.002591 & 0 & 0.001396\end{array}$

Site $3 a$ - no overstory

*** - unidentified species 
Site \# - 3b

Location (Coordinates) - $36^{\circ} 39^{\prime} 41^{\prime \prime} \mathrm{W} 77^{\circ} 28^{\prime} 27^{\prime \prime}$

Owner and Contact - Union Camp (experimental site)

Nearest Stream - Meherrin River

River Basin - Meherrin River

NWI Classification -

Approximate Size of Site - 160 acres

Age of Site - 3 years

Site 3b

herbaceous

Total

Polygonum punctatum

Toxicodendron radicans

Commelina virginica

Boehmeria cylindrica

Campsis radicans

***

***

Lysimachia nummularia

Cephalanthus occidentalis

Carex lurida

***

***

***

Commelina commelina

***

Lycopus virginicus

*** $\begin{array}{lllll}\text { Mean } & \text { Relative } & \text { Density/ } & \text { Relative } & \text { Importanc } \\ \text { Cover } & \text { Dom } & 0.5 \mathrm{~m}^{\wedge} 2 & \text { Density } & \text { Values }\end{array}$

$\begin{array}{lllll}67.6 & 1 & 73.8 & 1 & 1\end{array}$

$\begin{array}{ll}15.5 & 0.22929\end{array}$

$\begin{array}{ll}16 & 0.236686\end{array}$

$\begin{array}{ll}15.5 & 0.22929\end{array}$

$\begin{array}{ll}14 & 0.207101\end{array}$

$\begin{array}{ll}3 & 0.044379\end{array}$

$\begin{array}{ll}0.5 & 0.007396\end{array}$

0.50 .007396

$0.5 \quad 0.007396$

$0.5 \quad 0.007396$

$\begin{array}{ll}0.5 & 0.007396\end{array}$

$0.5 \quad 0.007396$

$0.5 \quad 0.007396$

$0.02 \quad 0.000296$

$0.02 \quad 0.000296$

$0.02 \quad 0.000296$

$0.02 \quad 0.000296$

0.020 .000296

$\begin{array}{rrr}38.4 & 0.520325 & 0.374808 \\ 8.8 & 0.119241 & 0.177964 \\ 7.4 & 0.100271 & 0.16478 \\ 6.4 & 0.086721 & 0.146911 \\ 1.4 & 0.01897 & 0.031674 \\ 2.8 & 0.03794 & 0.022668 \\ 2.4 & 0.03252 & 0.019958 \\ 2 & 0.0271 & 0.017248 \\ 1 & 0.01355 & 0.010473 \\ 1 & 0.01355 & 0.010473 \\ 0.8 & 0.01084 & 0.009118 \\ 0.4 & 0.00542 & 0.006408 \\ 0.4 & 0.00542 & 0.002858 \\ 0.2 & 0.00271 & 0.001503 \\ 0.2 & 0.00271 & 0.001503 \\ 0.2 & 0.00271 & 0.001503 \\ 0 & 0 & 0.000148\end{array}$

*** - unidentified species 


\begin{tabular}{|c|c|c|c|c|c|c|}
\hline $\begin{array}{l}\text { Site 3b } \\
\text { understory }\end{array}$ & $\begin{array}{l}\text { Meter^2/ } \\
\text { Hectare }\end{array}$ & $\begin{array}{l}\text { Relative } \\
\text { Dom }\end{array}$ & $\begin{array}{l}\text { Density/ } \\
\text { Hectare }\end{array}$ & $\begin{array}{l}\text { Relative } \\
\text { Density }\end{array}$ & $\begin{array}{l}\text { Percent } \\
\text { Sprouts }\end{array}$ & $\begin{array}{l}\text { Importanc } \\
\text { Values }\end{array}$ \\
\hline Total & 4.210127 & 1 & 16320 & 1 & 0.107843 & 1 \\
\hline Cephalanthus occidentalis & 2.745359 & 0.652085 & 9440 & 0.578431 & 0.076271 & 0.615258 \\
\hline Fraxinus spp. & 0.733169 & 0.174144 & 2720 & 0.166667 & 0.176471 & 0.170405 \\
\hline Salix nigra & 0.590619 & 0.140285 & 2560 & 0.156863 & 0.21875 & 0.148574 \\
\hline Platanus occidentalis & 0.098175 & 0.023319 & 960 & 0.058824 & 0 & 0.041071 \\
\hline Liquidambar styraciflua & 0.031416 & 0.007462 & 400 & 0.02451 & $\mathbf{0}$ & 0.015986 \\
\hline Populus heterophylla & 0.007854 & 0.001865 & 160 & 0.009804 & $\mathbf{0}$ & 0.005835 \\
\hline Liriodendron tulipifera & 0.003534 & 0.000839 & 80 & 0.004902 & $\mathbf{0}$ & 0.002871 \\
\hline $\begin{array}{l}\text { Site 3b } \\
\text { overstory }\end{array}$ & $\begin{array}{l}\text { Meter^2/ } \\
\text { Hectare }\end{array}$ & $\begin{array}{l}\text { Relative } \\
\text { Dom }\end{array}$ & $\begin{array}{l}\text { Density/ } \\
\text { Hectare }\end{array}$ & $\begin{array}{l}\text { Relative } \\
\text { Density }\end{array}$ & $\begin{array}{l}\text { Percent } \\
\text { Sprouts }\end{array}$ & $\begin{array}{l}\text { Importanc } \\
\text { Values }\end{array}$ \\
\hline Total & 1.03162 & 1 & 1280 & 1 & 0.4375 & \\
\hline Salix ni & 0.559989 & 0.542825 & 800 & 0.625 & 0.4 & 0.583912 \\
\hline Fraxinus spp & 0.432362 & 0.419109 & 400 & 0.3125 & 0.6 & 0.365805 \\
\hline *** & 0.03927 & 0.038066 & 80 & 0.0625 & 0 & 0.050283 \\
\hline
\end{tabular}

*** - unidentified species 
Site \# -5a

Location (Coordinates) -

Owner and Contact - Union Camp

Nearest Stream - Potecasi Creek

River Basin - Chowan River

NWI Classification -

Approximate Size of Site - 18 acres

Age of Site - 5

Site 5a

herbaceous

Total

Murdania keisak

Juncus effusus

Boehmeria cylindrica

Impatiens capensis

Carex spp.

Toxicodendron radicans

Lonicera spp.

Saururus cernuus

Campsis radicans

Ampelopsis cordata

Hypericum walteri

***

Parthenocissus quinquefolia

Platanus occidentalis

Smilax spp.

***

Galium obtusum

Carex stricta

***

***

Acer rubrum

\begin{tabular}{|c|c|c|c|c|}
\hline $\begin{array}{l}\text { Mean } \\
\text { Cover }\end{array}$ & $\begin{array}{l}\text { Relative } \\
\text { Dom }\end{array}$ & $\begin{array}{l}\text { Density/ } \\
0.5 \mathrm{~m}^{\wedge} 2\end{array}$ & $\begin{array}{l}\text { Relative } \\
\text { Density }\end{array}$ & $\begin{array}{l}\text { Importanc } \\
\text { Values }\end{array}$ \\
\hline 85.45714 & 1 & 364.7143 & 1 & 1 \\
\hline 46.07143 & 0.539117 & 302.4286 & 0.829221 & 0.684169 \\
\hline 8.214286 & 0.096122 & 35 & 0.095966 & 0.096044 \\
\hline 10.35714 & 0.121197 & 3.285714 & 0.009009 & 0.065103 \\
\hline 5.357143 & 0.062688 & 3.428571 & 0.009401 & 0.036044 \\
\hline .142857 & 0.025075 & 10.42857 & 0.028594 & 0.026835 \\
\hline 2.5 & 0.029254 & 2.857143 & 0.007834 & 0.018544 \\
\hline 2.5 & 0.029254 & 1.142857 & 0.003134 & 0.016194 \\
\hline 142857 & 0.025075 & 1.285714 & 0.003525 & 0.0143 \\
\hline 2.142857 & 0.025075 & 1.142857 & 0.003134 & 0.014104 \\
\hline 2.142857 & 0.025075 & 0.428571 & 0.001175 & 0.013125 \\
\hline 0.357143 & 0.004179 & 0.285714 & 0.000783 & 0.002481 \\
\hline 0.357143 & 0.004179 & 0.285714 & 0.000783 & 0.002481 \\
\hline 0.357143 & 0.004179 & 0.285714 & 0.000783 & 0.002481 \\
\hline 0.357143 & 0.004179 & 0.142857 & 0.000392 & 0.002235 \\
\hline 0.357143 & 0.004179 & 0 & 0 & 0.00209 \\
\hline 0.014286 & 0.000167 & 0.571429 & 0.001567 & 0.000867 \\
\hline 0.014286 & 0.000167 & 0.571429 & 0.001567 & 0.000857 \\
\hline 0.028571 & 0.000334 & 0.428571 & 0.001175 & 0.000755 \\
\hline 0.014286 & 0.000167 & 0.428571 & 0.001175 & 0.000671 \\
\hline 0.014286 & 0.000167 & 0.142857 & 0.000392 & 0.000279 \\
\hline 0.014286 & 0.000167 & 0.142857 & 0.000392 & 0.000279 \\
\hline
\end{tabular}

*** - unidentified species 


\begin{tabular}{|c|c|c|c|c|c|c|}
\hline $\begin{array}{l}\text { site 5a } \\
\text { understory }\end{array}$ & $\begin{array}{l}\text { Meter^2/ } \\
\text { Hectare }\end{array}$ & $\begin{array}{l}\text { Relative } \\
\text { Dom }\end{array}$ & $\begin{array}{l}\text { Density/ } \\
\text { Hectare }\end{array}$ & $\begin{array}{l}\text { Relative } \\
\text { Density }\end{array}$ & $\begin{array}{l}\text { Percent } \\
\text { Sprouts }\end{array}$ & $\begin{array}{l}\text { Importanc } \\
\text { Values }\end{array}$ \\
\hline Total & 1.066178 & 1 & 6685.714 & 1 & 0.538462 & 1 \\
\hline Salix nigra & 0.333233 & 0.312549 & 3085.714 & 0.461538 & 0.648148 & 0.387044 \\
\hline Taxodium distichum & 0.202521 & 0.18995 & 971.4286 & 0.145299 & 0.882353 & 0.167625 \\
\hline Acer rubrum & 0.169422 & 0.158906 & 457.1429 & 0.068376 & 1 & 0.113641 \\
\hline *** & 0.14025 & 0.131544 & 342.8571 & 0.051282 & 0 & 0.091413 \\
\hline Liquidambar styraciflua & 0.095931 & 0.089976 & 457.1429 & 0.068376 & 0 & 0.079176 \\
\hline Leucothoe racemosa & 0.026367 & 0.02473 & 514.2857 & 0.076923 & $\mathbf{0}$ & 0.050827 \\
\hline$* * *$ & 0.023001 & 0.021573 & 285.7143 & 0.042735 & $\mathbf{0}$ & 0.032154 \\
\hline Nyssa sylvatica & 0.024964 & 0.023415 & 114.2857 & 0.017094 & 1 & 0.020254 \\
\hline *** & 0.014025 & 0.013154 & 171.4286 & 0.025641 & 1 & 0.019398 \\
\hline Toxicodendron radicans & 0.008134 & 0.00763 & 114.2857 & 0.017094 & 0 & 0.012362 \\
\hline Platanus occidentalis & 0.013744 & 0.012891 & 57.14286 & 0.008547 & $\mathbf{0}$ & 0.010719 \\
\hline Cephalanthus occidentalis & 0.010098 & 0.009471 & 57.14286 & 0.008547 & $\mathbf{0}$ & 0.009009 \\
\hline Quercus muhlenbergii & 0.004488 & 0.004209 & 57.14286 & 0.008547 & $\mathbf{0}$ & 0.006378 \\
\hline $\begin{array}{l}\text { site } 5 \mathbf{a} \\
\text { overstory }\end{array}$ & $\begin{array}{l}\text { Meter^2/ } \\
\text { Hectare }\end{array}$ & $\begin{array}{l}\text { Relative } \\
\text { Dom }\end{array}$ & $\begin{array}{l}\text { Density/ } \\
\text { Hectare }\end{array}$ & $\begin{array}{l}\text { Relative } \\
\text { Density }\end{array}$ & $\begin{array}{l}\text { Percent } \\
\text { Sprouts }\end{array}$ & $\begin{array}{l}\text { Importanc } \\
\text { Values }\end{array}$ \\
\hline Total & 1.194927 & 1 & 685.7143 & 1 & 0.33 & 1 \\
\hline Ulmus americana & 0.587927 & 0.492019 & 171.4286 & 0.25 & 1 & 0.371009 \\
\hline Acer rubrum & 0.250486 & 0.209624 & 171.4286 & 0.25 & $\mathbf{0}$ & 0.229812 \\
\hline **** & 0.12931 & 0.108216 & 171.4286 & 0.25 & 0 & 0.179108 \\
\hline Salix nigra & 0.115005 & 0.096244 & 114.2857 & 0.166667 & $\mathbf{0}$ & 0.131455 \\
\hline Taxodium distichum & 0.1122 & 0.093897 & 57.14286 & 0.083333 & 1 & 0.088615 \\
\hline
\end{tabular}


Site \# -5b

Location (Coordinates) - 36 $39^{\prime} 37^{\prime \prime} \mathrm{W} \quad 7^{\circ} 26^{\prime} 51^{\prime \prime} \mathrm{N}$

Owner and Contact - Union Camp exp. site

Nearest Stream - Meherrin River

River Basin - Meherrin River

NWI Classification -

Approximate Size of Site - 10

Age of Site - 5

Site 5b

herbaceous

Total

Polygonum punctatum

Juncus effusus

Scirpus cyperinus

Boehmeria cylindrica

***

***

***

Campsis radicans

***

Leucothoe racemosa

Toxicodendron radicans

***

***

Viola spp

Arundinaria gigantea

Carex lupulina

***

Acer rubrum

Sagittaria latifolia

***

Galium obtusum

***

Ludwigia glandulosa $\begin{array}{lllll}\text { Mean } & \text { Relative } & \text { Density/ } & \text { Relative } & \text { Importanc } \\ \text { Cover } & \text { Dom . } & 0.5 \mathrm{~m}^{\wedge} 2 & \text { Density } & \text { Values }\end{array}$

$\begin{array}{lllll}57.02 & 1 & 80.8 & 1 & 1\end{array}$

$20.04 \quad 0.351456$

$\begin{array}{ll}3 & 0.052613\end{array}$

$\begin{array}{ll}7.5 & 0.131533\end{array}$

$\begin{array}{ll}6 & 0.105226\end{array}$

$\begin{array}{lll}3.5 & 0.061382\end{array}$

$\begin{array}{ll}3 & 0.052613\end{array}$

$\begin{array}{ll}3.5 & 0.061382\end{array}$

$\begin{array}{ll}3 & 0.052613\end{array}$

$\begin{array}{ll}0.04 & 0.000702\end{array}$

$\begin{array}{ll}3 & 0.052613\end{array}$

10.017538

$0.5 \quad 0.008769$

$\begin{array}{ll}0.8 & 0.01403\end{array}$

$\begin{array}{ll}0.5 & 0.008769\end{array}$

$0.02 \quad 0.000351$

$0.02 \quad 0.000351$

0.020 .000351

$\begin{array}{ll}0.52 & 0.00912\end{array}$

$\begin{array}{ll}0.5 & 0.008769\end{array}$

$\begin{array}{ll}0.5 & 0.008769\end{array}$

$0.02 \quad 0.000351$

$\begin{array}{ll}0.02 & 0.000351\end{array}$

$\begin{array}{ll}0.02 & 0.000351\end{array}$

$\begin{array}{rrr}.33 .6 & 0.415842 & 0.383649 \\ 16 & 0.19802 & 0.125316 \\ 5.6 & 0.069307 & 0.10042 \\ 2.6 & 0.032178 & 0.068702 \\ 1.8 & 0.022277 & 0.04183 \\ 2.4 & 0.029703 & 0.041158 \\ 1.4 & 0.017327 & 0.039354 \\ 1.6 & 0.019802 & 0.036208 \\ 5.6 & 0.069307 & 0.035004 \\ 0.2 & 0.002475 & 0.027544 \\ 2.6 & 0.032178 & 0.024858 \\ 2 & 0.024752 & 0.016761 \\ 0.2 & 0.002475 & 0.008253 \\ 0.4 & 0.00495 & 0.00686 \\ 1 & 0.012376 & 0.006363 \\ 1 & 0.012376 & 0.006363 \\ 1 & 0.012376 & 0.006363 \\ 0.2 & 0.002475 & 0.005797 \\ 0.2 & 0.002475 & 0.005622 \\ 0.2 & 0.002475 & 0.005622 \\ 0.4 & 0.00495 & 0.002651 \\ 0.4 & 0.00495 & 0.002651 \\ 0.4 & 0.00495 & 0.002651\end{array}$

*** - unidentified species 


\begin{tabular}{|c|c|c|c|c|c|c|}
\hline $\begin{array}{l}\text { Site 5b } \\
\text { understory }\end{array}$ & $\begin{array}{l}\text { Meter^2/ } \\
\text { Hectare }\end{array}$ & $\begin{array}{l}\text { Relative } \\
\text { Dom }\end{array}$ & $\begin{array}{l}\text { Density/ } \\
\text { Hectare }\end{array}$ & $\begin{array}{l}\text { Relative } \\
\text { Density }\end{array}$ & $\begin{array}{l}\text { Percent } \\
\text { Sprouts }\end{array}$ & $\begin{array}{l}\text { Importanc } \\
\text { Values }\end{array}$ \\
\hline Total & 2.399391 & 1 & 10880 & 1 & 0.279412 & 1 \\
\hline Acer rubrum & 0.944049 & 0.393453 & 3440 & 0.316176 & 0.55814 & 0.354815 \\
\hline Fraxinus spp & 0.601222 & 0.250573 & 1520 & 0.139706 & $\mathbf{0}$ & 0.195139 \\
\hline Leucothoe racemosa & 0.214021 & 0.089198 & 3040 & 0.279412 & $\mathbf{0}$ & 0.184305 \\
\hline Populus heterophylla & 0.342041 & 0.142553 & 1600 & 0.147059 & 0.65 & 0.144806 \\
\hline$* * *$ & 0.154723 & 0.064484 & 480 & 0.044118 & o & 0.054301 \\
\hline Cephalanthus occidentalis & 0.076576 & 0.031915 & 400 & 0.036765 & $\mathbf{0}$ & 0.03434 \\
\hline$* * *$ & 0.023955 & 0.009984 & 240 & 0.022059 & $\mathbf{0}$ & 0.016021 \\
\hline Salix nigra & 0.03927 & 0.016367 & 80 & 0.007353 & 1 & 0.01186 \\
\hline Alnus rugosa & 0.003534 & 0.001473 & 80 & 0.007353 & $\mathbf{0}$ & 0.004413 \\
\hline $\begin{array}{l}\text { Site } 5 b \\
\text { overstory }\end{array}$ & $\begin{array}{l}\text { Meter^2/ } \\
\text { Hectare }\end{array}$ & $\begin{array}{l}\text { Relative } \\
\text { Dom }\end{array}$ & $\begin{array}{l}\text { Density/ } \\
\text { Hectare }\end{array}$ & $\begin{array}{l}\text { Relative } \\
\text { Density }\end{array}$ & $\begin{array}{l}\text { Percent } \\
\text { Sprouts }\end{array}$ & $\begin{array}{l}\text { Importanc } \\
\text { Values }\end{array}$ \\
\hline Total & 2.403711 & 1 & 2080 & 1 & 0.461538 & 1 \\
\hline Acer rubrum & 1.533097 & 0.637804 & 960 & 0.461538 & 0.833333 & 0.549671 \\
\hline Fraxinus spp & 0.550957 & 0.229211 & 720 & 0.346154 & 0 & 0.287682 \\
\hline Populus heterophylla & 0.193601 & 0.080542 & 160 & 0.076923 & 1 & 0.078733 \\
\hline Carpinus caroliniana & 0.047517 & 0.019768 & 80 & 0.038462 & $\mathbf{0}$ & 0.029115 \\
\hline$* * *$ & 0.03927 & 0.016337 & 80 & 0.038462 & $\mathbf{0}$ & 0.027399 \\
\hline Salix nigra & 0.03927 & 0.016337 & 80 & 0.038462 & $\mathbf{0}$ & 0.027399 \\
\hline
\end{tabular}

*** - unidentified species 
Site \# 7a

Location (Coordinates) -

Owner and Contact - Pope

Nearest Stream - Blackwater River

River Basin - Blackwater River

NWI Classification - PF01E

Approximate Size of Site - 8 acres

Age of Site -7 years

\begin{tabular}{|c|c|c|c|c|c|}
\hline $\begin{array}{l}\text { Site 7a } \\
\text { herbaceous }\end{array}$ & $\begin{array}{l}\text { Mean } \\
\text { Cover }\end{array}$ & $\begin{array}{l}\text { Relative } \\
\text { Dom }\end{array}$ & $\begin{array}{l}\text { Density/ } \\
0.5 \mathrm{~m}^{\wedge} 2\end{array}$ & $\begin{array}{l}\text { Relative } \\
\text { Density }\end{array}$ & $\begin{array}{l}\text { Importanc } \\
\text { Values }\end{array}$ \\
\hline Total & 68.46667 & 1 & 178 & 1 & \\
\hline Polygonum punctatum & 33.33333 & 0.486855 & 92.16667 & 0.51779 & 0.502323 \\
\hline Ludwigia repens & 8.75 & 0.127799 & 45.16667 & 0.253745 & 0.190772 \\
\hline Scirpus cyperinus & 19.58333 & 0.286027 & 7.666667 & 0.043071 & 0.164549 \\
\hline Lemna spp & 0.416667 & 0.006086 & 18.66667 & 0.104869 & 0.055477 \\
\hline Echinodorus cordifolius & 2.5 & 0.036514 & 0.333333 & 0.001873 & 0.019193 \\
\hline *** & 0.016667 & 0.000243 & 3.333333 & 0.018727 & 0.009485 \\
\hline Limonium spp & 0.016667 & 0.000243 & 3.333333 & 0.018727 & 0.009485 \\
\hline Hydrocotyle umbellata & 0.433333 & 0.006329 & 2 & 0.011236 & 0.008783 \\
\hline *** & 0.416667 & 0.006086 & 1.333333 & 0.007491 & 0.006788 \\
\hline *** & 0.416667 & 0.006086 & 1.166667 & 0.006554 & 0.00632 \\
\hline Carex joorii & 0.416667 & 0.006086 & 0.5 & 0.002809 & 0.004447 \\
\hline Saururus cernuus & 0.433333 & 0.006329 & 0.333333 & 0.001873 & 0.004101 \\
\hline$* * *$ & 0.433333 & 0.006329 & 0.333333 & 0.001873 & 0.004101 \\
\hline Carex spp & 0.416667 & 0.006086 & 0.333333 & 0.001873 & 0.003979 \\
\hline$* * *$ & 0.416667 & 0.006086 & 0.166667 & 0.000936 & 0.003511 \\
\hline *** & 0.416667 & 0.006086 & $\mathbf{0}$ & 0 & 0.003043 \\
\hline *** & 0.016667 & 0.000243 & 0.5 & 0.002809 & 0.001526 \\
\hline *** & 0.016667 & 0.000243 & 0.5 & 0.002809 & 0.001526 \\
\hline *** & 0.016667 & 0.000243 & 0.166667 & 0.000936 & 0.00059 \\
\hline
\end{tabular}

*** - unidentified species 


\begin{tabular}{|c|c|c|c|c|c|c|}
\hline $\begin{array}{l}\text { Site 7a } \\
\text { understory }\end{array}$ & $\begin{array}{l}\text { Meter^2/ } \\
\text { Hectare }\end{array}$ & $\begin{array}{l}\text { Relative } \\
\text { Dom }\end{array}$ & $\begin{array}{l}\text { Density/ } \\
\text { Hectare }\end{array}$ & $\begin{array}{l}\text { Relative } \\
\text { Density }\end{array}$ & $\begin{array}{l}\text { Percent } \\
\text { Sprouts }\end{array}$ & $\begin{array}{l}\text { Importanc } \\
\text { Values }\end{array}$ \\
\hline Total & 2.272746 & 1 & 8266.667 & 1 & 0.427419 & 1 \\
\hline Taxodium distichum & 1.518764 & 0.668251 & 3933.333 & 0.475806 & 0.372881 & 0.572028 \\
\hline Nyssa aquatica & 0.294197 & 0.129446 & 2066.667 & 0.25 & 0.612903 & 0.189723 \\
\hline Salix nigra & 0.319395 & 0.140533 & 866.6667 & 0.104839 & 0.769231 & 0.122686 \\
\hline Acer rubrum & 0.044833 & 0.019726 & 400 & 0.048387 & 0.333333 & 0.034057 \\
\hline Cephalanthus occidentalis & 0.036979 & 0.016271 & 266.6667 & 0.032258 & $\mathbf{0}$ & 0.024264 \\
\hline Hypericum walteri & 0.005563 & 0.002448 & 333.3333 & 0.040323 & 0 & 0.021385 \\
\hline$* * *$ & 0.021271 & 0.009359 & 133.3333 & 0.016129 & 0 & 0.012744 \\
\hline Carpinus caroliniana & 0.014726 & 0.006479 & 133.3333 & 0.016129 & $\mathbf{0}$ & 0.011304 \\
\hline Populus heterophylla & 0.011781 & 0.005184 & 66.66667 & 0.008065 & 0 & 0.006624 \\
\hline Fraxinus spp & 0.005236 & 0.002304 & 66.66667 & 0.008065 & 0 & 0.005184 \\
\hline $\begin{array}{l}\text { Site } 7 \mathrm{~b} \\
\text { overstory }\end{array}$ & $\begin{array}{l}\text { Meter^2/ } \\
\text { Hectare }\end{array}$ & $\begin{array}{l}\text { Relative } \\
\text { Dom }\end{array}$ & $\begin{array}{l}\text { Density/ } \\
\text { Hectare }\end{array}$ & $\begin{array}{l}\text { Relative } \\
\text { Density }\end{array}$ & $\begin{array}{l}\text { Percent } \\
\text { Sprouts }\end{array}$ & $\begin{array}{l}\text { Importanc } \\
\text { Values }\end{array}$ \\
\hline Total & 1.094321 & 1 & 933.3333 & 1 & 0.642857 & 1 \\
\hline Salix nigra & 0.82565 & 0.754486 & 533.3333 & 0.571429 & 0.75 & 0.662957 \\
\hline Taxodium distichum & 0.19635 & 0.179426 & 266.6667 & 0.285714 & 0.75 & 0.23257 \\
\hline Populus heterophylla & 0.039597 & 0.036184 & 66.66667 & 0.071429 & $\mathbf{0}$ & 0.053806 \\
\hline Betula nigra & 0.032725 & 0.029904 & 66.66667 & 0.071429 & $\mathbf{0}$ & 0.050666 \\
\hline
\end{tabular}

*** - unidentified species 
Site \# -8a

Location (Coordinates) - 36042'45" 76052'45"

Owner and Contact -Clara B. Worrell

Nearest Stream - Beaverdam Swamp

River Basin - Blackwater River

NWI Classification - PF01A

Approximate Size of Site - 27 acres

Age of Site - 8

Site 8a

herbaceous

Total

Typha spp

Leersia oryzoides

Polygonum punctatum

Saururus cernuus

Proserpinaca palustris

Ludwigia palustris

Carex spp.

***

Hydrocotyle umbellata

Polygonum pensylvanicum

Phragmites australis

Galium obtusum

***

***

Boehmeria cylindrica

Hypericum spp

Pontedaria cordata

Carex spp

Acer rubrum

Nyssa sylvatica

Polygonum hydropiperoides

Juncus effusus

\begin{tabular}{|c|c|c|c|c|}
\hline $\begin{array}{l}\text { Mean } \\
\text { Cover }\end{array}$ & $\begin{array}{l}\text { Relative } \\
\text { Dom }\end{array}$ & $\begin{array}{l}\text { Density/ } \\
0.5 \mathrm{~m}^{\wedge} 2\end{array}$ & $\begin{array}{l}\text { Relative } \\
\text { Density }\end{array}$ & $\begin{array}{l}\text { Importanc } \\
\text { Values }\end{array}$ \\
\hline 30.2 & 1 & 38.42857 & 1 & \\
\hline 14.64286 & 0.484863 & 7.857143 & 0.204461 & 0.344662 \\
\hline 2.5 & 0.082781 & 6.428571 & 0.167286 & 0.125034 \\
\hline 1.085714 & 0.035951 & 8.142857 & 0.211896 & 0.123923 \\
\hline 5 & 0.165563 & 2.428571 & 0.063197 & 0.11438 \\
\hline 2.5 & 0.082781 & 3.285714 & 0.085502 & 0.084142 \\
\hline 0.014286 & 0.000473 & 2.142857 & 0.055762 & 0.028118 \\
\hline 7143 & 0.011826 & 1.285714 & 457 & 0.022642 \\
\hline 0.714286 & 0.023652 & 0.714286 & 0.0 & 0.02112 \\
\hline 0.014286 & 0.000473 & 1.571429 & 0.040892 & 0.020683 \\
\hline 1.1 & 0.036424 & 0.142857 & 0.003717 & 0.020071 \\
\hline 0.714286 & 0.023652 & 0.571429 & 0.01487 & 0.019261 \\
\hline 0.028571 & 0.000946 & 1.285714 & 0.033457 & 0.017202 \\
\hline 0.357143 & 0.011826 & 0.714286 & 0.018587 & 0.015207 \\
\hline 0.028571 & 0.000946 & 0.714286 & 0.018587 & 0.009767 \\
\hline 0.357143 & 0.011826 & 0.285714 & 0.007435 & 0.00963 \\
\hline 0.357143 & 0.011826 & 0.142857 & 0.003717 & 0.007772 \\
\hline 0.357143 & 0.011826 & 0.142857 & 0.003717 & 0.007772 \\
\hline 0.014286 & 0.000473 & 0.142857 & 0.003717 & 0.002095 \\
\hline 0.014286 & 0.000473 & 0.142857 & 0.003717 & 0.002095 \\
\hline 0.014286 & 0.000473 & 0.142857 & 0.003717 & 0.002095 \\
\hline 0.014286 & 0.000473 & 0.142857 & 0.003717 & 0.002095 \\
\hline 0.014286 & 0.000473 & 0 & 0 & 0.000237 \\
\hline
\end{tabular}

*** - unidentified species 
Site 8a

understory

Total

Salix nigra

Acer rubrum

Fraxinus spp

Ilex verticillata

Rhododendron spp

Taxodium distichum

Nyssa sylvatica

Site 8a

overstory

Total

Salix nigra

Acer rubrum

Fraxinus spp
Meter^2/ Relative Density/ Relative Percent Importanc Hectare Dom Hectare Density Sprouts Values

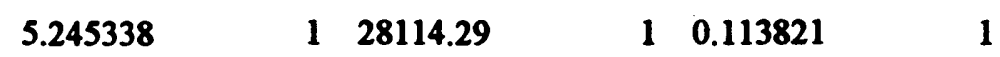

$\begin{array}{rrrrrrr}4.398791 & 0.83861 & 24742.86 & 0.880081 & 0.12933 & 0.859345 \\ 0.461421 & 0.087968 & 1257.143 & 0.044715 & 0 & 0.066342 \\ 0.189057 & 0.036043 & 914.2857 & 0.03252 & 0 & 0.034282 \\ 0.082186 & 0.015668 & 400 & 0.014228 & 0 & 0.014948 \\ 0.063393 & 0.012086 & 400 & 0.014228 & 0 & 0.013157 \\ 0.04516 & 0.00861 & 228.5714 & 0.00813 & 0 & 0.00837 \\ 0.005329 & 0.001016 & 171.4286 & 0.006098 & 0 & 0.003557\end{array}$

Meter^2/ Relative Density/ Relative Percent Importanc Hectare Dom Hectare Density Sprouts Values

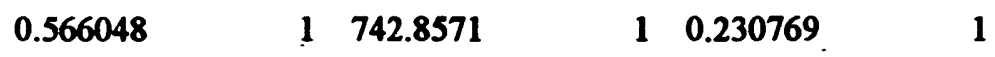

$\begin{array}{lllllll}0.240107 & 0.424182 & 400 & 0.538462 & 0.428571 & 0.481322\end{array}$

$\begin{array}{lllllll}0.285548 & 0.50446 & 285.7143 & 0.384615 & 0 & 0.444538\end{array}$

$\begin{array}{llllll}0.040392 & 0.071358 & 57.14286 & 0.076923 & 0 & 0.07414\end{array}$

*** - unidentified species 
Site \# -8b

Location (Coordinates) - 36042'30" 77022'45"

Owner and Contact -Union Camp

Nearest Stream- Browns Branch

River Basin - Nottoway River

NWI Classification - PF01A

Approximate Size of Site - 24 acres

Age of Site - 8

\begin{tabular}{|c|c|c|c|c|c|}
\hline $\begin{array}{l}\text { Site } 8 b \\
\text { herbaceous }\end{array}$ & $\begin{array}{l}\text { Mean } \\
\text { Cover }\end{array}$ & $\begin{array}{l}\text { Relative } \\
\text { Dom }\end{array}$ & $\begin{array}{l}\text { Density/ } \\
0.5 \mathrm{~m}^{\wedge} 2\end{array}$ & $\begin{array}{l}\text { Relative } \\
\text { Density }\end{array}$ & $\begin{array}{l}\text { Importanc } \\
\text { Values }\end{array}$ \\
\hline Total & 86.45 & 1 & 88.25 & 1 & 1 \\
\hline Murdania keisak & 15.625 & 0.18074 & 16.25 & 0.184136 & 0.182438 \\
\hline$* * *$ & 13.125 & 0.151822 & 13.5 & 0.152975 & 0.152398 \\
\hline Polygonum hydropiperoides & 7.5 & 0.086755 & 12 & 0.135977 & 0.111366 \\
\hline Sparganium americanum & 4.375 & 0.050607 & 12.75 & 0.144476 & 0.097542 \\
\hline Saururus cernuus & 9.375 & 0.108444 & 3.75 & 0.042493 & 0.075469 \\
\hline Boehmeria cylindrica & 3.75 & 0.043378 & 3.75 & 0.042493 & 0.042935 \\
\hline Leersia oryzoides & 3.75 & 0.043378 & 3.75 & 0.042493 & 0.042935 \\
\hline$* * *$ & 0.025 & 0.000289 & 6.75 & 0.076487 & 0.038388 \\
\hline Fraxinus spp & 3.75 & 0.043378 & 2.75 & 0.031161 & 0.03727 \\
\hline Commelina virginica & 4.375 & 0.050607 & 0.75 & 0.008499 & 0.029553 \\
\hline *** & 3.75 & 0.043378 & 1.25 & 0.014164 & 0.028771 \\
\hline Typha spp & 3.75 & 0.043378 & 1 & 0.011331 & 0.027355 \\
\hline Sagittaria latifolia & 3.75 & 0.043378 & 0.75 & 0.008499 & 0.025938 \\
\hline$* * *$ & 3.75 & 0.043378 & 0.25 & 0.002833 & 0.023105 \\
\hline Acer rubrum & 1.25 & 0.014459 & 2.5 & 0.028329 & 0.021394 \\
\hline Campsis radicans & 0.625 & 0.00723 & 2 & 0.022663 & 0.014946 \\
\hline Pontedaria cordata & 1.25 & 0.014459 & 0.5 & 0.005666 & 0.010062 \\
\hline$* * *$ & 0.625 & 0.00723 & 0.75 & 0.008499 & 0.007864 \\
\hline Hydrocotyle umbellata & 0.65 & 0.007519 & 0.5 & 0.005666 & 0.006592 \\
\hline **** & 0.625 & 0.00723 & 0.5 & 0.005666 & 0.006448 \\
\hline Leersia oryzoides & 0.025 & 0.000289 & 1 & 0.011331 & $\begin{array}{r}0.00581 \\
0.005031\end{array}$ \\
\hline *** & 0.625 & 0.00723 & 0.25 & 0.002833 & 0.005031 \\
\hline $\begin{array}{l}\text { Rhyncosphora inundata } \\
* * *\end{array}$ & $\begin{array}{l}0.025 \\
0.025\end{array}$ & 0.000289 & 0.5 & 0.005666 & $\begin{array}{l}0.002977 \\
0.001561\end{array}$ \\
\hline Ludwigia palustris & $\begin{array}{l}0.023 \\
0.025\end{array}$ & $\begin{array}{l}0.000289 \\
0.000289\end{array}$ & $\begin{array}{l}0.25 \\
0.25\end{array}$ & $\begin{array}{l}0.002833 \\
0.002833\end{array}$ & $0.00156 ?$ \\
\hline *** & 0.025 & 0.000289 & $\mathbf{0}$ & $\mathbf{0}$ & 0.000145 \\
\hline *** & 0.025 & 0.000289 & $\mathbf{0}$ & 0 & 0.000145 \\
\hline
\end{tabular}

*** - unidentified species 


$\begin{array}{lllrrrrr}\begin{array}{l}\text { site 8b } \\ \text { understory }\end{array} & \begin{array}{l}\text { Meter } 2 / \\ \text { Hectare }\end{array} & \begin{array}{l}\text { Relative } \\ \text { Dom }\end{array} & \begin{array}{l}\text { Density/ } \\ \text { Hectare }\end{array} & \begin{array}{l}\text { Relative } \\ \text { Density }\end{array} & \begin{array}{l}\text { Percent } \\ \text { Sprouts }\end{array} & \begin{array}{l}\text { Importanc } \\ \text { Values }\end{array} \\ \text { Total } & 3.716406 & 1 & 30500 & 1 & 0.170492 & 1 \\ & & & & & & & \\ \text { Acer rubrum } & 2.273728 & 0.611808 & 16500 & 0.540984 & 0.909091 & 0.576396 \\ \text { Fraxinus spp } & 1.053415 & 0.28345 & 9300 & 0.304918 & 0.946237 & 0.294184 \\ \text { Nyssa aquatica } & 0.091303 & 0.024567 & 1300 & 0.042623 & 0.692308 & 0.033595 \\ \text { Gaultheria procumbens } & 0.107992 & 0.029058 & 500 & 0.016393 & 0.8 & 0.022726 \\ \text { Carpinus caroliniana } & 0.043197 & 0.011623 & 800 & 0.02623 & 0.25 & 0.018926 \\ \text { Cephalanthus occidental } & 0.057432 & 0.015454 & 400 & 0.013115 & 0 & 0.014284 \\ \text { Cornus stricta } & 0.054978 & 0.014793 & 400 & 0.013115 & 1 & 0.013954 \\ \text { Quercus lyrata } & 0.015217 & 0.004095 & 600 & 0.019672 & 0.5 & 0.011883 \\ \text { Liquidambar styraciflua } & 0.002945 & 0.000792 & 300 & 0.009836 & 0.666667 & 0.005314 \\ \text { Rhus glabra } & 0.012272 & 0.003302 & 200 & 0.006557 & 0 & 0.00493 \\ \text { Itea virginica } & 0.001963 & 0.000528 & 100 & 0.003279 & 0 & 0.001904 \\ \text { Taxodium distichum } & 0.001963 & 0.000528 & 100 & 0.003279 & 0 & 0.001904\end{array}$

\begin{tabular}{|c|c|c|c|c|c|c|}
\hline $\begin{array}{l}\text { Site } 8 b \\
\text { overstory }\end{array}$ & $\begin{array}{l}\text { Meter^2/ } \\
\text { Hectare }\end{array}$ & $\begin{array}{l}\text { Relative } \\
\text { Dom }\end{array}$ & $\begin{array}{l}\text { Density/ } \\
\text { Hectare }\end{array}$ & $\begin{array}{l}\text { Relative } \\
\text { Density }\end{array}$ & $\begin{array}{l}\text { Percent } \\
\text { Sprouts }\end{array}$ & $\begin{array}{l}\text { Importanc } \\
\text { Values }\end{array}$ \\
\hline Total & 9.531298 & 1 & 2600 & 1 & 0.730769 & \\
\hline Acer rubrum & 6.617961 & 0.69434 & 1400 & 0.538462 & 0.928571 & 0.616401 \\
\hline Fraxinus spp & 2.307598 & 0.242107 & 500 & 0.192308 & 0.6 & 0.217208 \\
\hline Nyssa aquatica & 0.255745 & 0.026832 & 300 & 0.115385 & 0 & 0.071108 \\
\hline Gaultheria procumbens & 0.208621 & 0.021888 & 200 & 0.076923 & 1 & 0.049406 \\
\hline Carpinus caroliniana & 0.070686 & 0.007416 & 100 & 0.038462 & 1 & 0.022939 \\
\hline Taxodium distichum & 0.070686 & 0.007416 & 100 & 0.038462 & $\mathbf{0}$ & 0.022939 \\
\hline
\end{tabular}

*** - unidentified species 
Site \# -9a

Location (Coordinates) - 36033'45" 76049'50"

Owner and Contact -Union Camp

Nearest Stream - Somerton Creek

River Basin - Chowan River

NWI Classification -PF01E

Approximate Size of Site -17 acres

Age of Site - 9

Site 9a

herbaceous

Total

Hydrocotyle umbellata

Saururus cernuus

Polygonum punctatum

***

Mikania scandens

Leersia oryzoides

Lycopus virginicus

***

***

***

Boehmeria cylindrica

***

Carex lurida

Galium obtusum

Carex spp

Bidens laevis

***

****

Ludwigia palustris

***

Nyssa aquatica

Acer rubrum

Sparganium americanum $\begin{array}{lllll}\text { Mean } & \text { Relative } & \text { Density/ } & \text { Relative } & \text { Importanc } \\ \text { Cover } & \text { Dom } & 0.5 \mathrm{~m}^{\wedge} 2 & \text { Density } & \text { Values }\end{array}$

63.18

1

46.8

1

1

$\begin{array}{rr}7 & 0.110795 \\ 18 & 0.2849 \\ 9.5 & 0.150364 \\ 7.5 & 0.118708 \\ 6 & 0.094967\end{array}$

$\begin{array}{rr}12.8 & 0.273504\end{array}$

$\begin{array}{llll}3.8 & 0.081197 & 0.183048\end{array}$

$\begin{array}{lll}4.8 & 0.102564 & 0.126464\end{array}$

$\begin{array}{llll}3 & 0.064103 & 0.091406\end{array}$

$\begin{array}{lll}1 & 0.021368 & 0.058167\end{array}$

$\begin{array}{llll}3 & 0.064103 & 0.055951\end{array}$

$\begin{array}{ll}3.02 & 0.0478\end{array}$

$\begin{array}{ll}3.5 & 0.055397\end{array}$

$\begin{array}{ll}0.5 & 0.007914\end{array}$

$\begin{array}{ll}3.02 & 0.0478\end{array}$

$\begin{array}{ll}0.5 & 0.007914\end{array}$

$\begin{array}{ll}0.5 & 0.007914\end{array}$

$\begin{array}{ll}0.5 & 0.007914\end{array}$

$\begin{array}{ll}1 & 0.015828\end{array}$

$\begin{array}{ll}0.52 & 0.00823\end{array}$

$\begin{array}{ll}0.5 & 0.007914\end{array}$

$\begin{array}{ll}0.5 & 0.007914\end{array}$

$0.02 \quad 0.000317$

$0.04 \quad 0.000633$

$\begin{array}{ll}0.02 & 0.000317\end{array}$

$\begin{array}{ll}0.5 & 0.007914\end{array}$

$\begin{array}{ll}0.5 & 0.007914\end{array}$

$\begin{array}{ll}0.02 & 0.000317\end{array}$

$\begin{array}{ll}0.02 & 0.000317\end{array}$ $\begin{array}{llll}2.2 & 0.047009 & 0.051203\end{array}$

$\begin{array}{llll}3.6 & 0.076923 & 0.042418\end{array}$

$\begin{array}{llll}1.6 & 0.034188 & 0.040994\end{array}$

$\begin{array}{lll}1.8 & 0.038462 & 0.023188\end{array}$

$\begin{array}{llll}1.2 & 0.025641 & 0.016777\end{array}$

$\begin{array}{llll}1.2 & 0.025641 & 0.016777\end{array}$

$\begin{array}{llll}0.8 & 0.017094 & 0.016461\end{array}$

$\begin{array}{lll}1 & 0.021368 & 0.014799\end{array}$

$\begin{array}{lll}1 & 0.021368 & 0.014641\end{array}$

$\begin{array}{lll}0.8 & 0.017094 & 0.01250\end{array}$

$\begin{array}{llll}0.8 & 0.017094 & 0.008705\end{array}$

$\begin{array}{llll}0.6 & 0.012821 & 0.006727\end{array}$

$\begin{array}{llll}0.6 & 0.012821 & 0.006569\end{array}$

$\begin{array}{llll}0.2 & 0.004274 & 0.006094\end{array}$

$\begin{array}{llll}0.2 & 0.004274 & 0.006094\end{array}$

$\begin{array}{llll}0.4 & 0.008547 & 0.004432\end{array}$

$\begin{array}{llll}0.4 & 0.008547 & 0.004432\end{array}$

*** - unidentified species 


\begin{tabular}{|c|c|c|c|c|c|c|}
\hline $\begin{array}{l}\text { Site 9a } \\
\text { understory }\end{array}$ & $\begin{array}{l}\text { Meter^2/ } \\
\text { Hectare }\end{array}$ & $\begin{array}{l}\text { Relative } \\
\text { Dom }\end{array}$ & $\begin{array}{l}\text { Density/ } \\
\text { Hectare }\end{array}$ & $\begin{array}{l}\text { Relative } \\
\text { Density }\end{array}$ & $\begin{array}{l}\text { Percent } \\
\text { Sprouts }\end{array}$ & $\begin{array}{l}\text { Importanc } \\
\text { Values }\end{array}$ \\
\hline Total & 2.059707 & 1 & 17520 & 1 & 0.821918 & 1 \\
\hline Salix nigra & 0.589834 & 0.286368 & 5200 & 0.296804 & 0.753846 & 0.291586 \\
\hline Acer rubrum & 0.6562 & 0.318589 & 3360 & 0.191781 & 0.928571 & 0.255185 \\
\hline Nyssa aquatica & 0.349109 & 0.169495 & 2960 & 0.16895 & 0.72973 & 0.169222 \\
\hline Taxodium distichum & 0.281173 & 0.136511 & 2800 & 0.159817 & 0.914286 & 0.148164 \\
\hline Liquidambar styraciflua & 0.132732 & 0.064442 & 2400 & 0.136986 & 1 & 0.100714 \\
\hline Rubus spp & 0.040841 & 0.019828 & 480 & 0.027397 & 0 & 0.023613 \\
\hline Populus heterophylla & 0.003534 & 0.001716 & 240 & 0.013699 & 1 & 0.007707 \\
\hline **** & 0.006283 & 0.003051 & 80 & 0.004566 & $\mathbf{0}$ & 0.003808 \\
\hline $\begin{array}{l}\text { Site 9a } \\
\text { overstory }\end{array}$ & $\begin{array}{l}\text { Meter`2/ } \\
\text { Hectare }\end{array}$ & $\begin{array}{l}\text { Relative } \\
\text { Dom }\end{array}$ & $\begin{array}{l}\text { Density/ } \\
\text { Hectare }\end{array}$ & $\begin{array}{l}\text { Relative } \\
\text { Density }\end{array}$ & $\begin{array}{l}\text { Percent } \\
\text { Sprouts }\end{array}$ & $\begin{array}{l}\text { Importanc } \\
\text { Values }\end{array}$ \\
\hline Total & 10.45522 & 1 & 2800 & 1 & 0.828571 & 1 \\
\hline Acer rubrum & 3.884972 & 0.371582 & 1760 & 0.628571 & 0.863636 & 0.500077 \\
\hline Taxodium distichum & 3.358755 & 0.321252 & 240 & 0.085714 & 1 & 0.203483 \\
\hline Nyssa aquatica & 1.594751 & 0.152532 & 480 & 0.171429 & 0.666667 & 0.16198 \\
\hline Salix nigra & 1.616742 & 0.154635 & 320 & 0.114286 & 0.75 & 0.13446 \\
\hline
\end{tabular}

*** - unidentified species 
Site \# -10a

Location (Coordinates) $-36033^{\prime} 45^{\prime \prime} 76050^{\prime} 00^{\prime \prime}$

Owner and Contact -Union Camp

Nearest Stream -Somerton Creek

River Basin - Chowan River

NWI Classification -PF01E

Approximate Size of Site -10 acres

Age of Site - 10

Site 10a

herbaceous

Total

Carex lupulina

Boehmeria cylindrica

Saururus cernuus

Polygonum punctatum

Lycopus virginicus

Ludwigia palustris

Carex lobelia

****

Campsis radicans

***

Hypericum spp

Typha angustifolia

Sagittaria latifolia

***

***

Bidens laevis

Impatiens capensis

Taxodium distichum

Toxicodendron radicans

Hydrocotyle umbellata

Mikania scandens
Mean

Cover

60.18

Relative

Dom

Density/ $0.5 \mathrm{~m}^{\wedge} 2$
Relative Importanc

Density Values

$\begin{array}{rrrrr}60.18 & 1 & 54.2 & 1 & 1 \\ & & & & \\ 15.5 & 0.257561 & 18 & 0.332103 & 0.294832 \\ 7.5 & 0.124626 & 8.2 & 0.151292 & 0.137959 \\ 10.5 & 0.174477 & 2.6 & 0.04797 & 0.111224 \\ 6.5 & 0.108009 & 4 & 0.073801 & 0.090905 \\ 6 & 0.099701 & 3 & 0.055351 & 0.077526 \\ 0.52 & 0.008641 & 7.8 & 0.143911 & 0.076276 \\ 3.5 & 0.058159 & 2.4 & 0.04428 & 0.05122 \\ 3.02 & 0.050183 & 1.6 & 0.02952 & 0.039852 \\ 3 & 0.04985 & 0.8 & 0.01476 & 0.032305 \\ 0.5 & 0.008308 & 1 & 0.01845 & 0.013379 \\ 0.52 & 0.008641 & 0.8 & 0.01476 & 0.0117 \\ 1 & 0.016617 & 0.2 & 0.00369 & 0.010153 \\ 0.5 & 0.008308 & 0.6 & 0.01107 & 0.009689 \\ 0.5 & 0.008308 & 0.4 & 0.00738 & 0.007844 \\ 0.02 & 0.000332 & 0.8 & 0.01476 & 0.007546 \\ 0.5 & 0.008308 & 0.2 & 0.00369 & 0.005999 \\ 0.5 & 0.008308 & 0.2 & 0.00369 & 0.005999 \\ 0.04 & 0.000665 & 0.6 & 0.01107 & 0.005867 \\ 0.02 & 0.000332 & 0.6 & 0.01107 & 0.005701 \\ 0.02 & 0.000332 & 0.4 & 0.00738 & 0.003856 \\ 0.02 & 0.000332 & 0 & 0 & 0.000166\end{array}$

*** - unidentified species 
Site 10a

understory

Total

Nyssa aquatica

Fraxinus spp

Liquidambar styraciflua

Taxodium distichum

Alnus rugosa

Carpinus caroliniana

Betula nigra

Salix nigra

Acer rubrum

Cephalanthus occidentalis

Ilex opaca

Itea virginica
Meter^2/ Relative Density/ Relative Percent Importanc

Hectare Dom Hectare Density Sprouts Values

$\begin{array}{llllll}0.9574 & 1 & 10160 & 1 & 0.787402 & 1\end{array}$

$\begin{array}{lllllll}0.3777777 & 0.394586 & 2480 & 0.244094 & 0.83871 & 0.31934\end{array}$

$\begin{array}{llllll}0.142942 & 0.149303 & 2320 & 0.228346 & 1 & 0.188825\end{array}$

$\begin{array}{llllll}0.121737 & 0.127153 & 1520 & 0.149606 & 1 & 0.13838\end{array}$

$\begin{array}{llllll}0.100924 & 0.105414 & 560 & 0.055118 & 0 & 0.080266\end{array}$

$\begin{array}{llllll}0.063225 & 0.066038 & 960 & 0.094488 & 1 & 0.080263\end{array}$

$\begin{array}{lllllll}0.067544 & 0.07055 & 480 & 0.047244 & 0.166667 & 0.058897\end{array}$

$\begin{array}{lllllll}0.020028 & 0.020919 & 800 & 0.07874 & 0.8 & 0.049829\end{array}$

$\begin{array}{llllll}0.017671 & 0.018458 & 320 & 0.031496 & 0.75 & 0.024977\end{array}$

$\begin{array}{lllllll}0.016493 & 0.017227 & 320 & 0.031496 & 0.5 & 0.024362\end{array}$

$\begin{array}{llllll}0.013352 & 0.013946 & 240 & 0.023622 & 0 & 0.018784\end{array}$

$\begin{array}{llllll}0.014137 & 0.014766 & 80 & 0.007874 & 0 & 0.01132\end{array}$

$\begin{array}{llllll}0.001571 & 0.001641 & 80 & 0.007874 & 0 & 0.004757\end{array}$
Site 10a

overstory

Total

Liquidambar styraciflua

Taxodium distichum

Nyssa aquatica

Alnus rugosa

Betula nigra

*** $\begin{array}{llllll}\text { Meter 2/ } & \text { Relative } & \text { Density/ } & \text { Relative } & \text { Percent } & \text { Importanc } \\ \text { Hectare } & \text { Dom } & \text { Hectare } & \text { Density } & \text { Sprouts } & \text { Values }\end{array}$

\footnotetext{
*** - unidentified species
}

$\begin{array}{rrrrrr}0.943 & 1 & 3040 & 1 & 0.868421 & 1 \\ 13.5609 & 0.664707 & 1040 & 0.342105 & 1 & 0.503406 \\ 4.510542 & 0.221091 & 640 & 0.210526 & 0.875 & 0.215808 \\ 0.860404 & 0.042174 & 720 & 0.236842 & 0.777778 & 0.139508 \\ 0.479093 & 0.023483 & 480 & 0.157895 & 1 & 0.090689 \\ 0.94287 & 0.046216 & 80 & 0.026316 & 0 & 0.036266 \\ 0.047517 & 0.002329 & 80 & 0.026316 & 0 & 0.014322\end{array}$


Site \# - 14a

Location (Coordinates) $-36051^{\prime} 00^{\prime \prime} 76059^{\prime} 15^{\prime \prime}$

Owner and Contact - Union Camp

Nearest Stream - Round Hill Swamp

River Basin - Blackwater River

NWI Classification - PF01E

Approximate Size of Site - 27 acres

Age of Site - 14

Site 14a

herbaceous

Total

Itea virginica

Clethra alnifolia

Woodwardia aquatica

Dulichium spp

Lemna spp

Lycopus virginicus

***

***

Proserpinaca palustris

***

Ilex opaca

Saururus cernuus

Carex spp.

$\begin{array}{lllll}\text { Mean } & \text { Relative } & \text { Density/ } & \text { Relative } & \text { Importanc } \\ \text { Cover } & \text { Dom } & 0.5 \mathrm{~m}^{\wedge} 2 & \text { Density } & \text { Values }\end{array}$

12.74

1

$\begin{array}{ll}3.5 & 0.274725\end{array}$

$\begin{array}{ll}3 & 0.235479\end{array}$

$\begin{array}{ll}3 & 0.235479\end{array}$

0.50 .039246

$\begin{array}{ll}0.02 & 0.00157\end{array}$

0.50 .039246

0.50 .039246

0.10 .007849

$\begin{array}{ll}0.5 & 0.039246\end{array}$

$0.5 \quad 0.039246$

0.50 .039246

0.10 .007849

$\begin{array}{ll}0.02 & 0.00157\end{array}$

$\begin{array}{rrr}7.8 & 1 & 1 \\ & 0 & 0 \\ 0.6 & 0.076923 & 0.175824 \\ 0.8 & 0.102564 & 0.169021 \\ 0.6 & 0.076923 & 0.156201 \\ 1.4 & 0.179487 & 0.109367 \\ 1.6 & 0.205128 & 0.103349 \\ 0.8 & 0.102564 & 0.070905 \\ 0.4 & 0.051282 & 0.045264 \\ 0.6 & 0.076923 & 0.042386 \\ 0.2 & 0.025641 & 0.032444 \\ 0.2 & 0.025641 & 0.032444 \\ 0.2 & 0.025641 & 0.032444 \\ 0.4 & 0.051282 & 0.029566 \\ 0 & 0 & 0.000785\end{array}$

*** - unidentified species 
Site 14a

understory

Total

Magnolia virginiana

Acer rubrum

Fraxinus spp

Ilex opaca

Clethra alnifolia

***

***

Liquidambar styraciflua

Liriodendron tulipifera

***

Rhododendron spp

***

***

\#\#*

***

Platanus occidentalis

Site 14a

overstory

Total

Liquidambar styraciflua

Acer rubrum

Fraxinus spp

Ilex opaca

Quercus alba

Quercus phellos

Quercus palustris
Meter^2/ Relative

Hectare Dom

1.769895

0.26193

0.376991

0.406051

0.333009

0.092677

0.065188

0.025525

0.033772

0.058119

0.03927

0.031809

0.003534

0.019242

0.006676

0.001963

0.014137

0.147992

0.213002

0.229421

0.188152

0.052363

0.036832

0.014422

0.019081

0.032838

0.022188

0.017972

0.001997

0.010872

0.003772

0.001109

0.007988
Density/

Hectare
Relative Percent

Density

Sprouts

Importanc

Values

$\begin{array}{lll}11440 & 1 & 1\end{array}$

$\begin{array}{rrr}2480 & 0.216783 & 0.182388 \\ 1600 & 0.13986 & 0.176431 \\ 1120 & 0.097902 & 0.163661 \\ 1280 & 0.111888 & 0.15002 \\ 2080 & 0.181818 & 0.117091 \\ 560 & 0.048951 & 0.042891 \\ 800 & 0.06993 & 0.042176 \\ 480 & 0.041958 & 0.03052 \\ 160 & 0.013986 & 0.023412 \\ 80 & 0.006993 & 0.01459 \\ 80 & 0.006993 & 0.012483 \\ 240 & 0.020979 & 0.011488 \\ 80 & 0.006993 & 0.008932 \\ 160 & 0.013986 & 0.008879 \\ 160 & 0.013986 & 0.007548 \\ 80 & 0.006993 & 0.00749\end{array}$

Meter^2/ Relative

Density/

Hectare Dom

Hectare

Relative

Percent

Importanc

21.64047

1

5920

1

1

$11.11181 \quad 0.512065$

$\begin{array}{ll}2480 & 0.418919\end{array}$

0.465492

6.3742910 .293746

$1520 \quad 0.256757$

0.275251

$\begin{array}{ll}1.367771 & 0.063031\end{array}$

$1040 \quad 0.175676$

0.119353

$\begin{array}{ll}1.100343 & 0.050707\end{array}$

$\begin{array}{ll}480 & 0.081081\end{array}$

0.065894

$1.255459 \quad 0.057855$

$\begin{array}{ll}240 & 0.040541\end{array}$

0.049198

0.330260 .015219

$80 \quad 0.013514$

0.014366

0.1005310 .004633

$80 \quad 0.013514$

0.009073

*** - unidentified species 
Site \# - 15a

Location (Coordinates) $-36036^{\prime} 00^{\prime \prime} 760^{\prime} 9^{\prime} 30^{\prime \prime}$

Owner and Contact -Union Camp

Nearest Stream -Black (or Chapel) Swamp

River Basin - Blackwater River

NWI Classification -PF01A

Approximate Size of Site - 7 acres

Age of Site - 15

Site 15a

herbaceous

Total

Boehmeria cylindrica

***

Saururus cernuus

***

Impatiens capensis

Campsis radicans

Acer rubrum

Viola spp

***

****

***

Smilax spp

Fraxinus spp

$\begin{array}{rlrrrr}\begin{array}{l}\text { Mean } \\ \text { Cover }\end{array} & \begin{array}{l}\text { Relative } \\ \text { Dom }\end{array} & \begin{array}{l}\text { Density/ } \\ 0.5 \mathrm{~m}^{\wedge} \mathbf{2}\end{array} & \begin{array}{l}\text { Relative } \\ \text { Density }\end{array} & \begin{array}{l}\text { Importanc } \\ \text { Values }\end{array} \\ 25.56667 & & 1 & 42.66667 & 1 & 1 \\ & & & & \\ 6.666667 & 0.260756 & 16.5 & 0.386719 & 0.323737 \\ 2.95 & 0.115385 & 15 & 0.351563 & 0.233474 \\ 9.583333 & 0.374837 & 2.166667 & 0.050781 & 0.212809 \\ 2.933333 & 0.114733 & 3.5 & 0.082031 & 0.098382 \\ 0.416667 & 0.016297 & 1.5 & 0.035156 & 0.025727 \\ 0.833333 & 0.032595 & 0.666667 & 0.015625 & 0.02411 \\ 0.45 & 0.017601 & 1 & 0.023438 & 0.020519 \\ 0.433333 & 0.016949 & 0.666667 & 0.015625 & 0.016287 \\ 0.433333 & 0.016949 & 0.666667 & 0.015625 & 0.016287 \\ 0.416667 & 0.016297 & 0.333333 & 0.007813 & 0.012055 \\ 0.416667 & 0.016297 & 0.166667 & 0.003906 & 0.010102 \\ 0.016667 & 0.000652 & 0.333333 & 0.007813 & 0.004232 \\ 0.016667 & 0.000652 & 0.166667 & 0.003906 & 0.002279\end{array}$

*** - unidentified species 
Site 15a

understory

Total

Fraxinus spp

Acer rubrum

Taxodium distichum

Magnolia virginiana

Liquidambar styraciffua

Ilex verticillata

Site 15a

overstory

Total

Fraxinus spp

Nyssa aquatica

Nyssa sylvatica

Acer rubrum

Magnolia virginiana
Meter^2/ Relative Density/ Relative Percent Importanc

Hectare Dom Hectare Density Sprouts Values

$\begin{array}{lrrrrrr}0.866229 & 1 & 4200 & 1 & 0.793651 & 1 \\ & & & & & \\ 0.733038 & 0.846241 & 3000 & 0.714286 & 0.866667 & 0.780263 \\ 0.053014 & 0.061201 & 400 & 0.095238 & 0.5 & 0.07822 \\ 0.020617 & 0.023801 & 333.3333 & 0.079365 & 0.8 & 0.051583 \\ 0.018653 & 0.021534 & 266.6667 & 0.063492 & 1 & 0.042513 \\ 0.037961 & 0.043823 & 133.3333 & 0.031746 & 0 & 0.037785 \\ 0.002945 & 0.0034 & 66.66667 & 0.015873 & 0 & 0.009637\end{array}$

Meter'2/ Relative Density/ Relative Percent Importanc Hectare Dom Hectare Density Sprouts Values

36.47618

14533.333

10.852941

1

$\begin{array}{llll}17.17535 & 0.470865 & 2733.333 & 0.602941\end{array}$

$\begin{array}{llll}16.20735 & 0.444327 & 933.3333 & 0.205882\end{array}$

$\begin{array}{lllll}1.159771 & 0.031795 & 466.6667 & 0.102941\end{array}$

$\begin{array}{llll}1.84994 & 0.050716 & 333.3333 & 0.073529\end{array}$

$\begin{array}{llll}0.083776 & 0.002297 & 66.66667 & 0.014706\end{array}$
$0.804878 \quad 0.536903$

0.9285710 .325105

10.067368

10.062123

$\begin{array}{ll}0 & 0.008501\end{array}$

*** - unidentified species 
Site \# - 15b

Location (Coordinates) - 36041'50" 77026'00"

Owner and Contact -J.W. Pollard

Nearest Stream - Three Creek

River Basin - Nottoway River

NWI Classification -PF01A

Approximate Size of Site - 82 acres

Age of Site - 15

Site 15b

herbaceous

Total

Ilex opaca

*** - unidentified species

$\begin{array}{rlrrrr}\begin{array}{l}\text { Mean } \\ \text { Cover }\end{array} & \begin{array}{l}\text { Relative } \\ \text { Dom }\end{array} & \begin{array}{l}\text { Density/ } \\ 0.5 \mathrm{~m}^{\wedge} 2\end{array} & \begin{array}{l}\text { Relative } \\ \text { Density }\end{array} & \begin{array}{l}\text { Importanc } \\ \text { Values }\end{array} \\ 0.625 & 1 & 0.25 & 1 & 1 \\ 0.625 & 1 & 0.25 & 1 & 1 \\ & & & & & \end{array}$


Site 15b

understory

Total

Acer rubrum

Fraxinus spp

Quercus laurifolia

***

Carpinus caroliniana

***

Quercus lyrata

Platanus occidentalis

Site $15 b$

overstory

Total

Acer rubrum

Fraxinus spp

Salix nigra

Populus heterophylla

Carpinus caroliniana

Quercus laurifolia

Liquidambar styraciflua $\begin{array}{llllll}\text { Meter 2/ } & \text { Relative } & \text { Density/ } & \text { Relative } & \text { Percent } & \text { Importanc } \\ \text { Hectare } & \text { Dom } & \text { Hectare } & \text { Density } & \text { Sprouts } & \text { Values }\end{array}$

1.665044

17300

1

0

1

$\begin{array}{lr}0.793743 & 0.47671 \\ 0.330358 & 0.198408 \\ 0.032398 & 0.019458 \\ 0.251818 & 0.151238 \\ 0.239546 & 0.143868 \\ 0.004418 & 0.002653 \\ 0.008345 & 0.005012 \\ 0.004418 & 0.002653\end{array}$

$\begin{array}{rr}3600 & 0.493151 \\ 1200 & 0.164384 \\ 300 & 0.041096 \\ 800 & 0.109589 \\ 1000 & 0.136986 \\ 100 & 0.013699 \\ 200 & 0.027397 \\ 100 & 0.013699\end{array}$

$\begin{array}{ll}0.166667 & 0.48493\end{array}$

0.0833330 .181396

$\begin{array}{ll}0 & 0.030277\end{array}$

$\begin{array}{ll}0.125 & 0.130414\end{array}$

$\begin{array}{ll}0 & 0.140427\end{array}$

$\begin{array}{ll}0 & 0.008176\end{array}$

$\begin{array}{ll}0 & 0.016205\end{array}$

o 0.008176

***

Meter^2/ Relative

Hectare

Dom

Density/

Hectare

Relative

Percent Importanc

31.4174

8300

$1 \quad 0.39759$

1

5.7363520 .182585

$5.838454 \quad 0.185835$

$10.57588 \quad 0.336625$

$4.635322 \quad 0.14754$

$\begin{array}{lll}0.887009 & 0.028233\end{array}$

$\begin{array}{ll}1.573742 & 0.050091\end{array}$

$\begin{array}{lll}1.89281 & 0.060247\end{array}$

0.2778350 .008843

$\begin{array}{rr}2700 & 0.325301 \\ 2300 & 0.277108 \\ 900 & 0.108434 \\ 300 & 0.036145 \\ 900 & 0.108434 \\ 700 & 0.084337 \\ 200 & 0.024096 \\ 300 & 0.036145\end{array}$

$\begin{array}{lll}0.481481 & 0.253943\end{array}$

$\begin{array}{lll}0.391304 & 0.231472\end{array}$

$\begin{array}{lll}0.444444 & 0.222529\end{array}$

$\begin{array}{ll}0 & 0.091842\end{array}$

$\begin{array}{lll}0.777778 & 0.068333\end{array}$

$\begin{array}{ll}0 & 0.067214\end{array}$

$\begin{array}{ll}0 & 0.042172\end{array}$

$\begin{array}{ll}0 & 0.022494\end{array}$

*** - unidentified species 
Site \# -17a

Location (Coordinates) $-36048^{\prime} 00^{\prime \prime} \quad 76055^{\prime} 00^{\prime \prime}$

Owner and Contact - Rose Estate

Nearest Stream - Black Creek Swamp

River Basin - Blackwater River

NWI Classification - PF01E

Approximate Size of Site - 15 acres

Age of Site - 17

Site 17a

herbaceous

Total

Murdania keisak

Eleocharis spp

Saururus cernuus

***

Hypericum walteri

Acer rubrum

Polygonum punctatum

Hypericum virginicum

Lycopus virginicus

Toxicodendron radicans

Boehmeria cylindrica

Woodwardia areolata

***

Zizania aquatica

***

***

***

Smilax spp

Salix nigra

Taxodium distichum

Nyssa sylvatica

\begin{tabular}{|c|c|c|c|c|}
\hline $\begin{array}{l}\text { Mean } \\
\text { Cover }\end{array}$ & $\begin{array}{l}\text { Relative } \\
\text { Dom }\end{array}$ & $\begin{array}{l}\text { Density/ } \\
0.5 \mathrm{~m}^{\wedge} 2\end{array}$ & $\begin{array}{l}\text { Relative } \\
\text { Density }\end{array}$ & $\begin{array}{l}\text { Importanc } \\
\text { Values }\end{array}$ \\
\hline 55.61667 & 1 & 131.3333 & 1 & 1 \\
\hline 35.83333 & 0.644291 & 78.83333 & 0.600254 & 0.622273 \\
\hline 2.5 & 0.044951 & 26 & 0.19797 & 0.12146 \\
\hline 7.5 & 0.134852 & 2.166667 & 0.016497 & 0.075675 \\
\hline 0.416667 & 0.007492 & 14.16667 & 0.107868 & 0.05768 \\
\hline 2.516667 & 0.04525 & 0.666667 & 0.005076 & 0.025163 \\
\hline 2.5 & 0.044951 & 0.666667 & 0.005076 & 0.025013 \\
\hline 0.433333 & 0.007791 & 2.666667 & 0.020305 & 0.014048 \\
\hline 0.85 & 0.015283 & 1.666667 & 0.01269 & 0.013987 \\
\hline 0.833333 & 0.014984 & 0.5 & 0.003807 & 0.009395 \\
\hline 0.416667 & 0.007492 & 0.833333 & 0.006345 & 0.006918 \\
\hline 0.433333 & 0.007791 & 0.666667 & 0.005076 & 0.006434 \\
\hline 0.416667 & 0.007492 & 0.5 & 0.003807 & 0.005649 \\
\hline 0.416667 & 0.007492 & 0.333333 & 0.002538 & 0.005015 \\
\hline 0.416667 & 0.007492 & 0.166667 & 0.001269 & 0.00438 \\
\hline 0.033333 & 0.000599 & 0.333333 & 0.002538 & 0.001569 \\
\hline 0.016667 & 0.0003 & 0.333333 & 0.002538 & 0.001419 \\
\hline 0.016667 & 0.0003 & 0.166667 & 0.001269 & 0.000784 \\
\hline 0.016667 & 0.0003 & 0.166667 & 0.001269 & 0.000784 \\
\hline 0.016667 & 0.0003 & 0.166667 & 0.001269 & 0.000784 \\
\hline 0.016667 & 0.0003 & 0.166667 & 0.001269 & 0.000784 \\
\hline 0.016667 & 0.0003 & 0.166667 & 0.001269 & 0.000784 \\
\hline
\end{tabular}

*** - unidentified species 
Site 17a

understory

Total

Taxodium distichum

Acer rubrum

Viburnum nudum

Alnus serrulata

Clethra alnifolia

Toxicodendron radicans

Platanus occidentalis

Ilex glabra

Fraxinus spp

Clethra alnifolia

Leucothoe racemosa

Liquidambar styraciflua

Nyssa sylvatica

Salix nigra

Nyssa aquatica
Meter^2/ Relative

Hectare Dom

2.718787

1.444151

0.342303

0.164279

0.160352

0.05825

0.081812

0.095884

0.100138

0.049415

0.034688

0.069377

0.050724

0.040906

0.016035

0.010472

Meter^2/ Relative

Hectare

Dom

20.36014

$1 \quad 3133.333$

11.79341

1.213113

2.453388

0.778526

0.852484

1.840777

1.217694

0.1309

0.047124

0.032725
0.57924

0.059583

0.1205

0.038238

0.04187

0.090411

0.059808

0.006429

0.002315

0.001607
Density/ Relative

Hectare Density

Percent

Sprouts

Importanc

Values

\begin{tabular}{|rr}
0.518241 & 1 \\
0.677083 & 0.478921 \\
0.214286 & 0.094062 \\
0.52381 & 0.076879 \\
0.941176 & 0.067267 \\
0 & 0.044046 \\
0 & 0.043935 \\
0.6 & 0.028745 \\
0 & 0.027305 \\
0.625 & 0.026865 \\
0 & 0.026379 \\
0 & 0.026092 \\
0 & 0.024884 \\
0 & 0.01419 \\
0 & 0.01406 \\
0 & 0.00637
\end{tabular}

Liriodendron tulipifera

Alnus serrulata

\begin{tabular}{rr}
\hline 733.3333 & 0.234043 \\
800 & 0.255319 \\
\hline 533.3333 & 0.170213 \\
466.6667 & 0.148936 \\
\hline 266.6667 & 0.085106 \\
66.66667 & 0.021277 \\
66.66667 & 0.021277 \\
66.66667 & 0.021277 \\
\hline 66.66667 & 0.021277 \\
66.66667 & 0.021277
\end{tabular}

$1 \quad 0.595745$

1

$\begin{array}{lll}0.909091 & 0.406641\end{array}$

$0.666667 \quad 0.157451$

0.3750 .145356

$\begin{array}{lll}0.857143 & 0.093587\end{array}$

$\begin{array}{ll}0.25 & 0.063488\end{array}$

$\begin{array}{ll}0 & 0.055844\end{array}$

$\begin{array}{ll}0 & 0.040542\end{array}$

$\begin{array}{ll}0 & 0.013853\end{array}$

$\begin{array}{ll}0 & 0.011796\end{array}$

$\begin{array}{ll}0 & 0.011442\end{array}$

*** - unidentified species 
Site \# - 20a

Location (Coordinates) $-36044^{\prime} 15^{\prime \prime} 76019^{\prime} 00^{\prime \prime}$

Owner and Contact - Jack W. Vick

Nearest Stream - Three Creek

River Basin - Nottoway River

NWI Classification -PF01A

Approximate Size of Site -

Age of Site - 20

Site 20a

herbaceous

Total

Arundinaria gigantea

Acer rubrum

Smilax spp

Saururus cernuus

Campsis radicans

Fraxinus spp

\begin{tabular}{rlrrrr}
$\begin{array}{l}\text { Mean } \\
\text { Cover }\end{array}$ & $\begin{array}{l}\text { Relative } \\
\text { Dom }\end{array}$ & $\begin{array}{l}\text { Density/ } \\
0.5 \mathrm{~m}^{\wedge} 2\end{array}$ & $\begin{array}{l}\text { Relative } \\
\text { Density }\end{array}$ & \multicolumn{1}{l}{$\begin{array}{l}\text { Importanc } \\
\text { Values }\end{array}$} \\
3.985714 & 1 & 4.571429 & 1 & 1 \\
& & & & \\
2.5 & 0.62724 & 2.142857 & 0.46875 & 0.547995 \\
0.371429 & 0.09319 & 1 & 0.21875 & 0.15597 \\
0.042857 & 0.010753 & 1 & 0.21875 & 0.114751 \\
0.357143 & 0.089606 & 0.285714 & 0.0625 & 0.076053 \\
0.357143 & 0.089606 & 0.142857 & 0.03125 & 0.060428 \\
0.357143 & 0.089606 & 0 & 0 & 0.044803
\end{tabular}

*** - unidentified species 
Site 20a

understory

Total

Acer rubrum

Quercus lyrata

Fraxinus spp

Cornus stricta

Quercus laurifolia $\begin{array}{llllll}\text { Meter^2/ } & \text { Relative } & \text { Density/ } & \text { Relative } & \text { Percent } & \text { Importanc } \\ \text { Hectare } & \text { Dom } & \text { Hectare } & \text { Density } & \text { Sprouts } & \text { Values }\end{array}$

0.490874

$\begin{array}{ll}1 & 1542.857\end{array}$

$\begin{array}{ll}1 & 0.481481\end{array}$

1

$0.243754 \quad 0.496571$

$0.102382 \quad 0.208571$

$685.7143 \quad 0.444444$

$\begin{array}{ll}400 & 0.259259\end{array}$

$0.833333 \quad 0.470508$

$\begin{array}{lllll}0.095089 & 0.193714 & 285.7143 & 0.185185\end{array}$

$\begin{array}{ll}0 & 0.233915\end{array}$

$\begin{array}{llllll}0.031696 & 0.064571 & 114.2857 & 0.074074\end{array}$

$\begin{array}{llll}0.017952 & 0.036571 & 57.14286 & 0.037037\end{array}$

$\begin{array}{ll}0.4 & 0.18945\end{array}$

$\begin{array}{ll}0.5 & 0.069323\end{array}$

o 0.036804

\author{
Site 20a \\ overstory \\ Total \\ Salix nigra \\ Acer rubrum \\ Liquidambar styraciflua \\ Populus heterophylla \\ Quercus lyrata \\ Betula nigra \\ Fraxinus spp \\ Ulmus americana \\ Quercus laurifolia
}

$\begin{array}{llllll}\text { Meter^2/ } & \text { Relative } & \text { Density/ } & \text { Relative } & \text { Percent } & \text { Importanc } \\ \text { Hectare } & \text { Dom } & \text { Hectare } & \text { Density } & \text { Sprouts } & \text { Values }\end{array}$

$\begin{array}{ll}1 & 3942.857\end{array}$

$\begin{array}{ll}1 & 0.362319\end{array}$

1

7.38667

2.11216

0.392728

0.112298

0.1076

2.023803

$285.7143 \quad 0.072464$

$\begin{array}{ll}0.6 & 0.232596\end{array}$

$\begin{array}{ll}2.497847 & 0.132803\end{array}$

$0.844023 \quad 0.044874$

$\begin{array}{ll}1.548917 & 0.082352\end{array}$

$\begin{array}{lll}971.4286 & 0.246377\end{array}$

$\begin{array}{lll}514.2857 & 0.130435\end{array}$

0.6470590 .179337

$\begin{array}{lll}285.7143 & 0.072464\end{array}$

$\begin{array}{ll}628.5714 & 0.15942\end{array}$

$\begin{array}{lll}342.8571 & 0.086957\end{array}$

$1.189598 \quad 0.063248$

$1.165194 \quad 0.06195$

$\begin{array}{lll}400 & 0.101449\end{array}$

$400 \quad 0.101449$

0.040392

0.002148

$\begin{array}{lll}114.2857 & 0.028986\end{array}$

$\begin{array}{ll}0 & 0.119017\end{array}$

$\begin{array}{ll}0 & 0.102634\end{array}$

$\begin{array}{lll}0.272727 & 0.102147\end{array}$

$\begin{array}{ll}0 & 0.084654\end{array}$

0.5714290 .082348

$\begin{array}{ll}0.571429 & 0.0817\end{array}$

$\begin{array}{ll}0 & 0.015567\end{array}$

*** - unidentified species 
Site \# - 20b

Location (Coordinates) - 36 $39^{\circ} 41^{\prime \prime} \mathrm{W} 77^{\circ} 28^{\prime} 27^{\prime \prime}$

Owner and Contact - Union Camp (experimental site)

Nearest Stream - Meherrin River

River Basin - Meherrin River

NWI Classification - PFO1A

Approximate Size of Site - 30 acres

Age of Site -20 years

no herbaceous data 
Site 20b

understory

Total

Acer rubrum

Fraxinus spp

Ostrya virginiana

Site 20b

overstory

Total

Acer rubrum

Fraxinus spp

Liquidambar styraciflua

Salix nigra

T2-20b2

Quercus lyrata

T2-20b1 $\begin{array}{llllll}\text { Meter^2/ } & \text { Relative } & \text { Density/ } & \text { Relative } & \text { Percent } & \text { Importanc } \\ \text { Hectare } & \text { Dom } & \text { Hectare } & \text { Density } & \text { Sprouts } & \text { Values }\end{array}$

$\begin{array}{llllll}0.138623 & 1 & 1600 & 1 & 0.75 & 1\end{array}$

$\begin{array}{llllll}0.118988 & 0.858357 & 640 & 0.4 & 0.75 & 0.629178\end{array}$

$\begin{array}{llllll}0.009817 & 0.070822 & 880 & 0.55 & 1 & 0.310411\end{array}$

$\begin{array}{llllll}0.009817 & 0.070822 & 80 & 0.05 & 0 & 0.060411\end{array}$

Meter 2/ Relative Density/ Relative Percent Importanc Hectare Dom Hectare Density Sprouts Values

$\begin{array}{llllll}35.27969 & 1 & 4400 & 1 & 0.654545 & 1\end{array}$

$\begin{array}{llllll}15.67262 & 0.444239 & 2400 & 0.545455 & 0.633333 & 0.494847\end{array}$

$\begin{array}{llllll}8.862433 & 0.251205 & 1360 & 0.309091 & 0.882353 & 0.280148\end{array}$

$\begin{array}{lllllll}6.031072 & 0.17095 & 240 & 0.054545 & 0.666667 & 0.112748\end{array}$

$\begin{array}{lllllll}3.771875 & 0.106913 & \cdot & 160 & 0.036364 & 0 & 0.071639\end{array}$

$\begin{array}{llllll}0.567057 & 0.016073 & 80 & 0.018182 & 0 & 0.017128\end{array}$

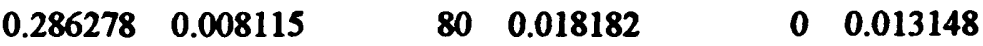

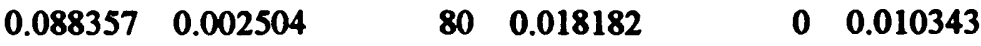


Vita

\section{David Randolph Spencer}

Born in San Francisco, California, on February 7, 1970. Graduated from Chapin High School in Chapin, South Carolina, in 1988. Earned a Bachelor of Science in Criminal Justice from Appalachian State University in December of 1991. Following the completion of a cooperative position with the National Marine Fisheries Service in Charleston, South Carolina, entered the master's program at the College of William and Mary, School of Marine Science in 1994. Currently employed as the Water Resources Coordinator for the Southeast Region of the National Park Service. 